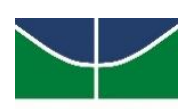

\title{
UnB
}

UNIVERSIDADE DE BRASÍLIA - UnB

Centro de Excelência em Turismo

Programa de Mestrado Profissional

\section{EDUCAÇÃO PATRIMONIAL E A FORMAÇÃO DO TURISTA CIDADÃO: UM ESTUDO DE CASO SOBRE O PROJETO RE(VI)VENDO ÊXODOS}

Fernanda da Silva Sant'Anna

Brasília - 2015 


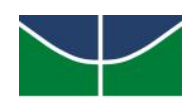

\section{UnB}

UNIVERSIDADE DE BRASÍLIA - UnB

Centro de Excelência em Turismo

Programa de Mestrado Profissional

\section{EDUCAÇÃO PATRIMONIAL E A FORMAÇÃO DO TURISTA CIDADÃO: UM ESTUDO DE CASO SOBRE O PROJETO RE(VI)VENDO ÊXODOS}

Fernanda da Silva Sant'Anna

Dissertação de Mestrado apresentada ao Mestrado Profissional em Turismo da Universidade de Brasília - UnB, como parte dos requisitos para obtenção do título de Mestre em Turismo. Linha de Pesquisa: Cultura e Sustentabilidade no Turismo.

Orientação: Prof ${ }^{a}$. Dra ${ }^{a}$. Eloísa Pereira Barroso 
Ficha catalográfica elaborada automaticamente, com os dados fornecidos pelo(a) autor(a)

da Silva Sant'Anna, Fernanda EDUCAÇÃO PATRIMONIAL E A FORMAÇÃO DO TURISTA CIDADÃO: UM ESTUDO DE CASO SOBRE O PROJETO RE(VI) VENDO ÊXODOS / Fernanda da Silva Sant'Anna; orientador Eloisa Pereira Barroso. -- Brasilia, 2015. $131 \mathrm{p}$.

Dissertação (Mestrado - Mestrado Profissional em Turismo) -- Universidade de Brasilia, 2015.

1. Educação Patrimonial. 2. Experiência. 3. Projeto Re(vi) vendo Êxodos. 4. Turismo. 5. Turista Cidadão. I. Pereira Barroso, Eloísa, orient. II. Título. 


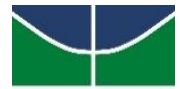 \\ UnB \\ UNIVERSIDADE DE BRASÍLIA - UnB \\ Centro de Excelência em Turismo \\ Programa de Mestrado Profissional}

Dissertação de Mestrado submetida à Banca Examinadora designada pelo Colegiado do Programa de Pós-Graduação em Turismo da Universidade de Brasília - UnB, como parte dos requisitos para obtenção do título de Mestre em Turismo. Linha de Pesquisa: Cultura e Sustentabilidade no Turismo.

Fernanda da Silva Sant'Anna

Aprovado por:

Prof $^{\mathrm{a}}$. Dr ${ }^{\mathrm{a}}$. Eloísa Pereira Barroso (Orientadora)

Universidade de Brasília - CET/ UnB

Pof $^{\mathrm{a}}$. Dra ${ }^{\mathrm{a}}$. Karina e Silva Dias (Avaliador externo)

Universidade de Brasília - CET/ UnB

Prof $^{\mathrm{a}}$. Dr ${ }^{\mathrm{a}}$. Neuza de Farias Araújo (Avaliador interno)

Universidade de Brasília - CET/UnB

Brasília, 04 de março de 2015. 
Àqueles que, por meio das diversas experiências compartilhadas - família, amigos, professores, colegas, conhecidos ou apenas errantes no caminho que percorri até aqui, me ajudaram e, ainda ajudam, a construir e ressignificar minha identidade. 


\section{AGRADECIMENTOS}

- A Prof. ${ }^{a}$ Dr. ${ }^{a}$ Eloísa Pereira Barroso pela orientação e fundamentais contribuições acadêmicas;

- Ao Professor Luís Guilherme pela abertura e apoio na pesquisa de campo e gabinete, o que tornou a busca aos materiais produzidos pelos alunos do Projeto $\operatorname{Re}($ vi)vendo Êxodos prazerosa e acessível;

- Aos entrevistados Bárbara Costa, Elizabeth Pazello, Francisco Vladimir Almeida, Hérisson Duarte, João Carlos Mendes, Júlia Ouriques, Pedro Victor Sousa e Rafael Gomes pela colaboração e valiosos depoimentos;

- A Prof. ${ }^{a}$ Sônia Rampim Florêncio por ser fonte inspiradora desde a graduação em Turismo;

- Aos Professores do Mestrado Profissional em Turismo do Centro de Excelência em Turismo da Universidade de Brasília - CET UNB, pelas contribuições dadas dentro de suas respectivas áreas;

- Às amigas Andressa Duarte, Cátia Almeida, Déborah Mendes, Enaide Cordeiro e Silvana Lopes pelo apoio e compreensão nos momentos necessários;

- Aos meus pais Lourenço e Eva, e a minha irmã Adriana pelo incentivo e amor incondicional;

- À Rogério Galeno, amigo e companheiro de leituras e compartilhamento de experiências inestimáveis. 
O mundo é aquilo que nós percebemos. [...] $\mathrm{O}$ mundo é não aquilo que eu penso, mas aquilo que eu vivo; Eu estou aberto ao mundo, comunico-me indubitavelmente com ele, Mas não o possuo, ele é inesgotável. Merleau-Ponty. 


\section{RESUMO}

O Projeto Re(vi)vendo Êxodos se caracteriza pelo ensino e orientação de jovens no contexto de três áreas específicas que são: Cidadania, Patrimônio e Qualidade de Vida. O presente projeto de pesquisa se propõe a analisar o Projeto $\operatorname{Re}(v i) v e n d o$ Exxodos a partir da Educação Patrimonial como conscientizador do educando quanto à importância da valorização de sua cultura e, ainda, como incentivo à prática responsável de preservação do Patrimônio permitindo que o cidadão aprenda a enxergar a sua cidade de maneira diferenciada, levando à construção e prática de um novo olhar e, consequentemente, ao surgimento do Turista Cidadão. Com o intuito de esclarecer esta perspectiva a presente dissertação traz uma análise dos conceitos do Fenômeno Turístico que podem ser utilizados para compreender a importância da Educação Patrimonial para este fenômeno. As acepções acerca das categorias Experiência e Educação propostas por autores específicos, também serão analisadas em relação à vivência sociocultural dos alunos participantes do Projeto Re(vi)vendo Êxodos.

Palavras-chave: Educação Patrimonial. Experiência. Projeto $\operatorname{Re}(v i) v e n d o$ Êxodos. Turismo. Turista Cidadão. 


\begin{abstract}
The Re(vi)vendo Exxodos Project is characterized by the teaching and guidance of young people in three specific areas that are: Citizenship, Heritage and Life Quality. This research project aims to analyze the $\operatorname{Re}(v i) v e n d o$ Exodos Project based on heritage education as conscientizing of educating on the importance of valuing their culture and also as an incentive to practice responsible conservation Heritage allowing citizens learn to understand their city differently, leading to the construction and practice of a new perspective and, consequently, the appearance of Tourist Citizen. Craving clarify this perspective this dissertation presents an analysis of the concepts of the Tourism Phenomenon that can be used to understand the importance of heritage education for this phenomenon. The meanings of the categories Experience and Education proposals for specific authors, will also be analyzed in relation to socio-cultural experience of students participating at the $\operatorname{Re}(v i)$ vendo Exxodos Project.
\end{abstract}

Keywords: Heritage Education. Experience. Re(vi)vendo Êxodos Project. Tourism. Tourist Citizen. 


\section{LISTA DE ILUSTRAÇÕES}

Figura 1: Fotografia de Sebastião Salgado exibida na exposição "Êxodos"

Figura 2: Manifestantes do MST (Movimento dos Sem Terra) em frente à Esplanada dos Ministérios - Brasília, 20 de junho de 2001

Figura 3: Imagem representativa dos pontos cardeais da Rosa dos Ventos. Capa do Cartaz de Divulgação e dos convites da primeira Exposição Re(vi)vendo Êxodos Brasília, 20 de junho de 2001

Figura 4: Relato da aluna Matilde do Centro de Ensino Médio da Asa Norte sobre pesquisa de campo feita em Pirenópolis - GO pelo Projeto Re(vi)vendo Êxodos no ano de 2014.

Figura 5: Sarau - Comemoração dos 11 anos do Projeto Re(vi)vendo Êxodos, 2012 ..68

Figura 6: Vista noturna da Ponte JK - Lago Paranoá - Fotografia tirada por alunos do Re(vi)vendo Êxodos, 2013

Figura 7: Caminhada Re(vi)vendo Êxodos - Fotografia tirada por monitores do Re(vi)vendo Êxodos, 2010

Figura 8: Pesquisa de campo à cidade de Santa Isabel (GO) - Fotografia tirada por monitores do Re(vi)vendo Êxodos, 2011

Figura 9: Caminhada Re(vi)vendo Êxodos - Fotografia tirada por monitores do Projeto, 2006.

Figura 10: Caminhada - As bandeiras de cores diferentes representam a divisão dos alunos em equipes. Cada equipe é responsável por apresentar um relatório que contenha o registro da "memória" de cada dia da caminhada

Figura 11: Caminhada 2010 - Fotografias tiradas pelos participantes do $\operatorname{Re}(v i) v e n d o$ Exodos 


\section{SUMÁRIO}

\section{INTRODUÇÃO}

1. TURISMO, EDUCAÇÃO e IDENTIDADE CULTURAL ................................18

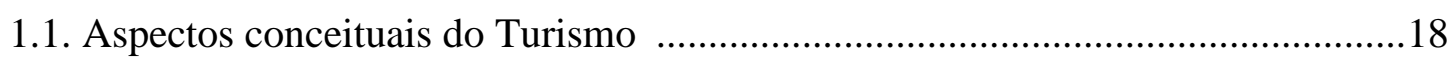

1.2. Experiência e Educação ...............................................................................2 23

1.3. A Educação Patrimonial e a Formação da Identidade do Turista Cidadão............27

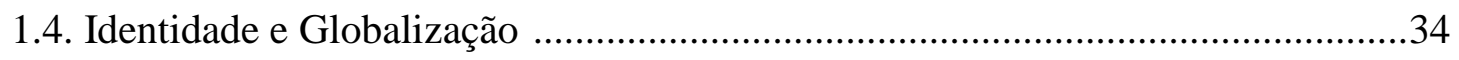

2. O PROJETO RE(VI)VENDO ÊXODOS ..........................................................42

2.1. Referências Históricas .................................................................................42

2.1. Limitações Enfrentadas pelo Projeto ...............................................................48

\section{EXPERIÊNCIAS DO ÊXODOS NA FORMAÇÃO DO TURISTA CIDADÃO 51}

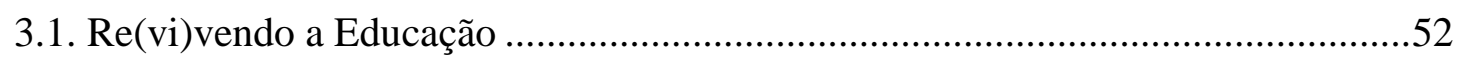

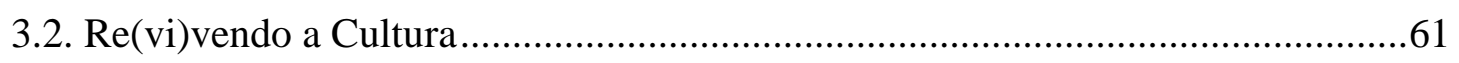

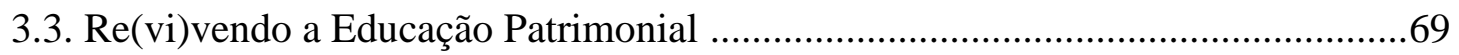

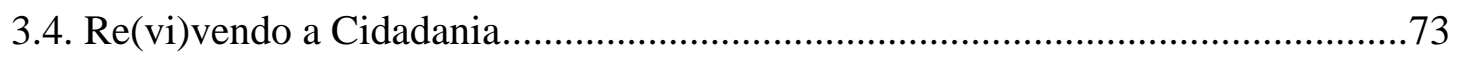

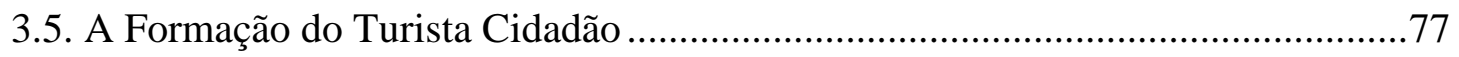

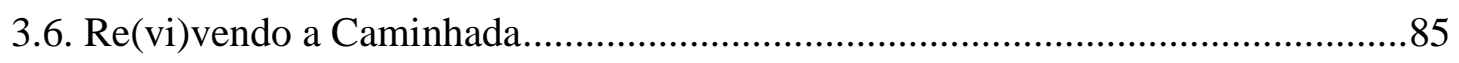

CONSIDERAÇÕES FINAIS ........................................................................102

REFERÊNCIAS BIBLIOGRÁFICAS...........................................................106

APÊNDICES .............................................................................................112

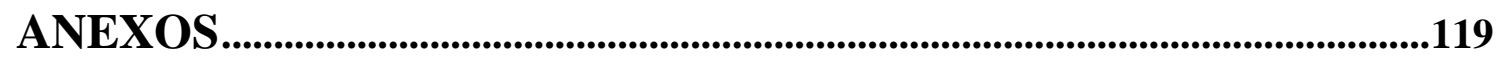




\section{INTRODUÇÃO}

A pesquisa proposta busca acompanhar o processo de formação do Turista Cidadão a partir da análise do projeto escolar Re(vi)vendo Êxodos, cujas atividades desenvolvidas, tendo relação direta com a educação patrimonial, se mostram capazes de auxiliar no desenvolvimento do cidadão.

O $\operatorname{Re}(v i) v e n d o$ Exxodos é um projeto cultural-pedagógico que tem como propósito levar para os alunos da rede pública, uma formação intelectual e emocional que possibilite a transformação de todos em cidadãos críticos, participativos e sensíveis. Este projeto tem sido desenvolvido desde o ano de 2001 por professores da rede pública e pelo professor, idealizador e coordenador do projeto Luís Guilherme Baptista ${ }^{1}$.

Atualmente, o Re(vi)vendo Êxodos atua nas escolas Centro de Ensino Médio Setor Leste, Centro Educacional do Lago, Centro Educacional da Asa Norte e na Escola Nova Betânia, em São Sebastião, com possibilidades de expansão para outras escolas públicas do Distrito Federal.

Desde o ano de 2007 as atividades propostas pelo projeto eram embasadas nas áreas de atuação Patrimônio, Identidade e Meio Ambiente. Contudo, com o intuito de renovar um pouco o projeto e acreditando que as questões de Identidade e Meio Ambiente já estão inseridas através de outras disciplinas e atividades pedagógicas, o coordenador Luís Guilherme decidiu substituí-las por duas novas áreas de atuação: Cidadania e Qualidade de Vida, mantendo a área Patrimônio.

O intuito do professor com essa renovação é fazer com que a partir da compreensão por parte dos alunos de que preservar o patrimônio é uma ação cidadã e, ainda, traz qualidade de vida, acabará inserindo naturalmente a valorização deste patrimônio como consequência da busca pela cidadania e qualidade de vida. Além disso, mantendo a questão patrimonial o projeto não exclui as questões de identidade e meio ambiente. No caso deste último, relacionando-o ao patrimônio natural.

\footnotetext{
${ }^{1} \mathrm{O}$ coordenador do $\mathrm{Re}(\mathrm{vi})$ vendo Êxodos é, também, professor e ministra a disciplina de História para os alunos dos $2^{\circ} \mathrm{s}$ e $3^{\circ} \mathrm{s}$ anos do Ensino Médio do Centro de Ensino Médio Setor Leste em Brasília Distrito Federal.
} 
Com o intuito de compreender minuciosamente os principais elementos desta pesquisa - o Projeto Re(vi)vendo Êxodos, a Educação Patrimonial e o Turista Cidadão, e considerando que estes se tratam de fatores que auxiliam o entendimento de uma maneira consciente da prática do Turismo, será utilizado como base fundamentos teóricos acerca do fenômeno turístico. Desta forma, considerando que a pesquisa realizada está diretamente ligada às questões socioculturais, a abordagem utilizada tomará por embasamento o foco social e cultural do fenômeno turístico.

A proposta deste projeto de pesquisa ao analisar o $\operatorname{Re}(v i) v e n d o$ Exxodos não é abranger toda a sua complexidade. Uma vez que o projeto vai além da Educação Patrimonial. Considerando que aborda, também, questões de identidade, meio ambiente, cidadania e qualidade de vida, busca-se analisá-lo, a partir da realidade vivenciada pelos participantes, como um possível conscientizador das questões de cidadania e possível formador de Turistas Cidadãos.

Tendo este trabalho acadêmico o intuito de mostrar como se dá o processo de formação do Turista Cidadão a partir da experiência vivida pelo indivíduo em projeto específico de Educação Patrimonial, propõe-se a seguinte hipótese de pesquisa: $\mathrm{O}$ sujeito que vivencia práticas incentivadas e propostas pela educação patrimonial é capaz tanto de apreender dinamicamente, como de praticar o Turismo de forma cidadã.

Uma das perspectivas desta dissertação é fazer esta ligação entre a formação do Turista Cidadão a partir da Educação Patrimonial vivenciada pelos alunos participantes do Projeto Re(vi)vendo Êxodos com base em conceitos voltados para a experiência apresentados por autores como Edward Palmer Thompson, Maurice Merleau-Ponty e John Dewey.

Thompson trabalha o conceito de experiência propondo que é a partir da experiência histórica dos indivíduos que ocorrem as mudanças sociais e culturais. Merleau-Ponty vê a experiência como o caminho que leva em direção ao ambiente físico e social. Dewey trata da experiência como um fator inerente à vida. 
O intuito é analisar, a partir destes conceitos propostos, como a experiência vivida, mediante o processo de Educação Patrimonial, auxilia na formação do Turista Cidadão.

Sobre o conceito de Turista Cidadão, tem-se o intuito de aprofundar a discussão quanto ao significado do termo apresentado pelas autoras precursoras, Susana Gastal e Marutschka Martini Moesch, uma vez que este foi apenas introduzido em seu livro Turismo, Políticas Públicas e Cidadania.

Considerando os aspectos teóricos introduzidos, o objetivo geral desta pesquisa é analisar em que medida a Educação Patrimonial proposta pelo Projeto $\operatorname{Re}($ vi)vendo Êxodos pode contribuir para a formação do Turista Cidadão.

Com isto, pretende-se, com o intuito de se alcançar o objetivo geral proposto, mediante a metodologia escolhida, analisar o projeto $\mathrm{Re}(\mathrm{vi})$ vendo Êxodos na escola onde este surgiu: o Centro de Ensino Médio Setor Leste, como exemplo de projeto de Educação Patrimonial; identificar, durante as diferentes fases do $\operatorname{Re}(v i) v e n d o$ Exxodos (segundo e terceiro ano letivo), como os alunos participantes compreendem a Educação Patrimonial; investigar de que maneira a experiência da prática vivida e a perspectiva do olhar dos participantes do Re(vi)vendo Êxodos se relaciona ao conceito de cidadania; e, ainda, verificar se os participantes do projeto Re(vi)vendo Êxodos adquirem práticas pertinentes ao Turismo Cidadão.

Durante as fases do projeto $\operatorname{Re}(v i) v e n d o$ Êxodos, que será o foco de análise desta pesquisa, os alunos participantes fazem visitas de campo em cidades estudadas previamente em sala de aula. Uma das perspectivas deste projeto de pesquisa se trata de analisar como ocorre o encontro entre a teoria apreendida em sala e a experiência vivida pelos estudantes durante as visitas técnicas.

Por se tratar de uma pesquisa do tipo qualitativa que possui nível de profundidade exploratória e explicativa, compreendeu-se como melhor alternativa utilizar, como quadro interpretativo, a fenomenologia. 
Considerando que a fenomenologia é “(...) um relato do espaço, do tempo, do mundo 'vividos', (...) a tentativa de uma descrição direta de nossa experiência tal como ela é (...)”. (MERLEAU-PONTY, 1999, Pg. 01), enxerga-se na fenomenologia a alternativa ideal para descrever da forma mais fidedigna possível a experiência vivida pelos participantes do Projeto Re(vi)vendo Êxodos.

A fenomenologia, sendo considerada mediante a obra de Merleau-Ponty, possibilita a análise das experiências do homem a partir da consciência de que o mundo existe antes da reflexão.

É preciso, primeiramente, se dar conta de que a existência do mundo antecede qualquer análise que se possa fazer em relação a ele e, da mesma forma, todas as relações e experiências são constituídas a partir de sua existência. Desta forma, "o real deve ser descrito, não construído ou constituído". (MERLEAU-PONTY, 1999, p. 05).

A fenomenologia busca investigar os fenômenos através da análise da experiência em relação a estes fenômenos.

Considera-se também, de acordo com Paul Bruyne, que o processo da fenomenologia se baseia em tentar descrever efetivamente e não explicar as situações vividas pelo sujeito. Tenta-se, com isto, "voltar às próprias coisas", uma vez que, a pesquisa fenomenológica funda-se sobre o vivido e se esforça para recuperar num plano temático o real mais íntimo de determinada vivência. (BRUYNE, 1991).

Levando em consideração que a história oral é "um recurso moderno usado para elaboração de registros, documentos, arquivamento e estudos referentes à experiência social de pessoas e de grupos” (HOLANDA, MEIHY, 2007, p. 17) (Grifo nosso), considerou-se que este se tratava do modo de investigação mais adequado e que melhor auxiliaria no alcance de resultados fundamentalmente fenomenológicos neste estudo de caso.

As técnicas de coleta utilizadas foram, além da entrevista, a pesquisa documental. $\mathrm{O}$ fato de as entrevistas realizadas na perspectiva da história oral serem gravadas auxilia na proximidade de exatidão na descrição dos relatos. 
Realizou-se uma entrevista com o professor Luís Guilherme, coordenador do Re(vi)vendo Êxodos. Foram feitas entrevistas com quatro alunos participantes do Projeto. A escolha feita seguiu o seguinte padrão: dois alunos que estão cursando o primeiro ano do projeto ( $2^{\circ}$ ano do Ensino Médio) e dois alunos que estão no segundo ano do projeto ( $3^{\circ}$ ano do Ensino Médio). Além disso, foram feitas entrevistas com quatro atuais monitores do projeto que, em primeiro momento, foram alunos participantes do Re(vi)vendo Êxodos.

A entrevista realizada com o professor Luís Guilherme foi a primeira delas, ocorreu no dia 04 de junho de 2014, começando às 15:41 tendo duração de 54 minutos. A entrevista realizada em dupla com os alunos do $2^{\circ}$ ano do Ensino Médio (Francisco Vladimir Almeida e Hérisson Duarte) teve início às 09h59min tendo 30 minutos de duração; a entrevista realizada, também em dupla, com as alunas do $3^{\circ}$ ano do Ensino Médio (Bárbara Costa e Júlia Ouriques) teve início às 10h34min tendo 41 minutos de duração. As duas entrevistas foram realizadas no dia 21 de outubro de 2014 no Centro de Ensino Médio Setor Leste - CEM Setor Leste. As entrevistas feitas com os monitores (Elizabeth Pazello, João Carlos Mendes, Pedro Victor Sousa e Rafael Gomes) duraram 3h23min e foram realizadas no dia 04 de novembro de 2014 às 14:57 na Universidade de Brasília - UnB.

O intuito desta seleção foi averiguar as diferenças entre os três perfis e o processo de mudança durante os dois anos que participam do projeto e a fase de monitoria, uma vez que, o tempo disponível para a realização da pesquisa não é suficiente para acompanhamento dos mesmos alunos durante todas as fases do projeto.

Busca-se encontrar, com as entrevistas através da história oral, os aspectos da vida dos participantes do Re(vi)vendo Êxodos a partir de suas experiências individuais, contudo, sempre relacionando estas experiências pessoais à atualidade social, uma vez que:

[...] não existe indivíduo sem sociedade, nem sociedade sem indivíduos [...] uma e outra são produtos e fatores de uma situação única - vida social - e que essa situação por isso mesmo que é o resultado de uma constante interação de elementos diversos, é essencialmente móvel e dinâmica. (DEWEY, 1967, P.28). 
A pesquisa documental foi feita aos materiais fornecidos pelo coordenador do projeto $\operatorname{Re}(v i) v e n d o$ Exxodos, Luís Guilherme Baptista. O conjunto de materiais disponíveis para esta pesquisa são produções dos próprios alunos participantes do projeto desde o ano de sua primeira edição, em 2001 e engloba mais de seis mil fotografias, poemas, portfólios, resultados de pesquisas, entre outros possíveis objetos de análise.

A partir dos fatores apresentados espera-se, ainda, mostrar que o entendimento fenomenológico e conceitual do Turismo pode ser alcançado através da investigação e análise da integração entre as experiências culturais vividas pelos indivíduos e o estudo científico do objeto turístico. 


\section{CAPÍtULO 1:}

\section{TURISMO, EDUCAÇÃO E IDENTIDADE CULTURAL}

\section{1 - Aspectos Conceituais do Turismo}

Por se tratar de um fenômeno socioeconômico relativamente jovem e que possui características multidisciplinares, ou seja, que engloba distintas disciplinas acadêmicas há uma dificuldade para se formular conceitos que definam o que é, de fato, o fenômeno turístico. Entretanto, desde meados do século XX, são elaboradas acepções a respeito do Turismo, cada uma delas destacando diferentes aspectos deste fenômeno ou ainda, os mesmos aspectos, porém utilizando bases teóricas distintas. Vale destacar que, apesar de haverem diferenças, não se pode afirmar que existem definições corretas ou incorretas, visto que estas, de uma forma ou de outra, contribuem na formulação de novas teorias e na compreensão do fenômeno turístico.

Nesta perspectiva serão apresentadas, inicialmente, algumas concepções que ajudaram e ainda ajudam na construção de outras definições acerca do turismo.

Uma recente definição de Turismo adotada pela Organização Mundial de Turismo - OMT descreve esta prática como "as atividades que as pessoas realizam durante viagens e estadas em lugares diferentes do seu entorno habitual, por um período inferior a um ano, com finalidade de lazer, negócios ou outras.” (OMT, apud MTur).

O conceito usado pela OMT relaciona o Turismo com todas as práticas realizadas pelo turista durante uma viagem, e não apenas com a permanência no local. Além disso, delimita o período de estada na localidade, deixando uma linha tênue de separação entre a atividade turística e a residência.

Em 1942, Walter Hunziker e Kurt Krapf definiram que turismo é:

O conjunto das relações e dos fenômenos produzidos pelo deslocamento e permanência de pessoas fora do seu local de domicílio, sempre que ditos deslocamento e permanência não estejam motivados por uma atividade lucrativa. (HUNZIKER e KRAPF, apud MONTEJANO, 2001) 
No que diz respeito ao "conjunto de relações e fenômenos", os autores expõem o envolvimento entre o turista e uma segunda parte - que pode ser o fornecedor do serviço turístico e até mesmo a população do destino visitado.

A acepção de Hunziker e Krapf (1942) assemelha-se à apresentada por Jordi Rontaner Montejano em seu livro "Estrutura do Mercado Turístico", quando define o Turismo como "a teoria e a prática de todas as atividades relacionadas com a atração, prestação de serviços e satisfações das necessidades do turista". (MONTEJANO, 2001, p.1 1. grifo nosso).

Este conjunto de relações fundamenta o chamado Sistema de Turismo, ou SISTUR. Segundo Beni (2003, p.23) o Sistema é "o conjunto de partes que interagem de modo a atingir um determinado fim, de acordo com um plano ou princípio".

O modelo referencial produzido por Mário Beni para representar o SISTUR é compreendido por três conjuntos que se integram. O primeiro conjunto é o das relações ambientais, que envolve os fatores ecológicos, sociais, econômicos e culturais (vale destacar que se agregam a este conjunto as relações mantidas ou não com a comunidade local e seus impactos). O segundo é o da organização estrutural, formado pela infraestrutura e superestrutura. E por último, o conjunto das ações operacionais, representa a relação entre oferta e demanda, envolvendo a produção, comercialização e o consumo de serviços e produtos, formando, desta forma, o "Mercado Turístico".

As definições acerca do Turismo apresentadas até aqui, são exemplos da variedade de perspectivas analisadas neste fenômeno ao tentar defini-lo. Algumas destas acepções são mais simples, outras mais complexas e cada uma delas envolve o aspecto de principal interesse do autor que a formula.

O problema da definição do Turismo vem sendo questionado ao longo do tempo. Moesch (2004), por exemplo, pauta esta problemática desde a etimologia da palavra Turismo à proposição de uma epistemologia do estudo e conhecimento em Turismo.

A Tese de Moesch traz um levantamento de diversas definições do Turismo, desde as mais antigas como a primeira que se refere à definição do Dicionário Oxford, 
passando pelas definições etimológicas iniciadas por Fuster. Posteriormente, após várias definições e reelaborações destas que são para a autora "o resultado de um processo interpretativo teórico" (MOESH, P. 26), chega às definições que dão início ao estudo científico do Turismo e, por último, a mais recente que se relaciona à proposta de uma epistemologia do Turismo sugerida pela própria autora conforme segue:

[...] o turismo é uma prática social, ou melhor um campo de práticas histórico-sociais, que pressupõem o deslocamento dos sujeitos, em tempos e espaços, produzidos de forma objetiva, possibilitador de afastamentos simbólicos do cotidiano, coberto de subjetividades, portanto explicitadores de uma nova estética diante da busca do prazer. (MOESCH, 2004, p. 465)

Molina e Rodriguez (2001), no livro: Planejamento Integral do Turismo - um enfoque para América Latina- fazem uma crítica às definições de Turismo que possuem enfoque econômico por não considerarem os aspectos sociais, ideológicos, culturais, ambientais e psicológicos do Turismo, e, por isso, consideram que as conceituações de ordem cultural são as mais abrangentes e completas. Para exemplificar essa ideia utiliza-se como base a seguinte afirmação:

[...] o turismo atual deve ser considerado basicamente como produto da cultura, no sentido amplo deste termo. Por isso, as explicações de caráter econômico que são utilizadas para compreender a transcendência do turismo são, evidentemente, insuficientes, ainda que significativas, porque não contemplam e tampouco consideram a diversidade de dimensões do fenômeno (MOLINA; RODRIGUEZ, 2001, p.9).

A afirmação acima sugere a necessidade de novas definições que englobem as diversas dimensões do Turismo tendo como base a concepção de que este é objeto da cultura.

Considerando que a Educação Patrimonial é um instrumento de preservação e fomento à cultura, explicita-se a coerência em relacioná-la ao Turismo nestes termos.

Conforme proposto por Morin o conhecimento não deve ser algo dado de forma disjuntiva, ele deve ser integrado. Entretanto, na história ocidental houve por muito tempo a predominância do paradigma proposto por Descartes, onde se separou o campo do sujeito (filosofia) do campo do objeto (conhecimento científico), e separou-se, ainda, a "cultura dita humana" da "cultura científica". (MORIN, 2011). 
Este pensamento dicotômico foi, também, criticado pelo filósofo John Dewey, que traz como exemplo a contraposição entre "a teoria e a prática"; "a inteligência e a ação"; “o saber e o fazer". (DEWEY, 1959). Dewey atribui a estes antagonismos o motivo de determinados problemas na educação, uma vez que, por muito tempo, a experiência foi vista como "desprovida de ciência e de razão", o que resultou em uma tradição de ensino que ignora a experiência como parte do processo de aquisição de conhecimento.

Desta forma, compreende-se que a Educação Patrimonial pode ser integrada à Cultura e ao Turismo, pois, na verdade, as culturas científica e humana podem ser vistas e trabalhadas de forma que uma não anule a outra. Sendo assim, a Educação Patrimonial além de servir de instrumento para a concepção do Turista Cidadão, pode ser utilizada também como ferramenta de intermédio para a aplicação da educação em Turismo.

O problema é que, inicialmente, as questões sociais e culturais não foram o foco das discussões sobre o Turismo. Para Krippendorf (2000, p. 96):

\footnotetext{
Foi apenas muito recentemente que a opinião pública tomou enfim consciência de um problema que, na realidade, deveria ter sido estudado antes de qualquer outro: as consequências psicológicas e sociológicas do turismo $[\ldots]$.
}

O entendimento inicial de que o fenômeno turístico se tratava apenas de aspectos econômicos, ainda hoje, refletem consequências na tentativa da construção do entendimento científico do Turismo. Paiva (1995, p. 13) afirma que "o turismo insere-se dentro da lógica do 'fordismo' - designação dada pela escola de regulação francesa à generalização do consumo de massa." Esta é uma explicação cabível para a ascendência da visão econômica do Turismo.

Já para Molina e Rodriguez (2001, p. 42) essa visão parcial do Turismo se dá pela existência de "argumentos pouco sólidos e não necessariamente comprovados, o que conduziu numerosos países a experimentar erros com um custo muito alto nos âmbitos cultural, econômico e social". 
Contudo, no bojo da expansão ocorrida nos últimos anos no campo das Ciências Sociais, enxerga-se a possibilidade de o estudo do Turismo ganhar maior evidência a partir da consolidação de uma teoria própria. Há uma tendência de os estudiosos abandonarem por vez a visão determinista que relevava, sobretudo, o caráter econômico do Turismo e darem início a uma discussão voltada para a construção de uma epistemologia ou uma teoria do Turismo. Um exemplo disto é o conteúdo do artigo "A construção do objeto turístico: diálogos com a epistemologia de Gaston Bachelard e Pierre Bourdieu" produzido por Melo (2006), onde, com o intuito de contribuir para o desenvolvimento do campo epistemológico do Turismo o autor procura levantar as possibilidades do uso da metodologia proposta por Gaston Bachelard, a "construção do objeto científico" e por Pierre Bourdieu, a “construção do objeto sociológico”, e conclui que:

A construção do objeto turístico necessita que ultrapassemos o nível empírico e nos encaminhemos para uma construção racionalista, no sentido "bachelardiano", ou seja, da formulação teórica do objeto e sua relação dialética com a prática. (MELO, 2006)

Compreende-se que, ainda, há necessidade de realização de estudos, propostas e acepções a respeito do Turismo que tenham o intuito de agregar valores ao seu significado, não apenas, em relação ao sujeito que o pratica, mas que também integre o senso comum e a cultura das comunidades receptoras aos estudos científicos deste fenômeno. Contudo, acredita-se que novas reflexões a respeito do Turismo tendem a surgir mediante a visão de estudiosos que detêm questionamentos que valorizem o sentido cultural e social deste fenômeno.

Ansarah (2002, p.23) afirma que:

A educação em turismo deve estar direcionada para uma reflexão multidisciplinar e para o trabalho em equipe, contemplando contextos multiculturais em que a criatividade combine o saber tradicional ou local e o conhecimento aplicado da ciência avançada e da tecnologia.

Nestes termos, entende-se que o estudo científico deva estar aliado à prática. No que se refere à prática, estende-se também como experiência. Para Thompson (1981, p. 16):

[...] essa experiência é determinante, no sentido de que exerce pressões sobre a consciência social existente, propõe novas questões e proporciona grande parte do material sobre o qual se desenvolvem os exercícios intelectuais mais elaborados. 
Entende-se que para buscar estas novas definições cada pesquisador constrói sua perspectiva a partir da composição entre a teoria estudada e a prática social. Compreende-se, com isto, que a Educação Patrimonial possa ser envolvida nas novas discussões estabelecidas, uma vez que, por meio dela, é real a possibilidade de se realizar a práxis.

É a partir deste contexto que se busca promover uma pesquisa que integre o estudo sociocultural e fenomenológico do Turismo às práticas e experiências vivenciadas pelos docentes participantes do projeto $\operatorname{Re}(v i)$ vendo Êxodos, para que desta forma possa-se compreender em que medida se dá a formação do Turista Cidadão.

\section{2 - Experiência e Educação}

O autor Edward Palmer Thompson trabalha o conceito de experiência propondo que é a partir da experiência histórica dos indivíduos que ocorrem as mudanças sociais e culturais.

Thompson, em seu livro, "A miséria da teoria ou um planetário de erros" precisamente no capítulo "O termo ausente: Experiência"-, critica o pensamento do filósofo Louis Althusser por compreender que este trata o conhecimento como fruto exclusivo do pensamento, ignorando a existência real dos fatos históricos e desconsiderando a relação entre sujeito e objeto do conhecimento. Neste sentido, Thompson afirma que:

\footnotetext{
"A experiência, portanto, não chega obedientemente, da maneira proposta por Althusser. Suspeita-se aqui a presença de uma noção muito definhada de conhecimento. Ofereceu-nos ele menos uma epistemologia que leva em conta os movimentos formativos reais da consciência do que uma descrição de certos procedimentos da vida acadêmica." (THOMPSON, 1981, p.16).
}

Manifestando as influências do Materialismo Histórico de Karl Marx, mas longe de se prostrar servil às suas obras, Thompson em uma reanálise aos pensamentos Marxistas considera que a construção do conhecimento se dá pela relação dialética entre sujeito e objeto e explica, através desta relação, a origem da experiência: 
"[...] primeiro, o diálogo entre o ser social e a consciência social, que dá origem à experiência; segundo, o diálogo entre a organização teórica (em toda a sua complexidade) da evidência, de um lado, e o caráter determinado de seu objeto, de outro" (Thompson, 1981, p. 42).

Desta forma, Thompson mostra que a teoria deve sempre permanecer em diálogo com a realidade prática histórico-social do sujeito.

Thompson, ainda em crítica aos pensamentos de Althusser e seus seguidores, que levam apenas em consideração as questões teóricas, explica que:

\footnotetext{
"Os homens e mulheres também retornam como sujeitos, dentro desse termo - não como sujeitos autônomos, "indivíduos livres", mas como pessoas que experimentam suas situações e relações produtivas determinadas como necessidades e interesses e como antagonismos, e em seguida "tratam" essa experiência em sua consciência e sua cultura (as duas outras expressões excluídas pela prática teórica) das mais complexas maneiras (sim, 'relativamente autônomas') e em seguida (muitas vezes, mas nem sempre, através das estruturas de classe resultantes) agem, por sua vez, sobre sua situação determinada.". (Thompson, 1981, p. 182).
}

Embora em "O termo ausente: Experiência" a crítica de Thompson se aprofunde em questões ainda mais complexas do que a exclusão das expressões cultura, consciência e experiência pela prática teórica, como a tentativa de Marx quanto à “necessidade de proporcionar uma certa 'genética' à sua teoria” (THOMPSON, 1981, p. 182), o que se tenta buscar nesta explanação, envolve precisamente a crítica quanto à ausência do termo experiência na teoria de outros autores e a defesa desta categoria por Thompson.

Para Thompson o ponto extremo do reducionismo recai sobre a prática teórica, uma vez que esta constitui a redução das disciplinas do conhecimento em apenas um tipo "básico" e único de teoria, uma teoria ulterior. Se opondo a esta prática teórica, Thompson considera que a mente, ao recusar a investigação empírica se depara com o sistema de fechamento, se confina em seus próprios limites, contudo "se voltarmos à 'experiência' podemos passar desse ponto, novamente para uma exploração aberta do mundo e de nós mesmos.” (THOMPSON, 1981, p. 185).

Compreende-se com a obra de Thompson que através da análise da experiência histórica torna-se possível encontrar novos conhecimentos e o desenvolvimento de 
métodos próprios a cada investigador rumo ao entendimento comum de todo o processo histórico, além da possibilidade de perceber as controvérsias e deturpações da teoria pré-estabelecida.

Este processo se torna possível, uma vez que, a "experiência" leva o investigador à:

\footnotetext{
"reexaminar todos esses sistemas densos, complexos e elaborados pelos quais a vida familiar e social é estruturada e a consciência social encontra realização e expressão." (THOMPSON, 1981, p. 188).
}

São alguns exemplos, desses sistemas densos, citados por Thompson: "formas simbólicas de dominação e de resistência", "parentesco", "costumes", "as regras visíveis e invisíveis da regulação social", ou seja:

“[...] tudo o que, em sua totalidade, compreende a "genética" de todo processo histórico, sistemas que se reúnem todos, num certo ponto, na experiência humana comum, que exerce ela própria (como experiências de classe peculiares) sua pressão sobre o conjunto." (THOMPSON, 1981, p. 189)

Faz-se necessário incluir, também, o papel da educação dentro deste processo histórico mencionado por Thompson, uma vez que, a educação é uma das questões que exercem grande influência na experiência humana.

Para o autor John Dewey a educação é para a vida social, tão importante quanto, a nutrição e a reprodução são para a vida fisiológica, (DEWEY, 1967, p. 7) e, ainda neste sentido, enxerga a experiência como sendo inerente à vida.

Dewey nomeia de "experiência educativa" (DEWEY, 1967, p. 16) o processo de experiência reflexiva onde o ser humano se atenta ao processo de aquisição de novos conhecimentos ou conhecimentos mais extensos como resultado natural da experiência.

Desta forma, o local da educação formal deve ser um ambiente favorável às experiências construtivas e educativas.

Dewey enxerga na educação uma forma de reconstrução e reorganização da experiência, uma vez que é através da educação que o indivíduo se torna capaz de 
perceber o sentido de cada experiência vivida se permitindo direcionar melhor as experiências futuras.

O autor relaciona, de forma muito específica, a educação à filosofia. Para ele a filosofia representa a teoria geral da educação. Ao explicar esta relação proposta por Dewey entre a filosofia e a educação, M. Nazaré de C. Pacheco Amaral traz a seguinte informação:

“... a sua \{da filosofia\} preocupação maior deverá ser a de orientar a educação no sentido de poder proporcionar ao ser humano, ainda imaturo, a incorporação dos padrões próprios ao homem maduro, qual seja, o homem formado à luz dos princípios democráticos, os únicos válidos para esse mundo, produto de sua própria criação.” (AMARAL, 1990, p. 29) (Grifo nosso).

Este homem imaturo do qual a autora trata, não se refere apenas à imaturidade quanto à idade do sujeito, mas à inconsciência dos princípios democráticos. Nesta perspectiva entende-se que a educação tem fundamental importância para tornar o homem um ser provido de conscientização quanto ao seu papel em uma sociedade democrática.

Ainda nesta perspectiva, para Dewey a contínua reorganização da experiência só é possível dentro de uma sociedade verdadeiramente democrática que dê mais liberdade aos seus membros.

Ao enxergar a experiência como parte do processo de aquisição de conhecimento, esta é incluída como peça fundamental na compreensão e ressignificação de práticas e conceitos pertencentes a uma sociedade.

\section{Segundo Dewey,}

"O melhor da experiência é, por esta forma, representado pelos vários trabalhos manuais - pelas artes da paz e da guerra. O sapateiro, o tocador de flauta, o soldado, sofreram da experiência para adquirirem suas habilidades." (DEWEY, 1959, P. 290). 
Em relação às habilidades citadas por Dewey, estas são a própria expressão do saber dos indivíduos que compõem uma sociedade, ou seja, é a experiência por eles vivida que dá início ao surgimento de todo e qualquer patrimônio material e imaterial.

A experiência dá vida aos saberes, crenças, conhecimentos, costumes e práticas dos grupos sociais, e estes, por sua vez, são explicados às gerações mais novas por meio do processo educativo. Assim, considera-se que "é pela educação que a sociedade se perpetua". (DEWEY, 1967, P.21).

\section{3 - A Educação Patrimonial e a Formação da Identidade do Turista}

\section{Cidadão}

O Turista Cidadão é uma abordagem recente apresentada pelas escritoras Susana Gastal e Marutschka Martini Moesch. Para melhor entendimento, antes de se explanar este conceito (Turista Cidadão) é fundamental que se compreenda o conceito de cidadania, para tanto, é interessante abordar algumas referências teóricas que poderão auxiliar nessa compreensão.

Em seu livro, "O que é Cidadania”, Maria de Lourdes Manzini Covre faz um exercício de aproximação do termo Cidadania começando por esclarecer o que é ser cidadão quando diz que: "Ser cidadão significa ter direitos e deveres, ser súdito e ser soberano". (MANZINE-COVRE, 2001, p. 9).

A cidadania pressupõe o pleno exercício de direitos civis, políticos, sociais e culturais, assim como sua livre expressão.

Para Jose Bernardo Toro "um cidadão é uma pessoa capaz de, em cooperação com outras, criar ou transformar a ordem social na qual ela mesma quer viver e a qual se compromete cumprir e proteger, para a dignidade de todos". (Toro, 2005, p.20). O autor ressalta, ainda, a compreensão quanto à ordem social que incluem as leis, os costumes, as instituições, as tradições etc. E que, de fato, deve haver a percepção pelos próprios cidadãos quanto à necessidade de mudança ou substituição por uma nova ordem social no momento em que a atual não esteja produzindo dignidade. 
Ao analisar a cidadania pela concepção de Paulo Maksenas que a apresenta como um conceito-rede (conceito que articula outros conceitos), Gastal e Moesch propõem a seguinte definição para cidadania:

[...] processo histórico de conquista popular, através do qual a sociedade adquire, progressivamente, condições de tornar-se sujeito histórico consciente e organizado, com capacidade de conceber e efetivar processo próprio. O contrário significa a condição de massa de manobra, de periferia, de marginalização. (GASTAL; MOESCH, 2007, p. 33);

Como se observa na leitura da obra "Cidadania no Brasil - O longo caminho" de José Murilo de Carvalho, apesar de se tratar de um país dito democrático, existe uma lentidão e incompletude em relação ao progresso das questões de cidadania no Brasil. O que se nota é que existe grande dificuldade para colocar em prática o que foi imposto por lei.

Apesar da constitucionalização dos direitos civis o país enfrenta, ainda hoje, as consequências da herança colonial que, entre muitas outras restrições, encara as dificuldades de um Estado envolvido, em muito, com o setor privado, o que reduz o comprometimento com o público.

O que se tem no Brasil é uma democracia fadada à representação popular, onde se elegem representantes dos cidadãos que devem tomar a melhor decisão por eles. Estes cidadãos, quando desprovidos da conscientização do que é melhor para eles, se tornam alheios e indiferentes aos processos decisórios.

Entende-se, assim, que a cidadania deve ser constituída historicamente através da participação popular na construção gradativa de novos valores sociais, algo diferente disso, pode levar à manipulação do indivíduo colocando-o à margem das questões sociais.

Uma das principais perspectivas neste contexto é que a Cidadania só existe quando o cidadão toma consciência dos seus direitos e deveres, pois não basta tê-los, deve-se exercê-los em plenitude. Assim, enxerga-se a Educação Patrimonial como um 
meio de conscientizar o sujeito quanto aos seus direitos e deveres relacionados à cultura material e imaterial, quanto à qualidade de vida e à própria cidade onde vive.

Através da Educação Patrimonial o cidadão poderá aprender a enxergar a sua cidade de maneira diferenciada, levando à construção e prática de um novo olhar e, consequentemente, ao surgimento do Turista Cidadão:

\footnotetext{
Olhar a cidade com maior cuidado não é mais uma tarefa exclusiva dos turistas que a percorrem. Mesmo para os moradores das cidades, a sua complexidade coloca, cada vez mais, maiores desafios. Decifrá-los é fundamental para sobreviver e viver nas cidades com qualidade. (GASTAL; MOESCH, 2007, p.19)
}

Fazer com que a comunidade local incorpore ao seu cotidiano novos hábitos de visitação em sua própria cidade é propor o surgimento de um novo perfil de cidadão que passa a compreendê-la com o olhar de turista.

Por fim:

[...] trata-se, assim, do conceito de turista cidadão, o habitante que desenvolve um relacionamento diferenciado com o local onde mora no seu tempo de lazer, quebrando o modelo existencial da sociedade industrial criticado por Jost Krippendorf (trabalho - moradia - lazer - viagem), de acordo com o qual o lazer, as práticas sociais capazes de restabelecer o equilíbrio físico e emocional do homem contemporâneo, só seria possível em lugares distantes da própria residência (SALES, 2006).

Sendo assim, o Turista Cidadão apropria-se com maior competência dos espaços e situações de sua própria cidade, num novo exercício de cidadania. (GASTAL; MOESCH, 2007, p.60) E é ainda, capaz de perceber tudo o que envolve a cidade mesmo ao caminhar em direção ao seu trabalho, ao mercado ou à escola, por exemplo. Para ele, não existe um momento específico para se apreciar a paisagem que o rodeia e utilizar-se dela.

Intimamente ligada à formação da identidade cultural de um povo, bem como sua diversidade e simbologia, a cidadania deve ser levada em consideração ao tratar-se de processos relacionados ao Turismo, no que tange à implementação de políticas 
públicas neste seguimento. Desta forma, os investimentos da infraestrutura dos atrativos turísticos devem ser pensados e aplicados em condições equiparáveis ao investido na infraestrutura básica, no que contempla a proporcionalidade da população da região que também usufrui, ou possa vir a usufruir, destes espaços, prevendo que a falta de planejamento adequado pode acarretar à subutilização destes ambientes.

O que se tem, até então, quanto à definição de Turista Cidadão está, intimamente, ligado ás questões locais, contudo, mais do que isto, o Turista Cidadão é, também, capaz de agir com cidadania e respeito aos espaços públicos e privados localizando-se eles em sua cidade ou não. Para a prática do Turismo cidadão não existem limites ou fronteiras. Ser Turista Cidadão é ser capaz de compreender e usufruir da oportunidade oculta da experiência turística sem deixar de cumprir o seu papel como cidadão.

Tendo esta pesquisa o intuito de mostrar como se dá o processo de formação do Turista Cidadão a partir da experiência vivida pelo indivíduo em projeto específico de Educação Patrimonial, propõe-se a seguinte hipótese de pesquisa: $O$ sujeito que vivencia práticas incentivadas e propostas pela educação patrimonial é capaz tanto de apreender dinamicamente, como praticar o Turismo de forma cidadã.

A Educação Patrimonial como atividade educativa torna-se mais do que uma instrução à prática responsável e consciente de preservação do Patrimônio, servindo para responder determinadas questões que vão além da simples dinâmica do comportamento culturalmente correto.

Ao pensar o conceito de Educação Patrimonial, é preciso elucidar algumas considerações quanto ao Patrimônio Cultural.

Patrimônio Cultural são todos os bens imateriais e materiais que derivam dos saberes e fazeres de um povo.

Funari e Pinsky afirmam que por muitas vezes se tratar o termo Patrimônio de uma forma solene, acaba-se entendendo que dele façam parte apenas as grandes obras 
de arte, contudo o Patrimônio Cultural envolve todas as coisas constituídas por parte do engenho humano. (FUNARI; PINSKY, 2009, p. 9).

Ao abordar o Patrimônio Cultural para o Turismo os autores trazem a seguinte questão:

O turismo tende a considerar o patrimônio cultural como aquele que se volta para certos tipos de atividades mais propriamente 'culturais', tais como as visitas a museus, a cidades históricas ou a roteiros temáticos, como a rota dos queijos e a dos vinhos, por exemplo.

A definição dos autores pode trazer certa confusão entre os conceitos de Patrimônio Cultural e Turismo Cultural. Vale destacar que as atividades culturais relatadas que envolvem visitas aos locais descritos se referem ao Turismo Cultural; já o Patrimônio Cultural delimita as manifestações, monumentos, o saber-fazer de um grupo e caracterização da comunidade, propriamente ditos.

É importante destacar a relevância do Patrimônio Cultural como contribuição à história e à memória dos grupos sociais conforme constata-se ao analisar o texto da Constituição Brasileira de 1988:

Constituem patrimônio cultural brasileiro os bens de natureza material e imaterial, tomados individualmente ou em conjunto, portadores de referência à identidade, à ação, à memória dos diferentes grupos formadores da sociedade brasileira, nos quais se incluem:

I - as formas de expressão;

II - os modos de criar, fazer e viver;

III - as criações científicas, artísticas e tecnológicas;

IV - as obras, objetos, documentos, edificações e demais espaços destinados às manifestações artístico-culturais;

V - os conjuntos urbanos e sítios de valor histórico, paisagístico, artístico, arqueológico, paleontológico, ecológico e científico

É importante ressaltar a existência de decretos posteriores a esta lei, e que proporcionaram mecanismos de oficialização de registro deste Patrimônio imaterial. 
Ao analisar a relação da educação patrimonial com o Turismo identifica-se, ainda, a possibilidade de reeducação do atual perfil dos membros da uma determinada sociedade. Este se tornaria um habitante da cidade carregado de entendimento sobre a cultura local e importância da valorização dos bens materiais e imateriais. $\mathrm{O}$ cidadão dotado de conhecimento sobre sua comunidade e que a valoriza por olhar de forma mais aprofundada para tudo que a envolve, se torna capaz de transmitir os valores que sua cultura possui àqueles que visitam a sua cidade.

Vale ressaltar, que não existe nenhum modelo padronizado e pré-estabelecido para se desenvolver a Educação Patrimonial, pois esta pode ser feita de diferentes formas, em diferentes lugares e para grupos de pessoas de diferentes faixas etárias, gêneros e condições socioeconômicas. Entretanto, independente da forma como seja aplicada, considera-se a Educação Patrimonial uma importante oportunidade para a otimização benéfica e responsável da prática turística pelos sujeitos que vivenciam este fenômeno e, ainda, um elemento de auxílio ao entendimento científico do Turismo.

A Educação Patrimonial possibilita a conscientização do educando quanto à importância da valorização de sua cultura incentivando-o à prática responsável de preservação do Patrimônio.

Considerando-se também que a educação patrimonial auxilia na compreensão da sociedade e do momento histórico no qual o cidadão está inserido compreende-se a importância de projetos que promovam uma conscientização cultural do indivíduo que exercita a cidadania consciente do seu papel na sociedade. Contudo:

\footnotetext{
"Enquanto o foco patrimonial estiver voltado para "violas caipiras", "panelas de barro", "rituais", "festas" e "igrejas", a dinâmica de uso desses objetos e práticas está fadada ao desaparecimento ou, pior, ao artificialismo da continuidade da prática justificada em si mesma, do preservar porque é considerado "cultural", tutelado pelo Estado e por críticos, porque é importante e porque deve ser preservado" (IPHAN/PB, João Pessoa, 2011).
}

Sendo assim, é imprescindível compreender a importância das comunidades como referências culturais responsáveis pelo surgimento de sua cultura, e não sobrepor o valor dos bens simbólicos materiais e imateriais derivados sobre estas comunidades. 
Deve-se considerar, também, a necessidade de esclarecer estas informações aos membros das comunidades para que possam compreender a importância da preservação de sua cultura, principalmente quando submetidos à atividade turística e passíveis de sofrer um processo de adaptação em suas formas de viver, fazer e, até mesmo, servir.

Esta adaptação ${ }^{2}$ pode ocorrer apenas pelo intuito de se assemelhar aos modos de vida do turista que visita esta comunidade, ou ainda, aos modos de vida veiculados pelos meios de comunicação como os mais adequados ou como sendo os mais utilizados pela maioria.

Um exemplo deste tipo de adaptação dos costumes, de fácil percepção, são as mudanças nas comunidades rurais receptoras de Turismo. Em muitos casos, nota-se o tipo de alimentação natural sendo substituído pelos alimentos industrializados, e em alguns casos é possível notar mudanças na própria forma de servir os alimentos substituem-se os utensílios feitos de barro pelos de inox, por exemplo.

Nestes casos específicos, pode-se entender que as mudanças são apenas prejudiciais para a cultura receptora, no entanto, há que se levar em consideração o fato de que estas mudanças possam também ocorrer por motivo de conforto da própria comunidade.

É importante compreender que com o passar das experiências e situações vividas em conjunto pelos grupos sociais, os conceitos e as práticas adquirem novos significados devido às necessidades que surgem naturalmente ou que são impulsionadas pelos novos desejos de evolução consequentes da história coletiva.

Considerando a Educação Patrimonial uma instrução à prática responsável e consciente de preservação do Patrimônio e, também, objeto de auxílio na construção da cidadania ao complementar a constituição dos valores morais e percepções de simbolismo pelo educando, podendo, ainda, incentivar às práticas de um Turismo Responsável ao promover a formação de indivíduos que valorizem a identidade das

\footnotetext{
${ }^{2}$ Evita-se, neste estudo, utilizar o termo "aculturação" por compreender que este está vinculado a um sentido pejorativo o que poderia prejudicar a tentativa de esclarecer que um processo de mudança dos hábitos culturais, nem sempre, é prejudicial para a comunidade que passa por um processo de ressignificação.
} 
comunidades, percebe-se que esta pode ser compreendida a partir das perspectivas sociais do Turismo.

A promoção da Educação Patrimonial nas comunidades receptoras aumenta o interesse dos cidadãos em se tornarem membros ativos da sociedade em que se relacionam, capazes de criar sua própria identidade a partir da convivência e troca de experiências com os demais integrantes de seu grupo social e, sobretudo, cidadãos conscientes da importância de proteger seu patrimônio e cultura para que possam ser preservados e deixados como herança às futuras gerações.

Nestes termos, faz-se necessário ressaltar a importância de uma sociedade democrática que possibilite o direito de construção da identidade de cada indivíduo, uma vez que, a identidade não se trata de um papel que deva ser representado pelo indivíduo, mas sim algo construído por ele em conjunto por meio das relações mantidas com os demais cidadãos.

\section{4 - Identidade e Globalização}

Há que se levar em consideração que a liberdade da democracia não é autossuficiente na construção da identidade. A responsabilidade maior por esta construção recai aos próprios indivíduos que, de acordo com a crítica levantada pelo autor Zygmumt Bauman, em muitas de suas obras, se entregam à liquidez das relações em meio às muitas opções trazidas pela modernidade e globalização.

Segundo Bauman, para os habitantes do "líquido mundo moderno", "uma identidade coesa, firmemente fixada e solidamente construída seria um fardo, uma repressão, uma limitação da liberdade de escolha”. (BAUMAN, 2005, P. 60).

Estes habitantes do mundo líquido deixam de fazer parte de grupos sociais sólidos e reais e passam a buscar ou estabelecer comunidades virtuais onde podem facilmente entrar e com a mesma facilidade deixar de fazer parte. Esta liberdade de fazer e desfazer laços líquidos desobriga e despreocupa estes indivíduos de 
solidificarem as relações pessoais e, principalmente, deixam sempre disponíveis a possibilidade de desfrutar da "onda de oportunidades mutáveis e de curta duração".

Em seu livro, "Amor Líquido" Bauman relaciona a compulsão pela busca de novos e curtos relacionamentos dos habitantes do mundo líquido com o consumismo exacerbado e ressalta:

\footnotetext{
"quando a qualidade o decepciona, você procura a salvação na quantidade. Quando a duração não está disponível, é a rapidez da mudança que pode redimi-lo." (BAUMAN, 2004, P. 77).
}

Contudo, para Bauman, as comunidades virtuais criam apenas uma "ilusão de intimidade" e um "simulacro de comunidade", elas não podem substituir fielmente a realidade e tampouco podem substanciar a identidade pessoal, o que essas comunidades virtuais fazem é dificultar que a pessoa chegue a um acordo com o próprio eu.

Apesar de sempre se mostrar contrário às tentativas de atribuir um culpado específico aos problemas de identidade enfrentados pela sociedade moderna, Bauman relaciona a globalização como um fator de grande influência. Para o autor "globalização significa que o Estado não tem mais o poder ou interesse de manter uma união sólida e inabalável com a nação". (BAUMAN, 2005, P.34).

A partir da globalização o Estado passa a estabelecer relações e parcerias com o mercado global tendo, assim, muito menos necessidade dos suprimentos locais. Bauman recorda a tríade de direitos de Thomas Marshall e explica que com o fortalecimento das relações globais do Estado, este perde os direitos econômicos, oferece direitos políticos estritamente limitados e os direitos sociais perdem lugar para o dever individual de cuidar de si e adquirir vantagem sobre os demais.

Para Bauman, este é o motivo de no casamento entre Estado e nação seus membros se tornarem indiferentes quanto à união, uma vez que as pessoas que buscam por uma identidade sentem-se inseguras em relação aos poderes do Estado descartando a possibilidade de construir uma identidade patriótica. Assim como, esta relação é influenciada e liquefeita pela globalização, o mesmo ocorre com as relações nos grupos sociais. 
Os avanços tecnológicos que trazem diversas propostas de produtos e serviços que prometem solucionar os problemas sociais são, também, fatores que influenciam nesta liquidez da sociedade e, é neste sentido, que Bauman critica o mau uso das avançadas pesquisas e tecnologias, que permite o consumo do absurdo, como a escolha, durante a gestação, da composição genética do filho que irá nascer. Citando Ulrich Beck, o autor explica esse fato como uma estratégia escolhida para solucionar biograficamente os problemas produzidos socialmente. (BAUMAN, 2004, P. 62).

Após análise dos problemas de identidade, sugeridos por Bauman, enfrentados atualmente pela sociedade surge uma inquietação: seriam estes - uso inadequado dos avanços tecnológicos e globalização, os grandes obstáculos em meio ao processo educativo?

Essa inquietação origina-se da compreensão de que o meio influencia completamente o processo educativo, uma vez que "a atividade educativa não se processa no vácuo, independente de objeto ou condições" (DEWEY, 1967, P.21), mas pelo contrário:

“[...] ela é sempre uma resposta a estímulos específicos ou gerais, nascidos do próprio organismo e do meio ambiente em que o indivíduo vive." (DEWEY, 1967, P.21).

Compreender que os indivíduos do mundo líquido sintam-se confortáveis com a liquidez de suas relações é, no máximo, aceitável, contudo, pensar que estas relações líquidas possam interferir negativamente no processo educativo de próximas gerações é, no mínimo, inquietante.

Dewey considera a vida social como um conjunto de crenças, costumes, instituições, ideias e linguagem que são apreendidos lenta e laboriosamente e ensinados dos mais velhos para os mais novos solicitamente e que, sem esse ensinamento de valores entre a geração adulta e a geração infantil, "os grupos sociais depressa retornariam às mais absolutas condições de primitivismo". (DEWEY, 1967, P. 19). 
Seria este o problema? Estaria esta sociedade moderna e líquida retornando às condições primitivas em relação à vida social? Estas relações líquidas afetarão no processo educativo da geração infantil?

Apesar da inquietação quanto aos questionamentos levantados, ainda assim, é preferível considerar que os processos educativos tenham influência e solidez suficiente para ensinar os indivíduos a direcionarem suas experiências futuras.

As obras de Bauman despertam a atenção para as mudanças sociais e para a banalização nas relações que ocorrem mediante as práticas cotidianas, contudo, remetem que o sentido da globalização se restringe à perversidade, a negatividade.

O autor Nestor Garcia Canclini, em seu livro "Culturas Híbridas", traz uma perspectiva diferente e otimista ao relacionar a cultura à modernidade. Canclini evita utilizar termos como alta e baixa cultura e traz o conceito de culturas híbridas.

O autor chama de hibridação:

\footnotetext{
"processos socioculturais nos quais estruturas ou práticas discretas, que existiam de forma separada, se combinam para gerar novas estruturas, objetos e práticas." (CANCLINI, 1997, p.19).
}

Neste sentido, a globalização tem um papel de facilitador e multiplicador das culturas híbridas, uma vez que, com a ascensão da internet, conhecer as culturas e inovações de diferentes países se tornou algo de fácil acesso o que torna possível essa combinação de práticas.

Também o autor Raymond Williams, em seu livro "Política do modernismo" no capítulo intitulado "Cultura e Tecnologia" aborda uma interessante discussão sobre as inovações tecnológicas que são de significativa importância para esta pesquisa e que auxiliam na análise do processo de ressignificação cultural.

\footnotetext{
${ }^{3}$ Vale destacar que o referido livro traz vários exemplos próximos da realidade espacial e temporal do autor: Reino Unido final do século XIX e decorrer do século XX.
} 
Williams inicia o capítulo com uma crítica ao pensamento contemporâneo no que diz respeito à relação entre cultura e tecnologia devido a este restringir sua relação ao entendimento de que a alta tecnologia equivale à distribuição da baixa cultura e que a alta cultura tem a garantia de se manter com baixo nível tecnológico. Entende-se, neste sentido, que a baixa cultura remete à cultura de massa, amplamente divulgada pelas mídias; e que a alta cultura faz menção à cultura restrita, pouco divulgada, cultura das minorias favorecidas. É este o pensamento criticado por Williams.

Para o autor este ponto de vista trata a alta cultura como sendo superior a baixa cultura e este argumento é pautado por "uma combinação profana de determinismo tecnológico e pessimismo cultural." (WILLIAMS, 2011, p.128).

O determinismo tecnológico citado por Williams defende que o surgimento de uma nova tecnologia é o fator responsável pelas mudanças na sociedade ou setor no qual esta tecnologia está inserida. A crítica de Williams a esta teoria se dá uma vez que para ele, não é a tecnologia que promove mudanças na sociedade, mas sim a própria sociedade que apresenta determinações de cunho econômico e político que levam ao avanço da tecnologia.

O autor afirma, ainda, que "praticamente toda pesquisa técnica e experimento são realizados dentro de relações sociais e formas culturais já existentes, tipicamente para objetivos que já são, em geral, previstos" e que, além disso, apenas quando a invenção técnica é selecionada para um investimento visando à produção, e quando ela é desenvolvida conscientemente para usos sociais específicos (necessidades sociais que podem ser supridas) é que ela ganha relevância. Como exemplo, o autor cita a descoberta científica das ondas de rádio por Hertz e o caso da transmissão via satélite. Atualmente pode-se trazer a título de exemplo a própria invenção do computador.

Williams salienta que com o avanço tecnológico surge o interesse das corporações em uma nova fase de consumismo "pós-industrial" e que, com isto, muitos radicais tomaram posições defensivas ao identificarem as tecnologias com as corporações que as controlavam e com a fase do capitalismo exacerbado que dominava a época ("hipercapitalismo paranacional"). 
Nesta dimensão o autor apresenta duas direções diferentes da distribuição da cultura por parte das corporações tecnológicas, de um lado o sistema de serviço público e de outro o sistema comercial. Para o autor, o importante não é comparar puramente as distinções dentre estes dois sistemas, mas sim fazer tal comparação lembrando "das formas em mutação de seu entrelaçamento com a sociedade capitalista em desenvolvimento". (WILLIAMS, 2011, p.134).

Nesta perspectiva, Williams esclarece que o sistema de serviço público passou por um período protecionista de regulamentação estatal contra o mercado competitivo, mas que posteriormente o próprio Estado passa a fazer parte do sistema capitalista direta ou indiretamente e as instituições privilegiadas enfraquecem, mas não deixam de existir. (cita como exemplo a emissora BBC) dando lugar à combinação de Estado e Capitalismo e ao surgimento de novas instituições privilegiadas o que o autor chama de patrocinadores ou novos padrinhos.

Juntamente com a sensação de uma nova tecnologia como inevitável ou irrefreável derivada de um marketing de fortes interesses, surge um modo de "pessimismo cultural", (WILLIAMS, 2011, p. 128).

Para Willians o pessimismo cultural deriva das tentativas frustradas das instituições privilegiadas da cultura de minoria de lutar contra "as pressões poderosas de uma cultura patrocinada pelo capitalismo" e, principalmente, devido à convicção de que não há, além do passado, nada a ser ganho, por haver, por outras razões, uma recusa deliberada de qualquer ordem social ou cultural genuinamente alternativa.

Entende-se com base nas reflexões do autor, que o pessimismo cultural faz, de certa forma, terrorismo às novas tecnologias e a globalização e suas possibilidades de difusão cultural. Uma vez que sua raiz “está na convicção de que não há, além do passado, nada a ser ganho". (WILLIAMS, 2011, p.135).

\footnotetext{
${ }^{4}$ Entende-se como pessimismo cultural o pensamento de que uma nova tecnologia só pode influenciar a sociedade e sua cultura de maneira negativa e/ou prejudicial.
} 
Uma breve ponderação apresentada por Funari e Pinsky pode ser relacionada à crítica de Williams e aqui se faz necessária: "a ideia que queremos apresentar aqui é a de que não é o que se vê, mas o como se vê, que caracteriza o turismo cultural." (FUNARI; PINSKY, 2009, p. 8).

Os autores trazem dois exemplos de bens culturais que expressam essa diferenciação entre o que se vê como um bem cultural para como se vê um bem cultural, o que não desvaloriza um bem em detrimento do outro: $O$ primeiro refere-se ao sanduíche do $\mathrm{MC}$ ' Donalds como bem cultural global, já o segundo refere-se a um mesmo peixe que pode ser preparado de diferentes maneiras em diferentes locais como bem cultural local. (FUNARI; PINSKY, 2009, p. 8).

Os exemplos apresentados pelos autores, assim como a crítica de Williams mostram que os bens produzidos pela globalização fazem parte da cultura, assim como os bens locais, uma vez que é a própria necessidade humana que impulsiona o surgimento destes bens globais.

A globalização, apesar de suas restrições, auxilia na percepção das mudanças dos aspectos socioculturais e até mesmo comercias de determinadas sociedades, contudo o que Williams traz em consideração, é que estas mudanças não ocorreram devido à intervenção das novas tecnologias de informação, mas que, de fato, são as transformações nas estruturas destas sociedades que tornam necessário o surgimento de tecnologias que supram suas novas necessidades.

A autora Maria Cecília Londres Fonseca, em seu texto, "Para além da pedra e cal: por uma concepção ampla de patrimônio cultural", também aborda apontamentos que representam os benefícios da globalização para o Patrimônio Cultural. A autora ressalta que com os intensos fluxos migratórios, os processos de comunicação muito ágeis, a presença e a interpenetração de tradições culturais distintas que são consequências nítidas do processo de globalização, acarretou no que tem sido chamado de "desterritorialização da cultura". (FONSECA, 2009, P.73).

Estes processos da globalização deram consequência à ampliação da noção de patrimônio cultural, o que possibilita o reconhecimento desses aspectos culturais, por meio de tombamento, como patrimônios mundiais, o que contribui para inserção de um 
país ou um grupo social na comunidade internacional, levando a aquisição de benefícios políticos e econômicos.

Desta forma, enxerga-se que a Educação Patrimonial não deve trabalhar apenas no fomento à valorização da cultura de uma determinada comunidade para demonstrar a importância de seu momento atual, ou ainda a importância da compreensão dos novos significados apropriados às práticas e símbolos. É imprescindível que se busque a compreensão dos aspectos que levaram a construção da mesma, transformando esta reflexão em um exercício de conscientização quanto aos motivos que levaram à necessidade de ressignificação ou manutenção da cultura. Deste modo, se torna possível o entendimento quanto ao valor agregado àquele bem material tombado, àquele saber fazer preservado ou, ainda, quanto aos significados dos ditos populares relacionados ao local de residência daquela comunidade. Além disso, torna-se capaz o entendimento de determinadas mudanças, semelhanças e diferenças nas formas de viver dos diversos grupos sociais.

É neste sentido que será feita a análise do Projeto Re(vi)vendo Êxodos, como um processo educativo capaz de orientar os estudantes por meio da Educação Patrimonial e provendo um ambiente de interação social.

Analisando a educação Patrimonial com base no pensamento complexo de Morin, de forma que as partes integrem o todo, onde não é o todo que justifica as partes ou as partes que justifique o todo, mas que de forma integrada os dois se complementem, compreende-se que Educação Patrimonial está nas manifestações populares e através dos diversos meios de alcançá-la, assim como estas manifestações e os meios estão na Educação Patrimonial. Ainda neste pensamento, integram-se os sujeitos que se educam neste processo.

Assim a prática problematizadora, ocorre quando mutuamente, educador e educando desenvolvem a possibilidade de captar e compreender o mundo que lhes aparece, a partir de suas relações com este mundo. Dessa maneira a realidade deixa de ser estática e torna-se uma realidade em transformação, em processo. 


\section{CAPÍTULO 2:}

\section{O PROJETO RE(VI)VENDO ÊXODOS ${ }^{5}$}

\subsection{Referências Históricas}

O projeto nasceu de uma mudança na grade curricular. No ano 2000 foram reduzidas as cargas horárias de algumas disciplinas e incluída a disciplina de PD (Prática Diversificada) para matemática e português. O intuito era que os professores das disciplinas tradicionais colocassem em prática novas ideias e projetos que estimulassem o conhecimento dos alunos.

No ano de 2001, como continuidade das mudanças curriculares, os professores responsáveis pelas disciplinas da área de humanas (história, geografia, filosofia e sociologia) foram impulsionados a realizar, em conjunto, uma atividade pedagógica que tivesse o mesmo intuito que a disciplina de Prática Diversificada- (PD), porém, como atividade extracurricular.

O professor Luís Guilherme Baptista ${ }^{6}$ sugeriu aos demais professores que levassem os alunos do $2^{\circ}$ e $3^{\circ}$ anos do Ensino Médio para visitar a exposição Êxodos de Sebastião Salgado que estava em Brasília no espaço ECO, localizado, naquela época, no Edifício Venâncio 2000.

\footnotetext{
${ }^{5}$ Os dados e informações específicos sobre o Projeto Re(vi)vendo Êxodos foram disponibilizados pelo Professor Luís Guilherme por meio de documentos e por entrevista gravada por aparelho eletrônico em 04 de junho de 2014 às 15:41.

${ }^{6}$ Luís Guilherme Moreira Baptista é "co-criador" do Projeto Re(vi)vendo Êxodos e Criador da Caminhada, dentro do Projeto. Bacharel e Licenciado em História pelo Centro de Estudos Unificados de Brasília - CEUB, possui especialização em Artes Cênicas, é ator e diretor com registro profissional, participou de produções em teatro, cinema, vídeos, publicidade, filmes e novelas. Produtor cultural desde os anos 80, durante o governo de Cristovam Buarque (1995-1998) escreveu, coordenou e fez parte da equipe da Secretaria de Cultura em projetos como Temporadas Populares, Classe Arte, Prêmio Aluízio Batata, Meia sola e outros. Atualmente permanece como coordenador geral do Projeto Re(vi)vendo Êxodos (desde o ano de sua criação), e, contratado pela Secretaria de Educação do Distrito Federal, ministra a disciplina de História para os alunos dos $2^{\circ}$ S e $3^{\circ} \mathrm{S}$ anos do Ensino Médio do Centro de Ensino Médio Setor Leste em Brasília - DF.
} 
A exposição era imensa, com fotos enormes expostas em muitas salas e que possuíam temáticas diversificadas relacionadas a êxodo, como: migração clandestina, guerras que provocavam o êxodo como as de Ruanda e Burundi e a guerra na Iugoslávia, travessias nas fronteiras dos Estados Unidos da América, entre outras.

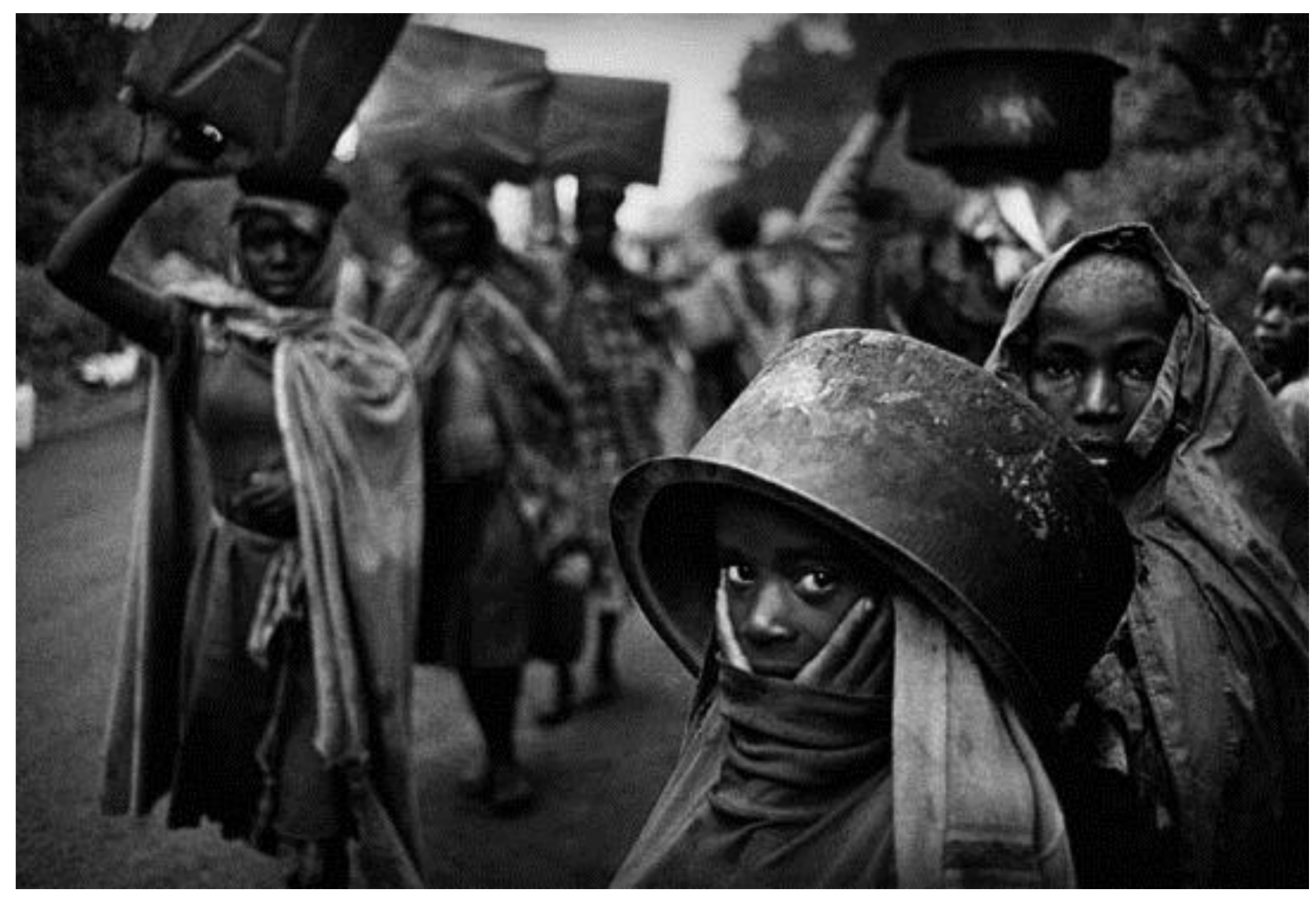

Figura 1: Fotografia de Sebastião Salgado exibida na exposição "Êxodos". (Disponível em: http://www.amazonasimages.com/travaux-exodes)

Ao planejar a atividade pedagógica que seria realizada com base na exposição, os professores decidiram pedir aos alunos que, divididos em grupos, trouxessem fotos tiradas por eles que seguissem catorze temas estipulados pelos professores e que foram escolhidos dentre as temáticas da exposição, por exemplo, mulheres no Afeganistão, guerra na Iugoslávia, migração clandestina, porém as imagens deveriam ser fotografadas dentro do Distrito Federal. O intuito era fazer com que os estudantes tivessem um olhar diferenciado para as situações comuns do cotidiano.

Iniciava-se, neste momento, a instrução à teoria e prática da Educação Patrimonial no CEM Setor Leste. 
Ao levar os estudantes a uma exposição de fotografias que captavam e representavam as realidades sociais e culturais e, posteriormente, solicitar a estes mesmos alunos que tentassem reproduzir, por meio da fotografia, seu próprio olhar diante da realidade a qual o Distrito Federal estava exposto diariamente, os professores conseguiram fazer com que os alunos observassem os fatos corriqueiros e os interpretassem de forma crítica.

Parafraseando Gastal e Moesch (2007) é fundamental que o morador da cidade decifre seus desafios para que nela mais do que apenas sobreviva, viva com qualidade. E para isto, é essencial que o sujeito olhe a cidade com cuidado explorando-a.

E assim o fizeram. Os alunos exploraram, usaram a criatividade e conseguiram levar aos professores imagens que representassem o que fora pedido. As fotos traziam, entre outras coisas, mulheres de burca, índios, tanques de guerra (encontrados no setor militar), imagens de catadores de lixo com gorros na cabeça no depósito de lixo da cidade enquanto este pegava fogo (esta imagem, sem descrição, se assemelhava muito a uma cidade em meio à guerra).

As fotos apresentadas pelos alunos eram tão interessantes que os professores decidiram expô-las no Espaço Cultural Renato Russo da 508 Sul, da Secretaria de Cultura do GDF e, assim, nomearam a exposição de "Re(vi)vendo Êxodos". A exposição foi bem sucedida e visitada por várias escolas. As pessoas que visitavam parabenizavam os estudantes que se sentiam encantados ao se verem expondo seus trabalhos fora da escola. 


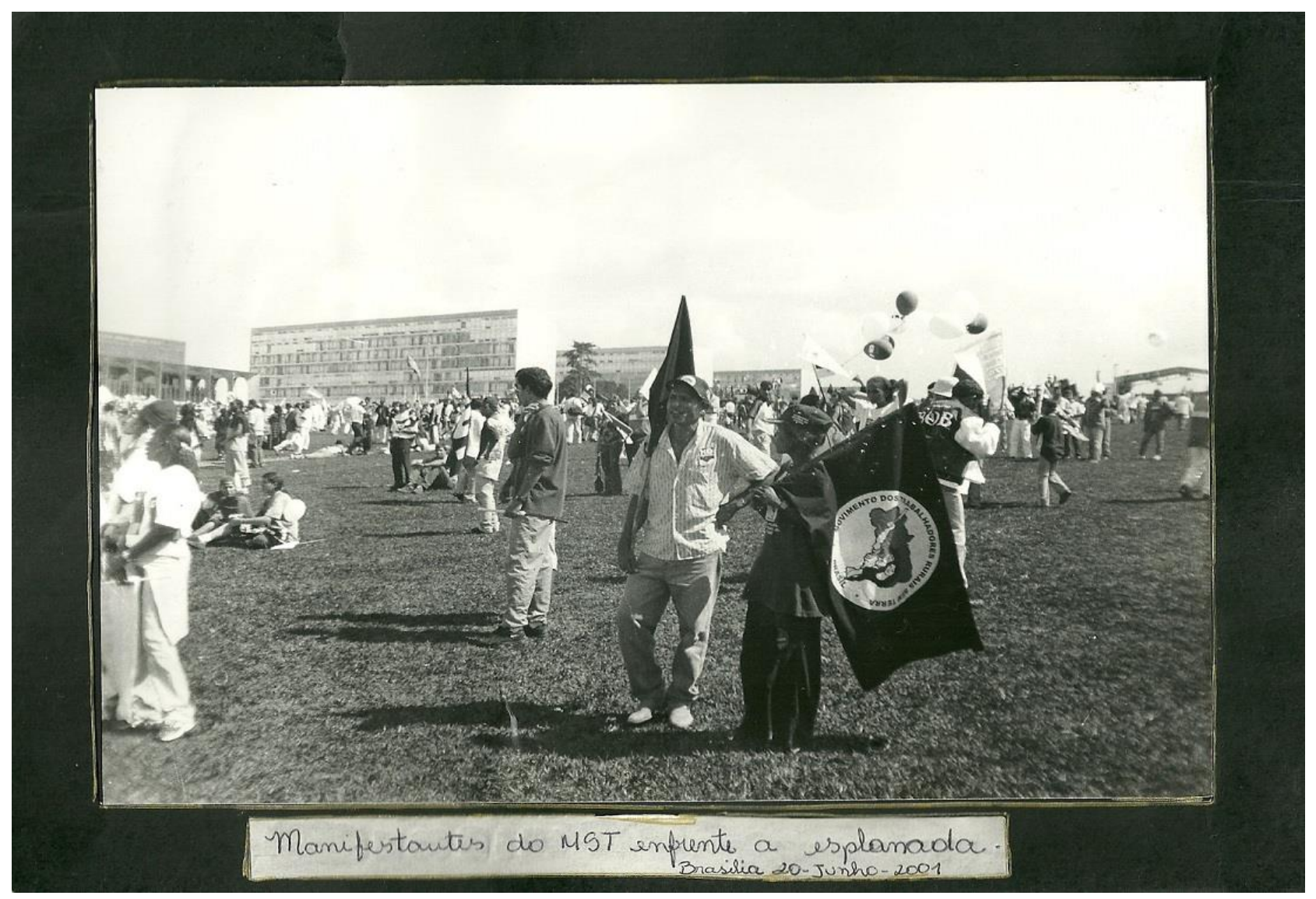

Figura 2: Manifestantes do MST (Movimento dos Sem Terra) em frente à Esplanada dos Ministérios Brasília, 20 de junho de 2001.

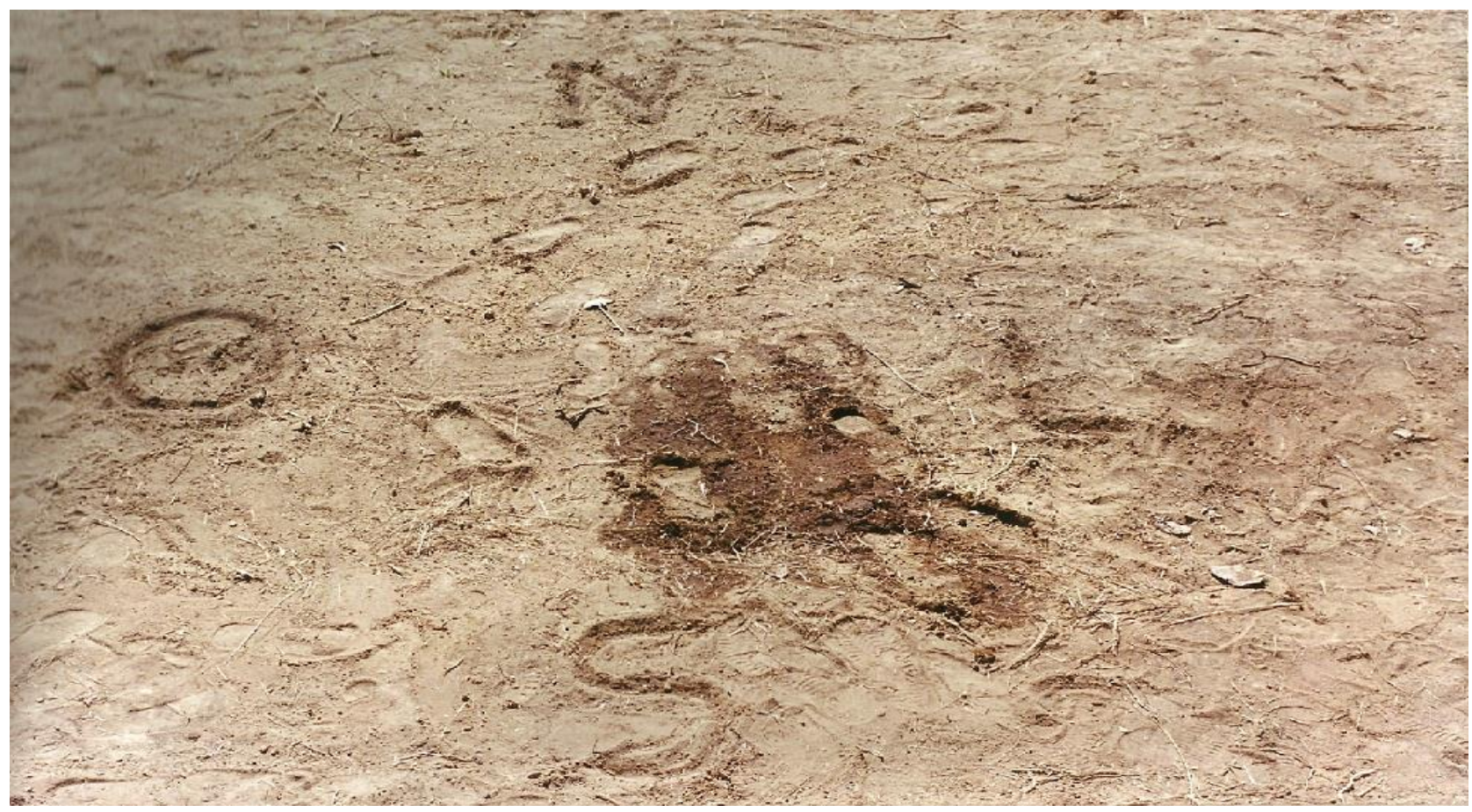

Figura 3: Imagem representativa dos pontos cardeais da Rosa dos Ventos. Capa do Cartaz de Divulgação e dos convites da primeira Exposição Re(vi)vendo Êxodos - Brasília 20 de junho de 2001. 
Naquele momento nasceu o projeto Re(vi)vendo Êxodos e, ao final de cada ano letivo, esta exposição é apresentada no mesmo local, porém agora, mais que uma exposição de fotografias, ela traz a mostra de outros produtos idealizados e confeccionados pelos alunos como vídeos e poesias.

O poema abaixo foi escrito pelos alunos do projeto Re(vi)vendo Êxodos durante uma saída técnica na noite de sábado, 24 de agosto de 2013 no distrito de Natinópolis no município de Goianésia - GO:

\section{Simplicidade}

Mais do que um substantivo,

Um adjetivo

Debaixo do pé de caju

Vista pelo chão

Germina no meu coração.

São lágrimas, sorrisos.

Pequenos olhares

Que fazem diferença nas paisagens.

Ensinando aprendemos

Sonhamos, amamos, vivemos

Ou melhor, revivemos.

Congos e Moçambiques

Unidos pela mesma fé.

Dona Socorro, Dona Conceição

Unidas pelo coração

Eis aqui tanta emoção.

Simplicidade

Norte-Sul, pelo ferro foi trazida

E pelo coração sentida

Lágrimas derramadas pela essência gerada

$\mathrm{Na}$ ferrovia chamada amor.

Eis aqui uma versão da simplicidade

Vivida nessas cidades.

Atualmente, grande parte das ações do Projeto é concretizada em conjunto pelos alunos que compartilham experiências ao realizarem pesquisas bibliográficas e de campo, com a abordagem de temas contemporâneos e o aprofundamento experimental. Constroem ao longo do ano dossiês, portfólios, vídeos, boletins informativos, cartazes, folders, encenações, desenvolvem uma monografia escolar e apresentam seminários. Ao 
longo do ano os alunos, ainda, visitam as cidades estudadas realizando entrevistas e pesquisas sobre o patrimônio imaterial dessas comunidades.

Neste contexto, nota-se que o Projeto Re(vi)vendo Êxodos trabalha e valoriza a experiência compartilhada entre os indivíduos. Desta forma, ao expor os jovens à realidade cotidiana o projeto faz com que se vejam como sujeitos históricos colocandoos na condição de indivíduos responsáveis pelas mudanças sociais e culturais a que se refere Thompson; e não como indivíduos desprendidos do mundo e a parte do momento histórico vivido.

O professor Luís Guilherme destaca a positividade no resultado do $\operatorname{Re}(v i) v e n d o$ Êxodos em relação aos alunos, e ressalta o fato de ter, hoje, mais de quarenta monitores universitários que atuam nas oficinas.

Este fato mostra que os alunos concluem o ensino médio acreditando e desejando a continuidade do $\operatorname{Re}(v i)$ vendo Êxodos, o que demonstra, ainda, que as práticas realizadas durante a participação no projeto fazem com que os jovens tenham experiências duradouras e conscientizadoras do papel de cada um como cidadão, interessados em contribuir para que o projeto cresça fomentando novas experiências.

Além disso, o coordenador destaca a relevância da caminhada que foi inserida no projeto no ano de 2004 e que, apesar de não acontecer anualmente, devido aos diversos fatores necessários para sua execução, como questões de segurança e apoio dos municípios envolvidos, traz um envolvimento ainda maior dos estudantes com o projeto.

A caminhada exige esforço físico dos alunos, assim como, entre outras coisas, três fatores que são marcantes e relembrados durante todo o percurso de aproximadamente 300 quilômetros realizados pelos estudantes durante catorze dias: "força, garra, e determinação".

O professor Luís Guilherme relembra dos depoimentos de pais de alunos que relatam como a conduta de seu (a) filho (a) mudou para melhor em relação aos afazeres domésticos, ao comportamento com a família e, até mesmo, quanto à personalidade 
após retornarem da caminhada. Destaca que a mudança no desempenho escolar destes estudantes ocorre, porém, não é tão significativa quanto à mudança pessoal, humana e poética.

\subsection{Limitações enfrentadas pelo projeto}

Ao longo dos anos, o projeto estabeleceu parecerias com instituições como o Roteiro Missão Cruls, o Clube dos Pioneiros de Brasília, o Exército Brasileiro, o IPHAN - Instituto do Patrimônio Histórico e Artístico Nacional, o Instituto Chico Mendes, Batalhão da Polícia Militar Ambiental, Corpo de Bombeiros, além de governos estaduais, administrações municipais e diversas empresas colaboradoras.

A alimentação necessária para realização de atividades mais extensas como as visitas técnicas às cidades estudadas e as caminhadas, por exemplo, são ou foram fornecidas por restaurantes parceiros como Líbanos, Beirute, Pamonhão Kalu, Camarão e Companhia, Mercado Municipal, entre outros.

Apesar de ainda contar com alguns dos parceiros mencionados, o projeto enfrenta algumas dificuldades relacionadas às limitações impostas pela burocracia a qual algumas instituições são submetidas e a baixa quantidade de professores dispostos a inserir o projeto em suas disciplinas/escolas.

O que é importante para qualquer projeto, seja ele de educação patrimonial, ambiental ou cultural, segundo o professor Luís Guilherme, é:

(...) o envolvimento específico pessoal e humano (...) o professor tem que se apropriar daquele projeto como sendo pertencente a ele. É uma questão de pertencimento. (Luís Guilherme - Professor, Setor Leste - Brasília, DF. 04 de junho de 2014).

Se em determinada escola não houver um professor que se envolva a este nível com o projeto, não tem como inseri-lo no centro de ensino em questão. Para Luís Guilherme: 
a responsabilidade de implementá-lo em sua escola. (Luís Guilherme Professor, Setor Leste - Brasília, DF. 04 de junho de 2014).

Responsabilidade esta que se relaciona, por exemplo, ao fato de ser um trabalho não remunerado e que demanda um tempo extra dos professores envolvidos.

Nestas circunstâncias cabe-se, ainda, levar em consideração, o fato de haverem professores que permanecem presos ao pensamento dicotômico proposto por Descartes e criticado por Morin e Dewey que, por este motivo, têm dificuldade de aliar a teoria aplicada em sala de aula à prática desenvolvida em projetos pedagógicos extracurriculares como o Re(vi)vendo Êxodos.

Além disso, é importante destacar que, desde a proposta que deu início ao $\operatorname{Re}(v i) v e n d o$ Êxodos, quando o professor Luís Guilherme evidencia que a atividade estipulada pela instituição durante a mudança curricular deveria ser realizada em conjunto pelos educadores, a ideia aí instituída, denota a intencionalidade da "transdisciplinaridade" o que se faz necessário retomar o pensamento complexo de Morin na relação do todo e as partes, uma vez que o autor considera que esta relação significa "reaprender a aprender" (MORIN, 2004, p. 54)

Morin esclarece que aprender é fácil, reaprender é o mais difícil, pois isto significa "mudar as estruturas do pensamento". Por este motivo esta se torna uma tarefa tão difícil e, para tanto, se necessita de alguns instrumentos de pensamento. (MORIN, 2005, p. 55).

Segundo Luís Guilherme, ocorre, ainda, que nem sempre existe uma carga horária específica para aplicação do projeto.

Com o intuito de dirimir este empecilho, algumas escolas participantes, por exemplo, aplicam-no na disciplina de PD; em outras escolas, como é o caso do Setor Leste, os professores parceiros do projeto integram-no à própria disciplina lecionada história, sociologia, geografia, física, biologia, inglês - ou, ainda, durante os intervalos das aulas. Um caso específico e interessante é o do colégio CEL (Centro Educacional do Lago) e da Escola Nova Betânia que trabalham o projeto através de oficinas ministradas 
pelos atuais monitores do projeto que, em anos anteriores, foram alunos participantes do $\operatorname{Re}(v i) v e n d o$ Êxodos.

Estas diversas modalidades do projeto se tornam possíveis devido à metodologia de aula aplicável que é apresentada pelo professor Luís Guilherme aos demais professores e monitores interessados em aplicá-lo, por se tratar de uma metodologia flexível.

Outra dificuldade em estender o projeto a outras escolas e, até mesmo, fazer com que se mantenha nas escolas atuantes é a rotatividade na profissão. Muitas das escolas mudam, por ano, de 30 a $40 \%$ o quadro de professores. Isto implica em treinamentos, atualização de treinamentos, adaptação do quadro, mudança de carga horária, adaptação à nova carga horária, etc. Para o professor Luís Guilherme este fato não só dificulta a institucionalização do projeto, mas também, provoca um verdadeiro "desastre na educação".

Contudo, quanto ao fato da institucionalização do projeto, o coordenador acredita que o melhor para a manutenção do $\operatorname{Re}(v i) v e n d o$ Exxodos é que ele conserve sua característica não-institucionalizada, uma vez que isso traz maior liberdade em sua aplicação e maior participação dos membros e com mais qualidade, visto que os professores envolvidos com o Re(vi)vendo Êxodos, apesar de não serem muitos, fazem isso por escolha própria e não por obrigação, o que, provavelmente, seria diferente caso o projeto fosse algo estipulado pelo Governo.

Neste sentido, compreende-se, ainda, que um projeto mais prazeroso para os educadores que o aplicam é, também, um projeto mais prazeroso para os alunos que dele participam, o que intensifica as experiências vividas por estes jovens. 


\section{CAPÍTULO 3:}

\section{EXPERIÊNCIAS DO ÊXODOS NA FORMAÇÃO DO TURISTA CIDADÃO}

O Re(vi)vendo Êxodos insere no cotidiano dos alunos diversas atividades e ações que aprofundam a pesquisa nos diferentes aspectos da cultura brasileira, suas expressões culturais, seus patrimônios, seu desenvolvimento científico, histórico, geográfico, sociológico e filosófico.

Antes de colocar em prática cada atividade os jovens estudantes absorvem, em sala de aula, a teoria e as orientações sobre cada aspecto que deverá ser observado na saída de campo, visita técnica ou caminhada.

Com o intuito de compreender as experiências vividas por estes jovens e na tentativa de enxergar seu desenvolvimento mediante a participação do projeto, realizouse entrevistas com dois estudantes do $2^{\circ}$ ano do Ensino Médio (Francisco Vladimir Almeida e Hérisson Duarte), duas estudantes do $3^{\circ}$ ano (Bárbara Costa e Júlia Ouriques) e quatro atuais monitores do projeto que, em primeiro momento, também foram alunos (Elizabeth Pazello, João Carlos Mendes, Pedro Victor Sousa e Rafael Gomes).

As entrevistas com os dois alunos e as duas alunas do Ensino Médio foram realizadas no Centro de Ensino Médio Setor Leste - Brasília - DF, escola precursora do Projeto Re(vi)vendo Êxodos e local onde os entrevistados estudavam, até então. As entrevistas com os quatro monitores foram feitas na Universidade de Brasília - UnB, local onde um dos monitores se graduou e os demais são graduandos.

Os alunos do Ensino Médio entrevistados foram designados pelo Professor Luís Guilherme que utilizou para critério de seleção, alunos comunicativos. Os monitores Pedro Victor e Rafael Gomes foram escolhidos pela autora desta dissertação após indicação de professores da UnB. Já os monitores Elizabeth e João Carlos foram sugeridos por Pedro Victor e Rafael. 
Destaca-se que com o intuito de padronizar o procedimento e de propor um diálogo entre os entrevistados, a primeira entrevista foi feita em dupla com os alunos Francisco e Hérisson; a segunda entrevista foi realizada em conjunto com as alunas Bárbara e Júlia; e a terceira entrevista foi realizada em duas partes: na primeira com os monitores Pedro Victor e Rafael e na segunda com os monitores Elizabeth, João Carlos e Pedro Victor. (Esta divisão da terceira entrevista ocorreu devido ao tempo que cada entrevistado dispunha para relatar suas experiências.).

Os relatos colhidos não serão apresentados em ordem cronológica dos depoimentos, mas sim agrupados por temas e apoiados das teorias que lhes complementam, uma vez que:

[...] a história que lida com relatos orais deve procurar ampliar os aportes teóricos que dão amparo às discussões e sistematizações dos procedimentos de análise próprios ao seu uso e às suas peculiaridades como fonte documental, sem, no entanto, submergir em infindáveis "considerações teóricas". (LAVERDI, [et al.], 2012, p.16).

Desta forma, o intuito é relacionar as experiências dos jovens a partir das atividades praticadas no Re(vi)vendo Êxodos com os embasamentos teóricos que fundamentam os diversos temas explorados no projeto, tanto nas atividades realizadas pelos estudantes, quanto nas tarefas atribuídas aos coordenadores e monitores do projeto e que foram explorados como base teórica para esta dissertação. São eles: Educação, Cultura, Cidadania, Identidade, Patrimônio e Educação Patrimonial. Serão analisadas ainda as experiências dos jovens na caminhada e a relação da formação de turistas cidadãos a partir do contato com as temáticas mencionadas.

\section{1 - Re(vi)vendo a Educação}

Como explanado anteriormente, um dos problemas enfrentados pelo Re(vi)vendo Êxodos relaciona-se à dificuldade de manter educadores que se interessem e incluam o projeto como parte de suas disciplinas. Quando questionados sobre a relação entre o projeto e as disciplinas convencionais os monitores Pedro Victor e Rafael esboçaram as seguintes opiniões: 
Pedro Victor acredita que muitos professores não aderem ao projeto por ele ser muito abrangente. Para ele, isso se torna uma limitação, pois depende que os professores sejam multiplicadores destes tópicos abrangentes dentro de suas próprias disciplinas. Esclarece que nem todo professor tem a abrangência que o projeto exige:

\begin{abstract}
Muitos não entendem que qualquer discussão pode incluir os temas abordados pelo projeto. Muitos não veem sentido em incluir estes temas em suas disciplinas. E se os próprios professores não veem sentido, não tem por que ser aplicado aos alunos por estes professores. (...) Outro fator questionável é que existe uma preocupação tanto dos professores quanto dos próprios alunos de que incluir determinados tópicos na disciplina de física, por exemplo, iria atrasar o desenvolvimento do conteúdo que precisava ser aplicado e visto pelos alunos para realização das provas de vestibular. (PEDRO VICTOR SOUSA, Monitor do Re(vi)vendo Êxodos, UnB Brasília, DF, 04 de novembro de 2014, 15:00h).
\end{abstract}

Rafael acredita que apenas o estudo dos temas propostos pelo projeto junto às disciplinas tradicionais, não é suficiente. Considera as saídas de campo extremamente importantes, pois é só a partir delas que o aluno vai enxergar de verdade a relação do conteúdo introduzido em sala de aula com o projeto.

As saídas de campo são, também, fundamentais para o êxito da Educação Patrimonial, uma vez que, só por meio do contato direto com o Patrimônio Cultural é que os alunos poderão passar por experiências que lhes façam compreender o significado do Patrimônio para o grupo social ao qual ele pertence.

Rafael esclarece, ainda, que só após a saída de campo o aluno vai compreender a importância de elaborar um folder ou um dossiê previamente, estudar a constituição, violência doméstica, os direitos civis, para depois ir a campo. Exemplifica:

Até terem uma experiência mesmo, uma vivência por meio de uma pesquisa de campo e tal, os alunos não percebem que isso (o que é visto em sala) tá ligado diretamente ao projeto, entende? Então... Por isso a gente tem que sair um pouco mais das quatro paredes da sala de aula. (...) Até então fica muito chato só em sala de aula, só pesquisa. Ainda para os alunos verem o que é útil, essa ideia de utilidade: - Ah! Agora faz sentido por que que eu estudei a constituição, por que que eu estudei a violência doméstica num debate pra hoje eu compreender "tá" numa determinada sociedade(...). (RAFAEL GOMES, Monitor do Re(vi)vendo Êxodos, UnB - Brasília, DF, 04 de novembro de 2014, 15:00h). 
As saídas de campo, após o contato com a teoria aplicada em sala de aula, também auxiliam a compreensão do aluno quanto ao seu papel como cidadão, uma vez que, ao ser estimulado a refletir sobre determinadas temáticas ao chegar a campo o aluno estará mais atento aos fatos sociais associados às teorias trabalhadas em sala e, desta forma, compreenderá as raízes sociais que levaram determinada comunidade a passar por específicos problemas.

Rafael exemplifica com uma saída de campo a uma determinada comunidade do Goiás que tenha violência, criminalidade e outras características sociais muito presentes que, só é possível a compreensão do aluno, se presenciar aquela determinada realidade após ter estudado em sala de aula os tópicos anteriormente abordados. Continuando a explanação, Rafael relata:

Então isso, se é visto pelos alunos também pode ser visto pelos professores: Ah! Como que eu vou relacionar química com o projeto? - Muitos professores perguntam também: - Como eu posso contribuir? (RAFAEL GOMES, Monitor do Re(vi)vendo Exxodos, UnB - Brasília, DF, 04 de novembro de 2014, 15:00h).

Segundo Rafael, essa preocupação em saber como incluir as áreas de atuação do projeto em sua disciplina, não vale apenas para os professores. Os monitores também tem que compreender e encontrar métodos de inserir os seus estudos da graduação no projeto. Como retribuir dialogando seus cursos com o projeto. Para os monitores isto já se tornou algo natural, sempre tentar aproximar sua área de atuação profissional com o projeto, devido aos diversos diálogos que têm entre si e com o professor Luís Guilherme e também à experiência de grupo, isto se tornou muito presente.

Contudo, eles têm cautela ao falar sobre esse encontro de olhares que consegue aproximar as humanas, as exatas, códigos e linguagens, pois sabem que virou moda falar de transdisciplinaridade ${ }^{7}$ para obter recursos. Mas mesmo com esse modismo, verifica-se que existem professores que ainda tem esse desafio de não conseguir

\footnotetext{
${ }^{7}$ Entende-se por disciplinaridade: a análise da realidade a partir de um único fragmento/ângulo específico; estudo unilateral da realidade;

Multidisciplinaridade: Tema específico estudado por diversas disciplinas sem haver interação entre estas disciplinas;

Interdisciplinaridade: Integração entre diferentes disciplinas de forma articulada para se analisar uma determinada realidade por meio da totalidade, gerando novos conhecimentos;

Transdisciplinaridade: Inserção de abordagens próprias de uma disciplina dentro da estrutura de outra ou em um novo contexto com o intuito de analisar realidades complexas. (BASTOS, 2004)
} 
enxergar fora da utilidade de suas disciplinas, não conseguem compreender que temas gerais da sociedade podem ser incorporados dentro do seu conteúdo aplicado.

A experiência compartilhada entre educadores é um fator que pode auxiliar exponencialmente na busca da educação transdisciplinar, o que é o caso dos monitores do Projeto Re(vi)vendo Êxodos. Contudo, há de se levar em consideração que apesar da compreensão de que toda verdadeira educação se realiza mediante a experiência, não significa que todas as experiências são igualmente verdadeiras ou educativas. (DEWEY, 1939). Desta forma, é imprescindível, para o resultado positivo da experiência, que esta seja reflexiva.

Entende-se por experiência reflexiva, o ato de se pensar sobre esta experiência antes, durante e depois do momento em que esta ocorre se atentando, após este processo, para a aquisição de novos conhecimentos e resultados. (WESTBROOK, 2010). A experiência reflexiva deve ser estimulada pelo educador no processo educativo, assim, com o passar das experiências o educando vai adquirindo os conhecimentos necessários para direcionar da melhor forma suas experiências futuras. A prática da experiência reflexiva é um processo de educação e reeducação, o sujeito vai se educando e reeducando a partir do sucesso em suas experiências.

Pedro Victor acredita que se houvesse a aplicação da transdisciplinaridade desde a educação infantil haveria uma facilidade maior de os professores apoiarem este tipo de formação onde todas as coisas dialoguem.

Felizmente para o $\operatorname{Re}(v i) v e n d o$ Êxodos, nas escolas onde o projeto é aplicado, existem aqueles professores que são favoráveis a união da teoria e da prática em benefício do aprendizado de qualidade.

Paulo Freire em seu livro "Pedagogia da Autonomia - Saberes necessários à prática educativa" aborda conhecimentos que considera indispensáveis à prática docente de educadores críticos, progressistas. O autor não dirige esses saberes exclusivamente aos educadores críticos, apenas acredita que para estes tais conhecimentos são indispensáveis. . 
Os saberes contidos no livro de Freire derivam de uma reflexão crítica sobre a prática, no sentido de se alinhar a relação Teoria/Prática para que a primeira não se torne um "blá-blá-blá" e a segunda um ativismo (FREIRE, 2014, p.24).

Após análise das características pedagógicas do Re(vi)vendo Êxodos nota-se grande semelhança entre o trabalho realizado pelos professores que aderem ao projeto e vários dos saberes citados por Paulo Freire.

Um dos saberes explicitados por Freire é: "Ensinar exige rigorosidade metódica" (FREIRE, 2014, p. 28). Com isso o autor aborda a necessidade de o educador estimular o pensamento crítico do educando. Este deve conduzir o educando a criar, instigar, ter inquietude, ser rigorosamente curioso e persistente.

Em entrevista aos já mencionados participantes do Re(vi)vendo Êxodos, em resposta a três diferentes perguntas, obteve-se como informação dos entrevistados respostas muito semelhantes quanto ao fato de os alunos serem estimulados a observar e pensar sobre coisas que antes não davam importância.

A pergunta feita aos alunos do $2^{\circ}$ ano do Ensino Médio foi "Até este momento, o que vocês tiram de maior aprendizado do projeto?". As respostas obtidas foram:

Eu tenho certeza que é a descoberta de coisas que a gente não sabia que tinham no nosso lugar. (HÉRISSON DUARTE, aluno do $2^{\circ}$ ano, Setor Leste - Brasília - DF, 21 de outubro de 2014, 09h30min).

Vladimir, olhando para Hérisson, indagou:

É! Sair da zona de conforto né. (FRANCISCO VLADIMIR, aluno do $2^{\circ}$ ano, Setor Leste - Brasília, DF, 21 de outubro de 2014, 09h30min).

$\mathrm{O}$ questionamento feito às alunas do $3^{\circ}$ ano do Ensino Médio foi: " $O$ que vocês vêm de mudança pessoal desde que começaram o projeto?". As informações relatadas foram: 
Ajuda muito a gente tanto no dia-a-dia, que a gente passa a observar mais as nossas atitudes, como no modo que a gente trata o nosso patrimônio, tanto material, quanto imaterial. (...) Eu vi que eu cresci muito no meu senso crítico e nas questões de observação, tanto pra fazer relatórios (...) Eu vejo que eu cresci muito com o projeto em relação a isso. É um projeto muito rico! (BÁRBARA COSTA, aluna do $3^{\circ}$ ano, Setor Leste - Brasília, DF, $10 \mathrm{~h} 30 \mathrm{~min})$.

A gente (Júlia e Bárbara) se interessa por coisas novas, a gente está engajada no ambiente escolar e tal, mas como o Luís Guilherme sempre provoca a gente: 'Estando no meio onde a gente está é inevitável que a gente fique um pouco alienado com as coisas que são oferecidas na mídia o tempo todo, nas ruas, etc.' E o Êxodos é uma coisa que tira a gente dessa zona de conforto. Então eu acho que com o Exxodos, por ser obrigado a pesquisar essas coisas a gente acaba se interessando por coisas novas. (...) Isso foi uma coisa que me marcou muito no Exxodos, por serem coisas que tocam a gente profundamente. O Êxodos propõe questões muito profundas. Questões

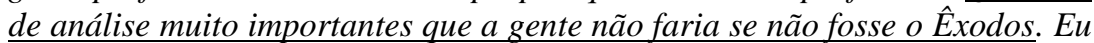
acho que foi nisso que o Exxodos me mudou. Não que eu não fosse uma pessoa interessada pela sociedade antes, por que eu sempre fui, sempre procurei coisas novas, mas o Exodos foi mais uma passagem pra isso.". (JÚLIA OURIQUES, aluna do $3^{\circ}$ ano, Setor Leste - Brasília, DF, 10h30min).

Ele (o Exodos) meio que tira o roteiro do seu dia-a-dia. Você acorda e faz. isso ou aquilo e é tudo muito monótono. E com o $\hat{E} x o d o s$ você sai dessa rotina, você acaba vendo outras coisas que você não via antes. (BÁRBARA COSTA, aluna do $3^{\circ}$ ano, Setor Leste - Brasília, DF, 10h30min).

A partir dos depoimentos listados dos quatro alunos verificam-se aspectos desta "rigorosidade metódica" da qual Paulo Freire trata. Em resposta às diferentes perguntas os estudantes citaram questões como: descoberta de coisas, sair da zona de conforto, crescimento no senso crítico e observação, análise das coisas e sair da rotina. Todos estes elementos que representam a descoberta de uma nova percepção, de um novo olhar.

É importante compreender que Freire trata do estímulo ao senso crítico, o estímulo desse novo olhar, uma vez que "o ser humano é por natureza um ser criativo. No ato de perceber, ele tenta interpretar e, nesse interpretar, já começa a criar". (NOVAES [et al], 1988, p.167).

Ao solicitar aos monitores que traçassem uma pequena retrospectiva da vivência deles como alunos no projeto, as experiências narradas foram semelhantes aos relatos dos alunos quanto ao novo olhar. Pedro Victor esclarece que:

(...) o projeto dá uma "cutucada". Faz com que se abra a visão para as coisas que o aluno não via como importante e que tem a ver com o que cada 
um é e onde cada um habita. (PEDRO VICTOR SOUSA, Monitor do Re(vi)vendo Êxodos, UnB - Brasília, DF, 04 de novembro de 2014, 15:00h).

Sobre este "cutucar" do qual Pedro Victor trata, Rafael Gomes ressalta que, em primeiro momento, se tornou monitor do projeto justamente por possuir interesse em manter um compromisso de cidadania de querer ajudar e retribuir, cutucar outros alunos, "acordar a galera". Depois se tornou paixão mesmo pelo projeto de vida, pois deseja saber sempre como pode contribuir ainda mais. Rafael Sente que mudou bastante com sua experiência com o projeto. Para ele o "Êxodos" abriu ainda mais o horizonte de expectativas e perspectivas diferenciadas. Afirma:

A partir do momento que o aluno tem contato, numa pesquisa de campo, sai daqui, vai pra uma outra cidade, tem contato com atividades culturais, com pessoas de um outro lugar... eu acho que isso trabalha um tanto com a sensibilidade do aluno, e mostra outros fatos que, até então, ele desconhece. Então isso fez com que eu enxergasse o mundo um tanto diferente (...) por conta desse 'olhar diferenciado' que caminha junto à formação complementar que o projeto oferece. (RAFAEL GOMES, Monitor do Re(vi)vendo Exxodos, UnB - Brasília, DF, 04 de novembro de 2014, 15:00h).

Este novo olhar é qualidade do cidadão que dotado de experiências compartilhadas com outros sujeitos tanto do local que habita, quanto de outras cidades, apodera-se do lugar em que vive com intenções além de apenas morar, mas prezando por observá-lo apreciando e valorizando suas qualidades e promovendo ações que possibilitem a mudança do que não está adequado.

Rafael fala, também, sobre as pesquisas feitas em outras cidades, o que representa a prática da experiência turística. Ao falar sobre o contato que os alunos têm com "outra cidade", "atividades culturais" e "pessoas de um outro lugar" remete à definição proposta por Moesch quanto ao Turismo se tratar de "um campo de práticas histórico-sociais" (MOESCH, 2004). Desta forma, durante estas práticas os participantes do Êxodo vivenciam, também, a experiência turística.

João Carlos afirma que antes de ter contato com o projeto tinha uma visão superficial sobre a cidade. Não conseguia observar a diversidade cultural que a cidade possui. A partir da participação no projeto e, com isso, a partir das saídas para o entorno 
do Distrito $\mathrm{Federal}^{8}$, conheceu realidades que não conhecia que não são contadas no livro, tinha sua própria leitura sobre a cidade. Passou por um processo de amadurecimento. Como monitor, tenta contribuir para que outras pessoas passem por este amadurecimento também, pois acredita que assim elas possam se sentir independentes, livres para compreender as coisas, "quebrando" a questão de apenas uma visão, um olhar, fugindo do conhecimento convencional. João Carlos esclarece sobre a visão que tinha de Brasília antes de participar do Re(vi)vendo Êxodos:

A partir do momento que a gente começa a discutir Brasília e discutir o DF e o Entorno, numa perspectiva de que aqui existe história, que tem história, é muito diferente a sua visão sobre isso. Eu lembro que eu olhava... Assim, eu achava tudo muito ah... superficial né? Eu não tinha essa visão que... De que aqui já existia muita coisa antes né? Que Brasília não é só de '70' pra cá né? Então eu acho que depois que a gente teve esse contato com o Projeto, com essa perspectiva de que: Sim! Aqui tem história e sempre teve!... Não é só por que depois que criou-se tudo... E até pra (pausa). Me identificar mesmo com a cidade, por que eu acho que não me identificava e até hoje eu ainda tenho uma certa dificuldade com isso. Acho que é muito contraditório e o contraste é muito forte né? Mas eu precisei entrar no Projeto pra ver isso. Eu não conseguia enxergar essa diferença né, que a gente tem. (...) Acho que é cultural também. (pausa) Caldeirão de tudo né? Da diversidade que a gente tem aqui em Brasília. Brasília... DF né, na verdade. (...) Então a minha relação, eu acho que a partir desse momento... (...) Internalizando né? Indo pro entorno, aí é que foi mais um choque mesmo né? Eu me senti, realmente, como um cidadão do DF e, também, ao mesmo tempo, do entorno né? Do Goiás né? Por que aí a gente já teve um convívio maior com as cidades que estão ao redor do DF e conhecendo, mesmo, realidades que, até então, eu desconhecia. E que muitas vezes essa história não é contada nos livros né? Eu acho que isso é a questão principal, você aprender a ler no cotidiano. É outra leitura né? A gente tem lá o livro que tem a história contada daquela forma, e aí tem outra leitura né? Que é a leitura a partir da sua realidade, como você se identifica (...). É a questão mesmo de você trabalhar coisas que o projeto busca né? Nossa identidade, aproximações, onde nós estamos. E aí foi que os meus olhares já se misturaram um pouco, algumas crises aí, mas (risos) eu acho que faz parte do processo de amadurecimento. E eu vejo isso, claramente, assim, também, quando a gente... Por que é engraçado, quando a gente é aluno é gente sofre o baque né, depois... Quando a gente já volta como monitor, que a gente passou por esse processo, a gente tenta ao máximo buscar também, com que os alunos também, tenham um pouco isso né? Quebra essa questão de uma visão, um olhar... E aí é muito bacana também. Como monitor também, tem essa perspectiva de que você tá contribuindo com que outras pessoas também abram um pouco a sua visão, ou seja, que sintam-se autônomos, independentes, livres, saindo um pouco da... (...) do conhecimento tradicional né? Convencional na verdade. (JOÃO CARLOS MENDES, Monitor do Re(vi)vendo Êxodos, UnB - Brasília, DF, 04 de novembro de 2014, 15:00h).

${ }^{8} \mathrm{O}$ entorno do qual João Carlos trata se refere à Região Integrada de Desenvolvimento do Distrito Federal e Entorno (RIDE). Estas regiões são municípios representados pelas administrações do DF e cidades do Goiás. (Sudeco - Superintendência do Desenvolvimento do Centro-Oeste). 
Elizabeth relata que sempre foi muito observadora, desta forma, a participação no projeto pode aprimorar seu olhar a partir da proximidade com as diferentes realidades que conheceu para que pudesse ter uma percepção que compreendesse, reconhecesse e valorizasse o todo do lugar que visitava. Ao mesmo tempo em que via as diferenças conseguia encontrar também similaridades entre as novas realidades que conhecia e sua própria realidade. Elizabeth esclarece:

Eu sempre tive um pouco de ser muito observadora assim né? Com relação às pessoas, essa diferença... Olhar mesmo a paisagem. Eu tinha um pouco disso tudo (...). E com o Projeto eu acho que vendo algumas realidades de outras cidades eu consegui aplicar assim... Não aplicar, mas perceber essa mesma realidade aqui em Brasília. Aqui em Brasília e no entorno também. (...) Não é muito diferente assim, algumas realidades, você começa a observar, tanto cultural... (...) Eu acho que aprimorou o meu olhar pra algumas realidades assim, que eu só observava, mas que você não tinha, sei lá, talvez um... Não sei... Uma percepção mesmo mais assim... Sei lá, mais, próxima sabe? Por que quando você vivencia (...) você tem esse contato mais próximo, você começa a observar isso nos lugares e a reconhecer e talvez dá mais importância pra esse lugar. A partir do momento que eu tô mais próxima eu consigo valorizar aquilo e... Compreender também o todo né? Como é essa diferença de classe, diferença, sei lá, de cultura. Como é que é essa questão de respeito... (ELIZABETH PAZELLO, Monitora do Re(vi)vendo Êxodos, UnB - Brasília, DF, 04 de novembro de 2014, 15:00h).

Os depoimentos mencionados remetem a rigorosidade metódica tratada por Freire que é nitidamente praticada pelos educadores do $\operatorname{Re}(v i) v e n d o$ Exxodos e ainda remetem ao posicionamento do autor quanto ao significado de "ensinar" quando esclarece que "ensinar não é transferir conhecimento, mas criar as possibilidades para sua própria produção ou a sua construção.” (FREIRE, 2014, p. 47) (Grifo do autor), posto que é clara a vivência e prática do discurso proposto pelas diretrizes do projeto.

A metodologia nada convencional do Re(vi)vendo Êxodos é explicitada nos depoimentos dos entrevistados e mostra a flexibilidade dos coordenadores e professores para a renovação de temas e atividades propostas aos estudantes do projeto. Dentre esta renovação destacam-se as atividades que são praticadas fora do ambiente convencional de ensino capazes de propor experiências informais e únicas que possibilitam que os alunos descubram e reconheçam sua identidade como sujeitos daquele determinado meio social.

Freire aponta o seguinte saber "ensinar exige o reconhecimento e a assunção da identidade cultural". (FREIRE, 2014, p. 41). Dito isso, esclarece: “Assumir-se como ser 
social e histórico, como ser pensante, comunicante, transformador, criador, realizador de sonhos, capaz de ter raiva porque capaz de amar." (FREIRE, 2014, p. 42).

Ao relatarem o amadurecimento que tiveram em relação à forma de observar e criticar as coisas a partir da participação no Re(vi)vendo Êxodos, os entrevistados demonstram a analogia entre a experiência vivida nas atividades praticadas fora do ambiente formal de ensino e a "assunção da identidade cultural" esclarecida por Freire.

\section{2 - Re(vi)vendo a Cultura}

As questões sociais e culturais são, provavelmente, os fatores de maior foco e mais relacionados às atividades desenvolvidas no Projeto Re(vi)vendo Êxodos. Logo em sua síntese, descrita em documento produzido e fornecido pelo Coordenador Geral do Projeto, Luís Guilherme, apresenta-se como objetivo geral: "Desenvolver as ações que permitam aos alunos pesquisar, entrevistar e conhecer sua Identidade, o Meio Ambiente, a Missão Cruls e o Patrimônio cultural e Regional.".

Nota-se pelo objetivo do Projeto que se depender do Re(vi)vendo Êxodos os jovens que dele participam não serão afetados pelo "líquido mundo moderno" ao qual o autor Zygmumt Bauman se refere ou, ao menos, serão pouco afetados. Ao contrário do fluxo volúvel que seguem as relações líquidas, o Projeto Êxodos trabalha para que os jovens consigam se descobrir e construir suas identidades através das experiências de forma sólida e coesa, conhecendo outras culturas e compartilhando similaridades e diferenças.

Durante o ano letivo os professores participantes do Êxodos estipulam aos alunos diversas atividades que exigem pesquisas fora do ambiente escolar onde os alunos devem visitar cidades satélites do Distrito Federal e outras cidades localizadas no entorno do DF. Essas saídas para pesquisa aproximam os alunos da realidade vivida por outras comunidades, expandem suas possibilidades de interação social, ampliam seus interesses culturais e aprofundam o conhecimento quanto ao próprio local onde moram. 
Ao serem questionadas se o Projeto Re(vi)vendo Exodos interferiu em suas opções profissionalizantes as estudantes dos $3^{\circ}$ ano dialogaram e responderam que este interveio em muito mais do que apenas as escolhas profissionais:

Com certeza! Por que é isso que a gente falou antes, o Exxodos não 'tá' alheio à nossa vida, é uma coisa super integrada na nossa sociedade. (...) Eu não tenho certeza se eu quero fazer cinema, uma das minhas outras opções é arquitetura, também influenciada pelo Êxodos. E o Exxodos eu acho que... Me ajudou a me construir como pessoa, a me identificar. A me identificar com a minha cultura, a pesquisar minha cultura e a cultura de outras pessoas... E isso com certeza influenciou nas minhas escolhas. (JÚLIA OURIQUES, aluna do $3^{\circ}$ ano, Setor Leste - Brasília, DF, 10h30min).

Exatamente! Por isso que quando alguém vira pra você e pergunta: - Quem você é? - Aí a primeira coisa que você vai fazer é falar seu nome, mas... E o resto? A sua história, a sua identidade, a sua família, as suas raízes culturais? Você não sabe! E aí essas coisas é que induzem a pesquisar. (BÁRBARA COSTA, aluna do $3^{\circ}$ ano, Setor Leste - Brasília, DF, 10h30min).

Inclusive o primeiro trabalho do Exxodos esse ano foi escrever uma redação sobre identidade: - 'Quem é você?'. E aí teve gente que escreveu uma página só, teve gente que escreveu mais, mais profundo. A gente tinha que falar de uma tradição na nossa família e tal. (JÚLIA OURIQUES, aluna do $3^{\circ}$ ano, Setor Leste - Brasília, DF, 10h30min)

Assim, pra mim o Exxodos influenciou muito. Por que você tem uma mente muito fechada quanto ao que você vai fazer... O Exxodos te propicia ver outras formas. Então eu me encontrei na Geografia e me encontrei no Êxodos e pronto. Me achei! Agora eu sei quem eu sou! (BÁRBARA COSTA, aluna do $3^{\circ}$ ano, Setor Leste - Brasília, DF, 10h30min).

Júlia e Bárbara explicam que o Projeto incentivou a conhecerem culturas diferentes e a própria cultura, o que influenciou em suas escolhas. Muitos dos entrevistados relataram que conheciam muito pouco ou nada da cidade satélite onde moravam e do DF como um todo antes de participar do Re(vi)vendo Êxodos.

A socióloga Luciana Teixeira de Andrade em seu artigo "Cultura, Cidade e Cidadania" explica que:

A cidadania institui um código comum de direitos e, ainda que certas diferenças hierárquicas permaneçam, como as desigualdades entre as classes sociais, raça e gênero, a cidadania significa que, apesar disso, os cidadãos compartilham os mesmos direitos e deveres. A liberdade e a diversidade presentes nas cidades só fizeram expandir esses direitos. (ANDRADE, 2009, p. 2). 
Dois entre muitos destes direitos do qual a autora aborda são: o "direito à cidade" e o "direito de ter acesso à cultura nas suas mais diversas formas". Entretanto, nem todas as pessoas que vivem nas cidades desfrutam igualmente do direito à cidade, bem como nem todos que nela vivem têm acesso à cultura nas suas mais diversas formas.

Contudo, para Andrade, da mesma forma que a cidadania pressupõe estes direitos eles devem, também, ser praticados: “(...) os cidadãos precisam ter conhecimento e condições de exercê-los. A garantia legal é um passo que precisa der completado com o exercício, a prática do direito." (ANDRADE, 2009, p. 3).

O Re(vi)vendo Êxodos estimula os alunos, de forma persistente, a conhecerem centros culturais, museus, exposições de arte, teatro, música, além de locais de manifestações específicas de religião e outros grupos e instituições culturais e sociais mais reservados. Sendo assim, o Projeto incentiva os alunos a conhecerem seus direitos como cidadãos e a exercê-los plenamente. A autora afirma, ainda, que:

\footnotetext{
Por fim, o espaço é um elemento fundamental da identificação dos cidadãos com as cidades, seja nos seus espaços públicos, como as praças e os parques, nas suas construções referenciais das várias formas de viver, nos espaços do bairro ou mesmo nas suas moradias. Na construção da nossa identidade vários sentidos desempenham o papel de nos ligar às pessoas, às coisas e aos acontecimentos, mas o espaço é um dos principais. É por meio da lembrança dos lugares que as nossas experiências se fixam na memória e na nossa sensibilidade. Pertencer a uma cidade, a um estado ou a uma nação não é apenas uma condição legal, mas principalmente o compartilhamento de experiências e de vivência dos lugares. Disso decorre a importância de se preservar. (ANDRADE, 2009, p. 3).
}

Os entrevistados, de forma geral, explicam que o Re(vi)vendo Êxodos provoca os alunos a procurarem saber sobre suas origens e que ao visitarem determinadas cidades se surpreendem com o desconhecido, o que aguça a vontade de saber mais sobre outras cidades. Afirmam que antes do Re(vi)vendo Êxodos pensavam de forma preconceituosa em relação a determinadas manifestações culturais que, a princípio, contradiziam suas crenças. Pensavam, ainda, de forma temerosa sobre certas localidades desprivilegiadas do DF onde o índice de criminalidade registrado pelos órgãos oficiais é preocupante. 
O autor Zygmunt Bauman em seu livro "Confiança e medo na cidade" retrata esta questão da falta de segurança da sociedade em relação à vida nas cidades. Baseado na "lógica factual" de Sigmund Freud, Bauman esclarece que este medo sofrido pela sociedade é uma "miséria de origem social" (BAUMAN, 2009, p. 2). Sendo assim, este é um sofrimento criado pela própria sociedade moderna que ao se enxergar impotente na sua tentativa frustrada de buscar por uma completa e inabalável proteção e segurança, determina que este fracasso se deva à existência de algum delinquente. Em sequência, Bauman esclarece:

Poderíamos dizer que a insegurança moderna, em suas várias manifestações, é caracterizada pelo medo dos crimes e dos criminosos. Suspeitamos dos outros e de suas intenções, nos recusamos a confiar (ou não conseguimos fazê-lo) na constância e na regularidade da solidariedade humana. Castel atribui a culpa por esse estado de coisas ao individualismo moderno. Segundo ele, a sociedade moderna - substituindo as comunidades solidamente unidas e as corporações (que outrora definiam as regras de proteção e controlavam a aplicação dessas regras) pelo dever individual de cuidar de si próprio e de fazer por si mesmo - foi construída sobre a areia movediça da contingência: a insegurança e a idéia de que o perigo está em toda parte são inerentes a essa sociedade. (BAUMAN, 2009, P.2).

Bauman retrata, nestas condições, a sociedade moderna e líquida da qual discorre em outras de suas obras. Para ele, em determinado momento, a sociedade se divide em dois "mundos-de-vida" segregados. Quanto aos sujeitos do primeiro mundode-vida o autor esclarece:

As pessoas da "primeira fila" não se identificam com o lugar onde moram, à medida que seus interesses estão (ou melhor, flutuam) em outros locais. Pode-se supor que não adquiriram pela cidade em que moram nenhum interesse, a não ser dos seguintes: ser deixadas em paz, livres para se dedicar completamente aos próprios entretenimentos e para garantir os serviços indispensáveis (não importa como sejam definidos) às necessidades e confortos de sua vida cotidiana. A gente da cidade não se identifica com a terra que a alimenta, com a fonte de sua riqueza ou com uma área sob a sua guarda, atenção ou responsabilidade, como acontecia com os industriais de idéias e bens de consumo do passado. Eles não estão interessados, portanto, nos negócios de "sua" cidade: ela não passa de um lugar como outro e como todos, pequeno e insignificante, quando visto da posição privilegiada do ciberespaço, sua verdadeira - embora virtual - morada. (BAUMAN, 2009, p.9)

Em relação aos que pertencem ao segundo mundo, Bauman afirma: 
O mundo-de-vida dos outros, dos cidadãos da "última fila", é exatamente o contrário. Em geral, para defini-lo, diz-se que está fora das redes mundiais de comunicação com as quais as pessoas da primeira fila vivem conectadas e com as quais sintonizam suas próprias vidas. Os cidadãos da última fila estão "condenados a permanecer no lugar". Portanto, espera-se que sua atenção cheia de insatisfações, sonhos e esperanças - dirija-se inteiramente para as "questões locais". Para eles, é dentro da cidade em que moram que se declara e se combate a luta - às vezes vencida, mas com maior freqüência perdida para sobreviver e conquistar um lugar decente no mundo. (BAUMAN, 2009, p.10)

O Projeto Re(vi)vendo Êxodos mostra-se como propulsor de indivíduos que compreendem o valor do interesse em relação ao local que habitam, bem como, às demais comunidades que estão à sua volta.

Ao questionar os alunos do $2^{\circ}$ ano sobre o que mudou pessoalmente após participarem do projeto esclareceram:

"Acho que agora a gente vai nas outras cidades e tem um outro olhar" (...) o olhar do que que realmente importa." (FRANCISCO VLADIMIR, aluno do $2^{\circ}$ ano, Setor Leste - Brasília, DF, 21 de outubro de 2014, 09h30min).

Às vezes a gente vai numa outra cidade, olha e pensa: - Uai, a nossa também é parecida com isso! Nossa, na deles também fazem isso! Olha, eles também não são tão desorganizados! Nem todo mundo morre lá! (risos) Entendeu? Nem todo mundo é tão ruim! (HÉRISSON DUARTE, aluno do $2^{\circ}$ ano, Setor Leste - Brasília - DF, 21 de outubro de 2014, 09h30min).

Os alunos ainda esclarecem que antes do projeto só iam a eventos de música e ao teatro, contudo, após terem ido a uma exposição com o professor e os demais alunos da turma frequentam muitas exposições de fotografias e arte em geral. A partir desta informação, os alunos foram questionados quanto ao que analisavam quando visitavam estas exposições:

Ah, acho que a gente tenta encontrar o que ele (o professor Luís Guilherme) pede 'né'! Patrimônio, cidadania e qualidade de vida. Eu gosto mais de procurar identidade! (FRANCISCO VLADIMIR, aluno do $2^{\circ}$ ano, Setor Leste - Brasília, DF, 21 de outubro de 2014, 09h30min).

Eu já viajo! Eu já fico olhando lá e... Tento ver o que aquilo significa, o que o cara tentou, ficou pensando quando 'tava' tirando a foto, quando 'tava' pintando. Isso muda muito... (...) 'que nem' quando a gente tem que entrevistar. Aí os meninos do meu grupo sempre escolhem alguém da cidade deles 'né'! E eu: - Não, vamos escolher uma coisa diferente! Aí a gente teve que entrevistar pessoas que a gente não conhecia, então foi muito diferente! 
(...) a maioria já escolhe cidades que conhece alguém já pra entrevistar, pra ser coisa mais fácil, entendeu?! (HÉRISSON DUARTE, aluno do $2^{\circ}$ ano, Setor Leste - Brasília - DF, 21 de outubro de 2014, 09h30min).

Mas a gente também foi na minha cidade, na Vila Telebrasília! E aí foi bom, por que eu já conhecia e fiquei sabendo até mais! (FRANCISCO VLADIMIR, aluno do $2^{\circ}$ ano, Setor Leste - Brasília, DF, 21 de outubro de 2014, 09h30min).

Ao perguntar às alunas do $3^{\circ}$ ano sobre a relação que tinham com a cidade onde moram explicaram:

A gente mora na Asa Sul, inclusive, somos vizinhas. Para mim sim. Eu não sou de Brasília. Eu sou de Florianópolis. Então quando eu cheguei aqui, a imagem que a gente tinha das cidades satélites era uma imagem de muita violência, de precariedade, de periferia e tal. (...) Como eu entrei em escola pública aqui em Brasília, isso ajudou a mudar muito minha visão. E o $\hat{E x o d o s}$ me ajudou ainda mais, por que obriga a gente a olhar de uma forma não preconceituosa, de uma forma verdadeira. Você vai lá e você conversa com as pessoas da cidade. E outra coisa que aconteceu também é que o Luís Guilherme sempre 'tava' mandando a gente ir em outros lugares (...) eu acho que eu me engajei mais com o ambiente. Passei a ir mais, com mais frequência nos lugares, procurar lugares novos, mesmo os que não estavam sugeridos no Exxodos e mudar a minha visão sobre muitas coisas que eu não sabia sobre a cidade. Principalmente pra mim que sou de fora, que não conhecia direito, o Exxodos me ajudou muito a conhecer isso aqui tudo. (...) $O$ $\hat{E x o d o s ~ m e i o ~ q u e ~ a c o r d a ~ a ~ g e n t e . ~(J U ́ L I A ~ O U R I Q U E S, ~ a l u n a ~ d o ~} 3^{\circ}$ ano, Setor Leste - Brasília, DF, 10h30min).

A minha mãe nasceu aqui e eu também, então a gente sempre visitou várias cidades satélites. Então com o Êxodos, veio muito a contribuir com isso. Mas um lugar que eu não conhecia era o Plano eu não conhecia Asa Sul nem Asa Norte, aí por um acaso eu vim morar aqui. E assim, eu vejo Asa Sul e Asa Norte como algo muito estático. As coisas são sempre as mesmas por aqui (...) a única coisa que eu observo e acho muito impactante é o trânsito. Quando eu vou atravessar a L2 eu tenho medo de ser atropelada, por que eu paro pra ficar pensando no meio da L2. Eu penso: - Hoje é que dia? Hoje é sexta! Esse movimento 'tá' errado, 'tá' tendo alguma coisa de estranho por que era pra ter mais carros. Então com o Exxodos eu passei a observar pequenos detalhes que faziam parte do meu cotidiano, mas que passava batido. (...) Você acaba por pensar em pequenas coisas. (...) Você começa a interagir com o meio ambiente. (...) Você se sente parte disso tudo! (...) O $\hat{E} x o d o s$ é incrível por que ele te propicia essas coisas, você se sente importante no meio de tudo! (BÁRBARA COSTA, aluna do $3^{\circ}$ ano, Setor Leste - Brasília, DF, 10h30min).

Uma das coisas que me interessou na arquitetura foi o urbanismo, por que o curso é Arquitetura e Urbanismo. Então, as cidades, elas não existem só pra gente morar. Elas existem pra gente viver nelas. As cidades têm que ser construídas, criadas pra gente poder aproveitar elas como um todo. Então por que não tem mais banquinho pra gente sentar nas entrequadras? Por que os parquinhos das crianças estão "súper” precários? Enfim, 'n' questões assim. Por que os jovens de hoje em dia se entretém com coisas que eles não deviam? O que impede os jovens de aproveitarem as cidades deles de 
maneira ativa? Uma das coisas que acontecem é que as cidades não estão planejadas pra gente aproveitar elas. Estão planejadas só pra gente viver e fazer as coisas dentro de casa. E isso é uma coisa que o Êxodos ajuda a gente a ver e a questionar. Ante gente tem que viver na nossa cidade, a gente tem que aproveitar as coisas que ela oferece, a cidade tem que 'tá' oferecendo coisas pra gente. A gente tem que exigir isso da cidade, do nosso Governo e a gente tem que exigir isso de nós mesmos e das pessoas que estão a nossa volta. (JÚLIA OURIQUES, aluna do $3^{\circ}$ ano, Setor Leste - Brasília, DF, 10h30min)

É! Por que é até fácil criticar outras pessoas quando você não cuida, você sai destruindo as coisas assim como se elas não fizessem parte de você. Então o Exxodos mudou muito a minha visão disso: - Por que eu vou cuidar disso se não é meu? Mas é meu! Faz parte de mim, então eu tenho que cuidar. (...) Muda muito a sua visão do mundo. (BÁRBARA COSTA, aluna do $3^{\circ}$ ano, Setor Leste - Brasília, DF, 10h30min).

Casando os depoimentos mencionados com a posição de Bauman quanto ao que poderia ser feito para driblar a segregação a qual se tornou a sociedade moderna, ao final do capítulo de "Confiança e medo na cidade" o autor elucida:

Seria mais favorável à proteção e ao cultivo de sentimentos mixófilos - no planejamento arquitetônico e urbano - a estratégia oposta: difusão de espaços públicos abertos, convidativos, acolhedores, que todo tipo de cidadão teria vontade de frequentar assiduamente e compartilhar voluntariamente e de bom grado.

Como disse muito bem Hans Gadamer - em Verdade e método -, a compreensão recíproca é obtida com uma "fusão de horizontes"; horizontes cognitivos que são traçados e ampliados acumulando-se experiências de vida. A fusão que uma compreensão recíproca exige só poderá resultar de uma experiência compartilhada, e certamente não se pode pensar em compartilhar uma experiência sem partilhar um espaço. (BAUMAN, 2009, p.21).

Compartilhar experiências é algo que os coordenadores do Projeto $\operatorname{Re}(v i) v e n d o$ Êxodos trabalham muito bem com os jovens participantes. Em sequência, imagens representativas de duas das vivências compartilhadas pelos alunos: 


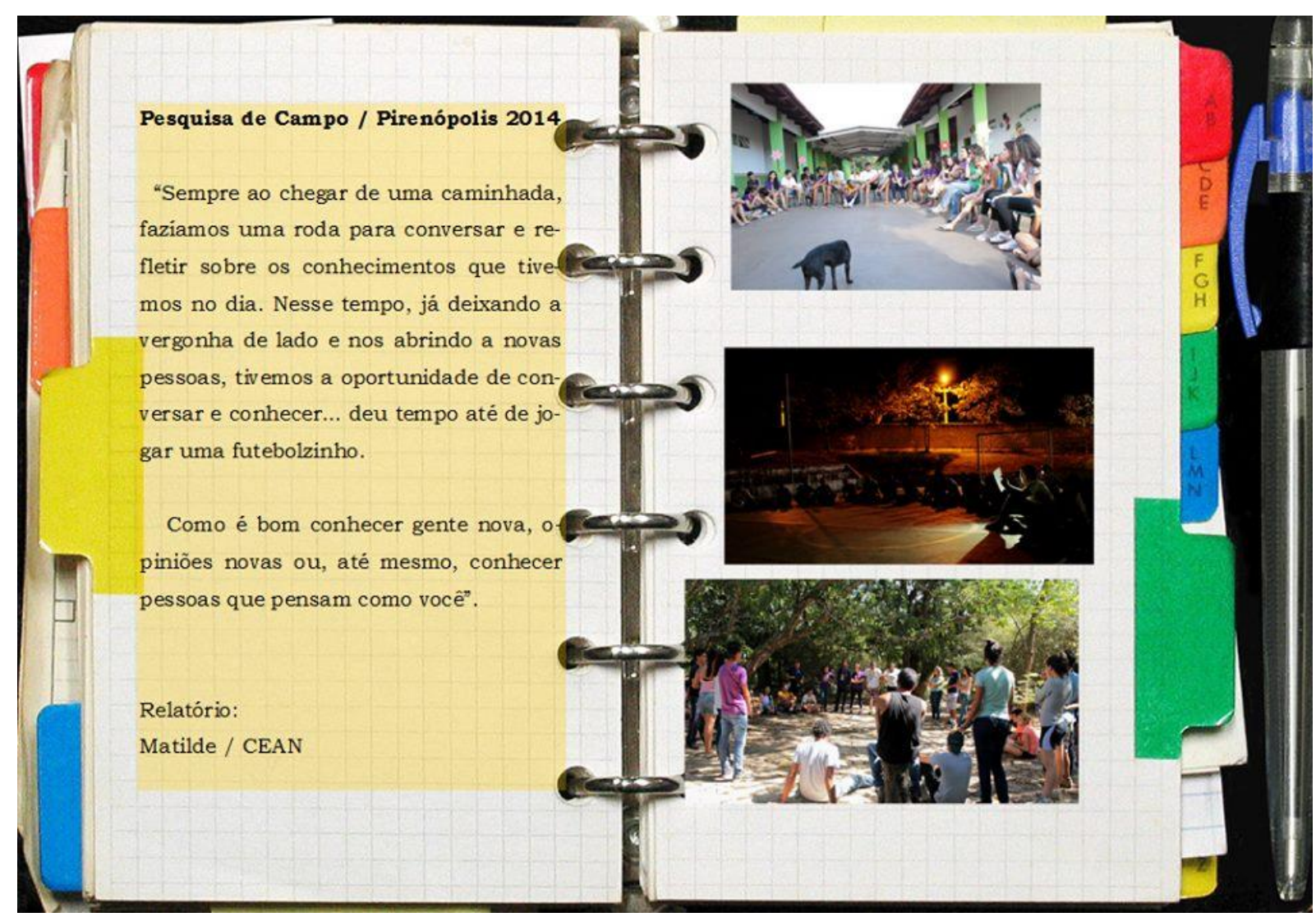

Figura 4: Relato da aluna Matilde do Centro de Ensino Médio da Asa Norte sobre pesquisa de campo feita em Pirenópolis - GO pelo Projeto Re(vi)vendo Êxodos no ano de 2014.

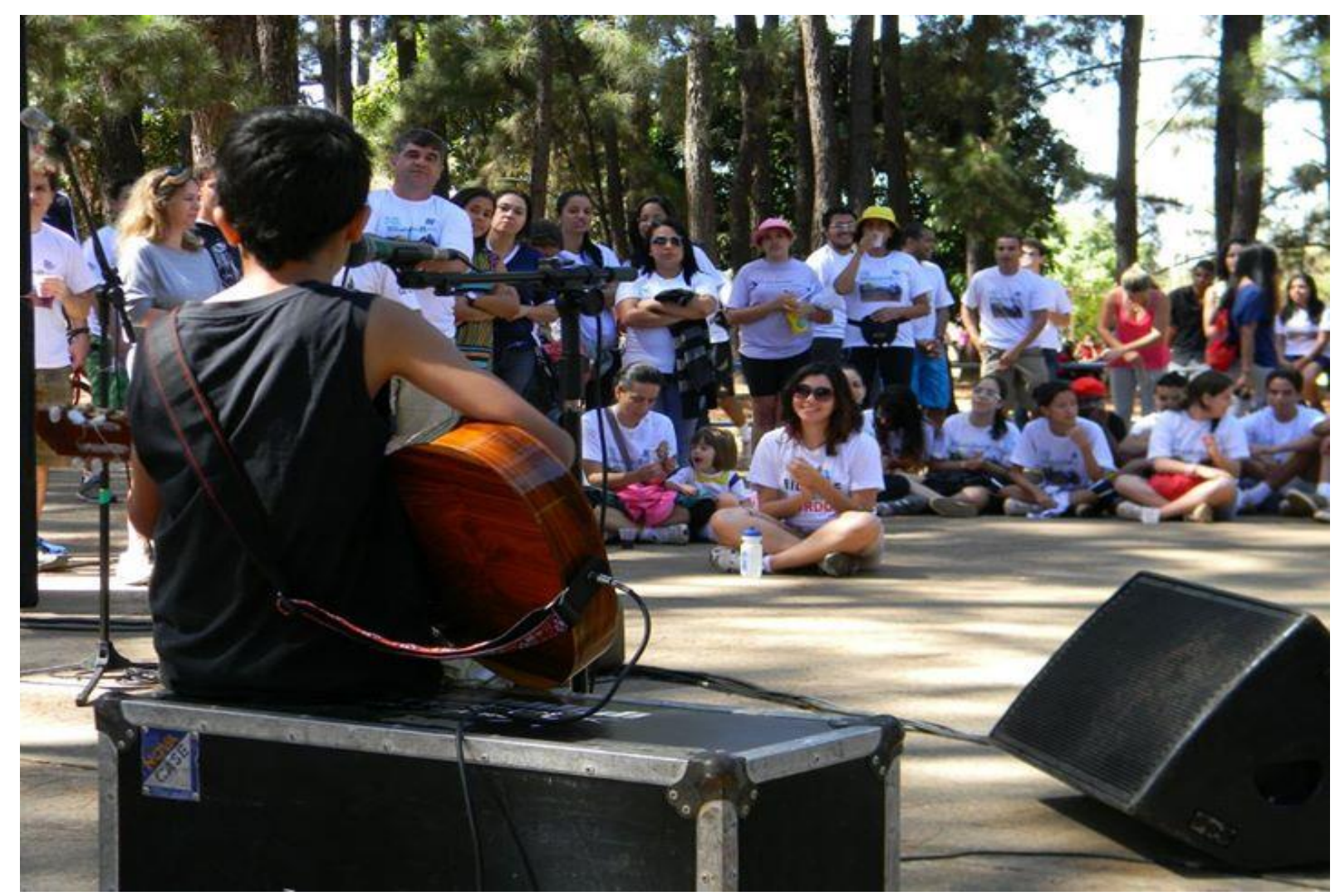

Figura 5: Sarau - Comemoração dos 11 anos do Projeto Re(vi)vendo Êxodos, 2012. 


\section{3 - Re(vi)vendo a Educação Patrimonial}

Considerando que a cultura é Patrimônio, que, de acordo com Thompson, a experiência compartilhada pelos sujeitos históricos é responsável pelas mudanças sociais e culturais, logo, por uma análise silogística: experiência é Patrimônio. Não só por isso. Sendo Patrimônio uma questão de pertencimento, nada pertence mais ao indivíduo, ou ainda, aos indivíduos do que suas experiências singulares ou compartilhadas. Maior significado, ainda, possuem aquelas experiências que estão associadas a outros Patrimônios.

Esta ideia inicial foi incitada pelos depoimentos dos alunos do Projeto $\operatorname{Re}($ vi)vendo Êxodos quanto à noção que têm sobre o Patrimônio:

Patrimônio é muito legal! Boa parte dos lugares que a gente foi eu nunca tinha ido aqui em Brasília. Fui na Candangolândia, no museu da Caixa, museu do Banco do Brasil, vários lugares que eu nunca tinha ido. (FRANCISCO VLADIMIR, aluno do $2^{\circ}$ ano, Setor Leste - Brasília, DF, 21 de outubro de 2014, 09h30min).

O meu grupo foi pra Ceilândia, então tinham vários lugares lá, tipo a Casa do Cantador. Nossa! Muito show! Também fomos na área militar. A gente acaba descobrindo muitas coisas históricas que ninguém conhece. A gente sempre fica almejando ir pros outros lugares e acaba não conhecendo o nosso próprio. (HÉRISSON DUARTE, aluno do $2^{\circ}$ ano, Setor Leste Brasília - DF, 21 de outubro de 2014, 09h30min).

É! Aprende sobre a história de Brasília né? Por que como Brasília é uma cidade muito jovem, você andando nas ruas não vê a história da cidade, você não vê monumentos antigos e tal, por que você vê, por exemplo, o museu, o congresso são coisas muito recentes, parece que foi feito ontem, não têm noção ainda do valor histórico que têm. Aí a gente vai fazendo essas visitas nas outras cidades e vê que o tempo passa né? Tipo na Candangolândia é uma cidade que... na verdade era um acampamento pra auxiliar na construção de Brasília e hoje já é uma cidade fixa, já têm gerações ali. (FRANCISCO VLADIMIR, aluno do $2^{\circ}$ ano, Setor Leste - Brasília, DF, 21 de outubro de 2014, 09h30min).

Ao falar do significado de Patrimônio Hérisson e Francisco Vladimir contam sobre suas experiências ao conhecerem lugares do Distrito Federal que, até então, não tinham conhecimento. O que se destaca nestes relatos é o fato de que os locais visitados por Hérisson e Francisco, mesmo os dois sendo moradores do Distrito Federal, só lhes 
remeteram ao significado de Patrimônio a partir do momento em que tiveram contato eles, ou seja, a partir das experiências vividas em relação a estes locais.

Estes depoimentos são a representação da vivência dos jovens participantes do Re(vi)vendo Êxodos, porém, mais do que isso, são a representação explícita do que é a Educação Patrimonial. Uma instigação, um impulso ao indivíduo para que conheça o resultado das experiências compartilhadas por outros sujeitos históricos e, desta forma, possa fazer parte delas por meio de suas próprias experiências.

As alunas do $3^{\circ}$ ano expuseram as seguintes opiniões:

O Patrimônio é quem você é! Não tem outra explicação. Pra mim não tem. $O$ Patrimônio é quem você é e o que te pertence. Não questões, assim, materiais. (...) É aquilo que te pertence e você reconhece como seu, e você cuida, você zela, você respeita aquilo. Sabe? Como algo que te pertence, como algo que é parte de você. (BÁRBARA COSTA, aluna do $3^{\circ}$ ano, Setor Leste - Brasília, DF, 10h30min).

Bárbara especifica a questão do reconhecimento que, também, é posterior à experiência. Primeiro se tem o contato com o desconhecido, onde se inicia a experiência, posteriormente se reconhece aquilo que se conheceu.

Júlia esclarece que:

Uma das coisas que a gente aprendeu com o texodos foi isso. Não só aprendeu, mas aprendeu a valorizar. É o patrimônio imaterial. Por que a gente acha que as outras religiões, que não são majoritárias no Brasil, não são importantes? Elas são importantes. Enfim, todas as coisas. A natureza, o meio ambiente, o cerrado, tudo isso é muito importante. Tudo isso é patrimônio que a gente tem que aprender a cuidar. (JÚLIA OURIQUES, aluna do $3^{\circ}$ ano, Setor Leste - Brasília, DF, 10h30min).

Júlia relata a questão de: primeiramente, aprender sobre e Patrimônio e, em seguida, aprender a valorizá-lo. Esta questão remete algo que é importante destacar. Ao tratar da experiência vivida como representação do patrimônio inclui-se, não apenas a experiência prática, mas também, a experiência da teoria compartilhada. Uma vez que, parafraseando Dewey, a experiência é provida de ciência e de razão. 
Considerando-se que a formação da identidade não se dá de forma individual, mas sim agregada a outros indivíduos por meio da troca de experiências, uma vez que, “não somente cada parte está no todo como o todo está também em cada parte; o indivíduo, na sociedade, mas também a sociedade enquanto todo, no indivíduo" (PENA-VEGA, 2003, p. 150), compreende-se que o Patrimônio Cultural possui grande influência na construção da identidade de um indivíduo ou grupo social, uma vez que este carrega símbolos e significados que são representações da cultura de determinada comunidade ou sociedade. O Patrimônio cultural é resultado das interações e práticas sociais. Por este motivo, sua preservação é de suma importância.

Há que se destacar a existência da identidade coletiva e da identidade individual. Tanto uma quanto a outra são construídas por meio da experiência compartilhada, podendo ter influência de diferentes culturas. O Patrimônio Cultural é "objeto" de representação destas culturas.

A Educação Patrimonial trabalhada pelo Re(vi)vendo Êxodos é a união entre o estímulo teórico em sala de aula e a experiência da prática vivida pelos alunos ao conhecerem lugares, monumentos, manifestações culturais e outros bens materiais e imateriais que passam a sentir que os pertence por fazerem parte da história do lugar onde vivem ou que passam a valorizar por conhecerem a história dos sujeitos a quem estes bens pertencem. O Re(vi)vendo Êxodos é capaz de transmitir aos alunos a importância que o Patrimônio Cultural possui na construção de suas identidades, auxiliando-os a se descobrirem como sujeitos atuantes no espaço que ocupam e, em consequência, integrantes do processo de ressignificação da cultura.

A experiência, de acordo com Dewey (1967), faz parte do processo de aquisição de conhecimento, sendo assim, a experiência na Educação Patrimonial, mediante a interação vivida pelo indivíduo com o meio social, permite que esse adquira novos conhecimentos referentes às práticas e conceitos culturais de uma sociedade. A ressignificação da cultura ocorre neste sentido, uma vez que a aquisição de novas experiências não exclui experiências passadas, o processo do conhecimento com base na experiência se dá de maneira progressiva, quanto mais experiências o indivíduo adquire, maior será a possibilidade de combinar elementos destas experiências e, 
consequentemente, ressignificá-los, do mesmo modo que, quanto maior e mais complexo for o ambiente de interação social, ou seja, quanto maior for a heterogeneidade cultural dos indivíduos que compartilham experiências, maior será a possibilidade de combinações e ressignificações culturais.

Esta possibilidade de ressignificação permite, ainda, que não apenas as experiências mudem, mas que a própria interpretação sobre uma mesma experiência se altere mediante a vivência de novas experiências que permitirão o redimensionamento do olhar. Sendo assim, uma mesma experiência pode representar coisas distintas em momentos distintos da vida de um indivíduo. Assim como, uma mesma representação cultural pode significar coisas diferentes em momentos diversos.

Ainda, sobre o redimensionamento do olhar:

Nas cidades, sob movimentos constantes, a percepção do tempo e do lugar no contexto da vida contemporânea exige redimensionamento. $\mathrm{O}$ olhar sobre o cotidiano - mais precisamente, o olhar, como resultado das experiências e sensações experimentadas sob a influência do efêmero e da imaterialidade, passa a ocupar um lugar essencial na construção da percepção da cidade. Sob constantes deslocamentos, a percepção do tempo e do lugar requer redimensionamento. (LENZI, 2014)

Por este motivo é tão importante a questão da Educação Patrimonial, ela direciona o indivíduo na busca do que é essencial na cultura local, na busca dos fatores que representam a cultura e que poderão auxiliar na construção da identidade. A Educação Patrimonial tem, ainda, o papel de orientar quanto à importância de se preservar o Patrimônio local para que, por exemplo, a arquitetura da cidade não se torne uma construção representada por imagens e símbolos, ou seja, a simulação da construção, quando, ao contrário, deveria ser uma representação construída. (PEIXOTO, In NOVAES, 1988).

Desta forma, o redimensionamento do olhar a partir das novas experiências do indivíduo na cidade possibilitará a mudança da percepção em relação à própria cidade e tudo o que a compõe como, por exemplo, o Patrimônio Cultural.

Finalizando seu relato sobre o que considera ser Patrimônio, Júlia explica: 
Parte de ser cidadão, de agir como cidadão é você saber cuidar do seu patrimônio, tanto material quanto imaterial. (JÚLIA OURIQUES, aluna do $3^{\circ}$ ano, Setor Leste - Brasília, DF, 10h30min).

Com esta fala, Júlia dá início à outra discussão que, também, é profundamente considerada e trabalhada no Projeto Re(vi)vendo Êxodos: a cidadania.

\section{4 - Re(vi)vendo a Cidadania}

Considerando que a cidadania pressupõe a consciência do sujeito quanto às injustiças existentes, os direitos e deveres que possui, às tentativas de mudança dos rumos da história mediante a participação ativa dos membros da sociedade, admite-se que "cidadão é o homem participante" (Martins, 2003, p. 14)

O Re(vi)vendo Êxodos é responsável pela formação de jovens conscientes quanto ao seu papel como habitante da cidade e do mundo. O projeto possui diversas atividades voltadas para pesquisas de campo no Distrito Federal e entorno. Durante estas pesquisas os jovens conhecem e aprendem sobre as histórias de outras cidades e seus habitantes. Além de conhecer culturas diferentes, os jovens passam por aprendizados quanto às diferentes realidades sociais em uma mesma região ou cidade o que lhes ensina que cidadãos que não se envolvem coletivamente com o local onde vivem podem sofrer muitas consequências pela inércia. Contudo, aprendem, também, que sujeitos organizados e atentos tendem a obter conquistas benéficas para sua comunidade.

A Educação Patrimonial praticada pelo projeto Re(vi)vendo Êxodos focaliza as questões de cidadania, destacando o papel que deve ser desempenhado pelos alunos na cidade em que vivem e, também, nas cidades que visitam.

O monitor Rafael, ao relatar sobre sua mudança pessoal desde que entrou no Re(vi)vendo Êxodos, narra algumas de suas experiências mais marcantes pelo projeto e menciona uma atitude do professor Luís Guilherme que exemplifica nitidamente a forma como a questão da cidadania é defendida e cobrada pelo $\operatorname{Re}(v i) v e n d o$ Exxodos. Rafael explana: 
Eu reconheço bastante o momento de mudança como pessoa... Não sei... O modo de ver o mundo mesmo. Eu acho que a sensibilidade é o que o Exxodos proporcionou. Teve um grande impacto pra mim. Não só no curso, na opção de escolha do curso ${ }^{9}$, mas na forma da gente lidar com as pessoas mesmo. (...) E mais que isso, nas relações humanas: "Nós chegamos pra comer na Secretaria de Obras e ninguém tratou com bom dia, boa tarde... Educação mínima! Daí depois o Luís Guilherme pagou um sapo geral pra turma... Que quando a gente chegou, a gente não falou com o Seu Baiano que tava ali todo quieto na dele, feliz de ver a galera chegando, mas ninguém cumprimentou ele, nem conversou. Depois todo mundo com a pança cheia, comida deliciosa, aí ele (o Professor Luís Guilherme) pagou um sapo, chamou as cozinheiras, como ele faz normalmente, pra agradecê-las... Entendeu? Algumas coisas óbvias assim, mas que os alunos às vezes precisam... O óbvio às vezes precisa ser dito né? A gente começou a conversar e as cozinheiras se sentiram importantes, entendeu? Entrevistando as cozinheiras, entrevistando ele (O Senhor Baiano), ele se emociona... As pessoas se emocionam também. Então, acho que... Me marcou bastante essa pesquisa de campo. Assim como no outro dia, no domingo... Foi lá no Mesquita, uma região quilombola na Cidade Ocidental, as pessoas se lembrando né... Uma senhora tinha cento e vinte anos de idade, por exemplo, lembrando do irmão, quando era criança... Impactou bastante, emocionou a todos. Todos se emocionaram nesse dia! (...) Então eu acho que... Pelo $\hat{E} x o d o s$ ele acabava, ainda mais, abrindo esse horizonte de expectativas né... Essa perspectiva, um olhar diferenciado. (...) Teve um 'toquinho' do Exxodos no olhar que eu tenho hoje entendeu? Das relações da sociedade, das pessoas... Com certeza eu aprendi bastante com o Êxodos! (RAFAEL GOMES, Monitor do Re(vi)vendo Êxodos, UnB - Brasília, DF, 04 de novembro de 2014, 15:00h).

A fala de Rafael demonstra a preocupação do Professor Luís Guilherme em ensinar aos alunos a se relacionarem de forma respeitosa e cidadã com as pessoas que vivem ou trabalham nos lugares que visitam. O relato anterior evidencia, ainda, que ao mesmo tempo em que ensina aos alunos a serem indivíduos responsáveis pelo seu papel como cidadãos nas cidades que habitam o Re(vi)vendo Êxodos educa estes jovens a serem turistas conscientizados do seu papel como cidadãos nas cidades que visitam. Isto, por que, a Educação Patrimonial tem a importante capacidade de fazer com que os indivíduos que nela são envolvidos apreciem e se interessem por diferentes formas de viver, diferentes culturas e diferentes pessoas a partir das experiências compartilhadas, reconhecendo como Patrimônio, não só o que lhes pertence, mas, inclusive, o que pertence ao outro.

Os alunos dos $2^{\circ}$ e $3^{\circ}$ anos do Ensino Médio foram questionados quanto ao que compreendiam por cidadania e, como comprovação de que as atividades propostas pelo

\footnotetext{
${ }^{9}$ Rafael se refere à sua graduação em História.
} 
Re(vi)vendo Êxodos envolvem de maneira profunda esta questão, os estudantes esboçaram com convicção suas opiniões acerca do tema:

Cidadania sempre me lembra de qualidade de vida, onde a gente mora. No $\hat{E} x o d o s$ a gente sempre acaba vendo a condição de outras pessoas. Aí a gente fica: - 'Caraca', a minha nem é tão ruim assim! Ou então: - 'Caraca', a minha pode melhorar! (HÉRISSON DUARTE, aluno do $2^{\circ}$ ano, Setor Leste - Brasília - DF, 21 de outubro de 2014, 09h30min).

Cidadania é o princípio básico que a gente tem hoje, se colocar no lugar do outro. Aí quando a gente vai nas outras cidades a gente vê que ali têm problemas que não tem na nossa, ou coisas que são melhores e que na nossa não tem. E aí a gente vê que na verdade a gente só precisa tá junto pra conseguir aquilo tudo, vê que isso é possível. (FRANCISCO VLADIMIR, aluno do $2^{\circ}$ ano, Setor Leste - Brasília, DF, 21 de outubro de 2014, 09h30min).

Sério! Pra mim! Pode ser o conceito mais errôneo do universo, mas quando se fala em cidadania eu sempre penso na questão coletiva. Como as pessoas tratam umas as outras e como elas são por dentro. Muitas pessoas são vazias por dentro, não sabem nem o que estão fazendo aqui, mas estão sobrevivendo. Então, quando fala em cidadania eu penso nessa questão de como a gente vive um do lado do outro. Cidadania é como você se encontra no meio de todo mundo e como você se relaciona com as pessoas. (BÁRBARA COSTA, aluna do $3^{\circ}$ ano, Setor Leste - Brasília, DF, 10h30min).

Eu acho que em termos mais filosóficos, mais artísticos, é a arte de viver em sociedade. Viver! Não só sobreviver, não ser mais um grão de arei na praia, mas você ser um membro da sociedade, você ser um membro ativo, você ser um membro crítico, você ser um agente de mudança, você ser uma pessoa, assim, em termos burocráticos, que sabe seu direitos, que sabe seus deveres, que sabe como lidar com tudo isso e você ter uma atitude de mudança quanto ao meio em que você está vivendo. (JÚLIA OURIQUES, aluna do $3^{\circ}$ ano, Setor Leste - Brasília, DF, 10h30min).

Verifica-se na fala dos alunos do $2^{\circ}$ ano a referência das experiências vividas no Projeto Re(vi)vendo Êxodos como exemplos do que entendem por cidadania. Percebese que a partir das vivências é que eles elaboraram o conceito de cidadania. Os quatro estudantes não reproduziram um conceito ideal aprendido teoricamente em sala de aula, e sim elaboraram um conceito factual embasado em suas próprias experiências. Cabe aqui relembrar a posição de Merleau Ponty quanto à experiência, ao enxerga-la como o caminho que leva em direção ao ambiente físico e social: 
Tudo aquilo que sei do mundo, mesmo por ciência, eu o sei a partir de uma visão minha ou de uma experiência do mundo sem a qual os símbolos da ciência não poderiam dizer nada. (PONTY, 1994, p. 3)

Compreende-se, desta forma, que a cidadania é, também, apreendida por meio das experiências vivenciadas pelo sujeito tanto em seu local de residência quanto em outros espaços. Para Gastal:

A cidadania, se associada ao turismo, encaminharia outras possibilidades de construção do sujeito histórico, em condições de expressar-se e se apropriar das suas circunstâncias, seja como sujeito histórico urbano, seja como sujeito histórico planetário. (GASTAL, 2006, p.9).

Ao fazer esta relação entre cidadania e turismo, Gastal propõe dois conceitos diferenciados. O primeiro o Cidadão Turista e o segundo o Turista Cidadão:

\begin{abstract}
As pessoas, moradoras ou usuárias das cidades, não são fixos, mas fluxos a percorrer estes espaços. Colocar os moradores das cidades em movimento assumindo sua condição de fluxos - para além de suas práticas rotineiras, num primeiro momento pode transformá-lo no cidadão turista, que irá, com o deslocamento, apropriar-se com maior competência dos espaços e situações. A cidade nos seus fixos, deixa de ser uma desconhecida, mesmo para seus próprios moradores, e torna-se o território familiar ao qual se constrói pertencimento e identificação, por passar a compartilhar seus códigos e, com eles, situar a própria subjetividade no urbano. Por outro lado, falar em turista cidadão seria avançar no conceito, e supor o sujeito formado e politicamente atuante nestas práticas. O sujeito que entendeu os fixos, precisa apropriar-se dos fluxos, neles compreendidos a sua própria situação de sujeito em trânsito, para nela colocar subjetividade, aprendendo a expressá-la na mundo, como proposto por Manzini-Covre. (GASTAL, 2006, p. 9) (Grifo do autor).
\end{abstract}

Entende-se assim, que a prática do turismo cidadão permite que o sujeito assuma-se como turista mesmo na cidade em que habita o que torna possível vivenciar as experiências que o turismo oferece sem, necessariamente, se deslocar por grandes distâncias. Gastal afirma ainda:

[...] para viver outros cenários, não seria mais necessário sair dos limites da cidade, pois esta se tornou o território da multiplicidade, permitindo sermos turistas mesmo sem abandonar seu território. Também se estaria migrando de um conceito de turismo marcado pelas distâncias espaciais, para um conceito que priorizaria a sua prática como o percorrer tempos e espaço diferente dos rotineiros. Turismo seria menos o percurso no espaço, para tornar-se um percurso por tempos-espaços, em especial culturais, diferentes daqueles a que se esteja habituado, com ênfase nas vivências e experiências. (GASTAL, 2006, p. 8) 
Com base nos diversos relatos analisados, nota-se que o Projeto $\operatorname{Re}(v i) v e n d o$ Êxodos, por meio do ensino teórico transdisciplinar entre as aulas convencionais e a Educação Patrimonial complementadas com as experiências compartilhadas fora de sala de aula estimula os jovens a terem um olhar diferenciado em relação à sua cidade, aos novos lugares e diferentes pessoas que conhecem, ao mundo e à eles mesmos como indivíduos responsáveis que interferem no meio, tornando-os Cidadãos Turistas, e que ao se colocarem em trânsito atuantes no mundo tornam-se Turistas Cidadãos.

\section{5 - A Formação do Turista Cidadão}

É importante mencionar que a concepção que se trabalha nesta dissertação acerca do Turista Cidadão não é uma proposta de se definir uma tipologia de Turista separando-o dos demais indivíduos que praticam o turismo, uma vez que se procura, ao máximo, o distanciamento do pensamento dicotômico. E ainda, que o entendimento que se atribui ao conceito de Turista Cidadão não se restringe aos sujeitos que se afastam simbolicamente do cotidiano sem se afastar literalmente do local onde habitam. O Turista Cidadão é o sujeito que, a partir desta percepção apreendida em sua própria cidade, se apropria dos espaços de forma cidadã exercitando o olhar não se restringindo à distância e período de tempo específicos.

O Turista Cidadão é aquele que passa por um processo de adaptação do olhar e de reconhecimento de sua cidade como um espaço além da utilidade de residência e que, ao mesmo tempo, apreende a cidadania em suas práticas.

Após análise do $\operatorname{Re}($ vi)vendo Êxodos, pode-se compreender que, de fato, o Projeto oferece, por meio da Educação Patrimonial, uma formação complementar que possibilita o redirecionamento do olhar do estudante fazendo com que este compreenda a importância de práticas cidadãs, como a preservação patrimonial, por exemplo, incentivando a descoberta e reconhecimento da identidade de cada jovem por meio da apreciação da cultura, dos símbolos e signos que estão relacionados a este patrimônio e, ainda, a descoberta de sua cidade de residência como um local passível de apropriação 
para o uso além de habitá-lo, mas, também, um local de aproveitamento de espaços públicos para o estranhamento e entretenimento.

Esta análise do Re(vi)vendo Êxodos permitiu identificar, também, com base nas entrevistas, o processo de amadurecimento dos jovens durante as fases em que participam do Projeto: segundo e terceiro anos do Ensino Médio e monitoria. Vale ressaltar que, com o intuito de evitar que a participação na monitoria restrinja a vida profissional e acadêmica do monitor, há uma exigência de que o jovem tenha ingressado em uma universidade ou faculdade antes de fazer parte disto, sendo assim, todos os monitores entrevistados são universitários ou graduados o que influencia também nesta

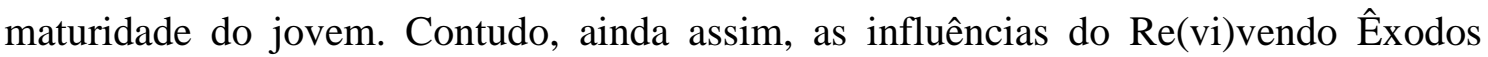
estão visivelmente presentes nos relatos destes entrevistados.

Esta diferença de nível de apreensão da formação complementar que o Re(vi)vendo Êxodos oferece, ou seja, os níveis de profundidade da constituição do Turista Cidadão em que se encontra cada jovem fica mais nítida em alguns relatos. Foi questionado, por exemplo, aos alunos do $2^{\circ}$ ano se eles caminhavam por dentro da cidade com a intenção de apenas observá-la.

Francisco Explica que fazem isso ao colocar em prática as atividades do projeto, pois o projeto não é só a pesquisa de campo, mas são vários tópicos dentro da própria cidade. Desta forma, precisam ir a exposições e visitar monumentos, por exemplo, e neste momento eles praticam este exercício de observação

\footnotetext{
A gente faz essa busca né? Quando a gente vai... Por que no Projeto não é só a pesquisa de campo né? A gente tem que estudar exposições, tem que procurar monumentos, pesquisar artistas e tal, e aí tudo isso a gente vai... É... A cidade quase como uma única coisa que tem vários tópicos né? Como a árvore que tem vários galhos, aí a gente vai vendo né? Vai fazendo uma atividade e vai pesquisando sobre artistas (...). (FRANCISCO VLADIMIR, aluno do $2^{\circ}$ ano, Setor Leste - Brasília, DF, 21 de outubro de 2014, 09h30min).
}

Neste momento, os alunos foram questionados quanto às fotografias, uma vez que, ao final de cada ano letivo é feita uma exposição com as imagens fotografadas pelos alunos durante o ano. Foram questionados, então, se estas imagens eram feitas durante estas saídas de campo. Hérisson esclarece quanto às fotografias e explica, ainda, 
que quando eles vão realizar as pesquisas de campo no Re(vi)vendo Êxodos eles recebem alguns temas de investigação e para conseguir chegar nos pontos onde vão encontrar a representação destes temas, eles montam uma rota e, assim, dentro dessa rota, vão passando por outras localidades que não estão propriamente inseridas no tema porém, neste momento, aproveitam para olhar estes lugares novos:

\begin{abstract}
Acaba tendo mais valor quando a gente tira fotografia... Não é obrigado desde o primeiro bimestre entendeu? Mas chega um bimestre que ele (Professor Luís Guilherme) cobra. Então, se desde o primeiro a gente já vai tirando ele fala: "Ó ficou legal isso aqui e tal... Você tem uma facilidade...". Acaba instigando a gente a procurar e continuar. Que nem quando a gente visita uma cidade... Não que aqui, a gente saia do colégio: "Não... Vamos visitar Brasília!". Não! Agora quando a gente sai para o Êxodos, a gente escolheu uma cidade, então a gente tem que procurar três tópicos... Quatro ou três tópicos, se eu não me engano. A gente tem que ir em tais monumentos, tais lugares. Então a gente vai ter que fazer uma rota, a gente acaba vendo outras coisas nessa rota entendeu? (HÉRISSON DUARTE, aluno do $2^{\circ}$ ano, Setor Leste - Brasília - DF, 21 de outubro de 2014, 09h30min).
\end{abstract}

Os relatos acima mencionados mostram como funciona a prática das atividades de pesquisa do Projeto Re(vi)vendo Êxodos. Compreende-se com base nestas declarações que estas atividades influenciam, em muito, na formação do perfil do Turista Cidadão, uma vez que a partir delas os jovens são, como Hérisson esclarece, instigados a buscar pelo desconhecido na cidade que, aparentemente conhecem.

Gastal, no livro "Turismo, Imagens e Imaginário" trabalha com uma breve conceituação de Turismo que aqui se faz apropriada:

[...] no contexto deste livro, falar em turismo significará fazer referência àquelas pessoas que saem das suas rotinas espaciais e temporais por um período de tempo determinado: o cidadão que sai em férias, os netos que visitam os avós, o executivo que viaja a negócios, mas não regularmente, para o mesmo destino. Ou seja, mesmo aquelas pessoas que, morando numa grande cidade, num determinado bairro, aproveitam o fim de semana para buscar outros espaços nessa mesma cidade - um parque, uma praia, um grande evento acontecendo num centro de convenções, uma festa de devoção religiosa... -, essas também serão consideradas turistas. (GASTAL, 2005, p. 12). (Grifo da autora).

A partir deste conceito a autora explica, ainda, o que há em comum entre um deslocamento para além das fronteiras nacionais e um deslocamento para além das fronteiras do bairro de residência: "Diria que, em comum aos dois, há o estranhamento, 
o prazer e uma certa ansiedade diante do desconhecido e do novo." (GASTAL, 2005, p. 12).

Com base nestes conceitos, explicita-se, que a experiência turística, para ser vivida, não exige grandes deslocamentos. $\mathrm{O}$ sujeito tem possibilidades de vivenciar o fenômeno turístico nas proximidades de sua própria cidade, desde que saia da rotina habitual por meio da busca pelo desconhecido, por viver novas experiências.

Os relatos de Hérisson e Francisco mostram exatamente o contentamento que sentem ao se deparar com o desconhecido e novo. Mostra que fora dos limites do Distrito Federal, ou dentro destes limites, é possível viver a experiência turística.

Percebe-se, contudo, com as informações passadas pelos estudantes do $2^{\circ}$ ano que quando questionados sobre os temas trabalhados pelo Projeto, suas experiências ainda estão mais restritas às atividades realizadas junto ao $\operatorname{Re}(v i) v e n d o$ Êxodos. Sendo assim, entende-se que estão em fase inicial do processo de formação do Turista Cidadão. No entanto, ao questionar o que o Re(vi)vendo Êxodos representava pra eles, os estudantes responderam:

Conhecer a si mesmo. (HÉRISSON DUARTE, aluno do $2^{\circ}$ ano, Setor Leste Brasília - DF, 21 de outubro de 2014, 09h30min).

Buscar a si mesmo, buscar a sua própria essência. (FRANCISCO VLADIMIR, aluno do $2^{\circ}$ ano, Setor Leste - Brasília, DF, 21 de outubro de 2014, 09h30min).

Nota-se com estas falas que os alunos compreendem o papel do $\operatorname{Re}($ vi)vendo Êxodos na concepção da própria identidade por parte de cada estudante. Além disso, no momento em que relatavam qual o maior aprendizado que tiraram do Projeto, após explanarem sobre as questões de "sair da zona de conforto", já citadas anteriormente, Hérisson complementou dizendo:

É! Assim... (...) Todos almejam conhecer São Paulo, Rio de Janeiro, por que lá tem praia, mas... E o nosso lugar? Entendeu? Aqui em Brasília... Tem o lago, tem uma ilha no lago (Lago Paranoá), tem uma cidade na Praça dos Três Poderes subterrânea que ninguém conhece. Tem muita coisa que a gente não sabe, muita coisa que tá pra gente, tá entregue pra gente e a gente não foi atrás buscar conhecer a nossa própria história! (HÉRISSON 
DUARTE, aluno do $2^{\circ}$ ano, Setor Leste - Brasília - DF, 21 de outubro de 2014, 09h30min).

A fala de Hérisson mostra que, mesmo relacionando mais, a necessidade de

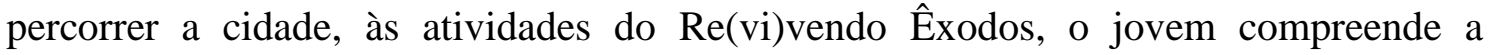
importância de conhecer a cidade onde mora para, ao mesmo tempo, conhecer sua história. Para Moesch,

\begin{abstract}
A experiência do turista cidadão, carregada de subjetividade, se expressa, porém, objetivamente nas vivências ocorridas durante o tempo de lazer, no consumo de práticas de entretenimento cultura e meio ambiente. Este processo ocorreria por meio do estranhamento da própria cidade, especialmente na percepção estética da paisagem urbana pelo habitante. (MOESCH, 2005, apud, SALES, 2006).
\end{abstract}

Hérisson cita como exemplos de atrativos que Brasília possui o Lago Paranoá e a Praça dos Três Poderes. Tanto um quanto outro são locais da cidade propícios às práticas de entretenimento, cultura e lazer. Hérisson fala, ainda, do fato de haverem moradores da localidade que não conhecem estes e outros locais de entretenimento que a cidade possui. O estudante é capaz de esclarecer isto por ter vivido, a partir do Re(vi)vendo Êxodos, esta experiência de desvendar o desconhecido dentro de sua própria cidade e se aproximar da cultura local.

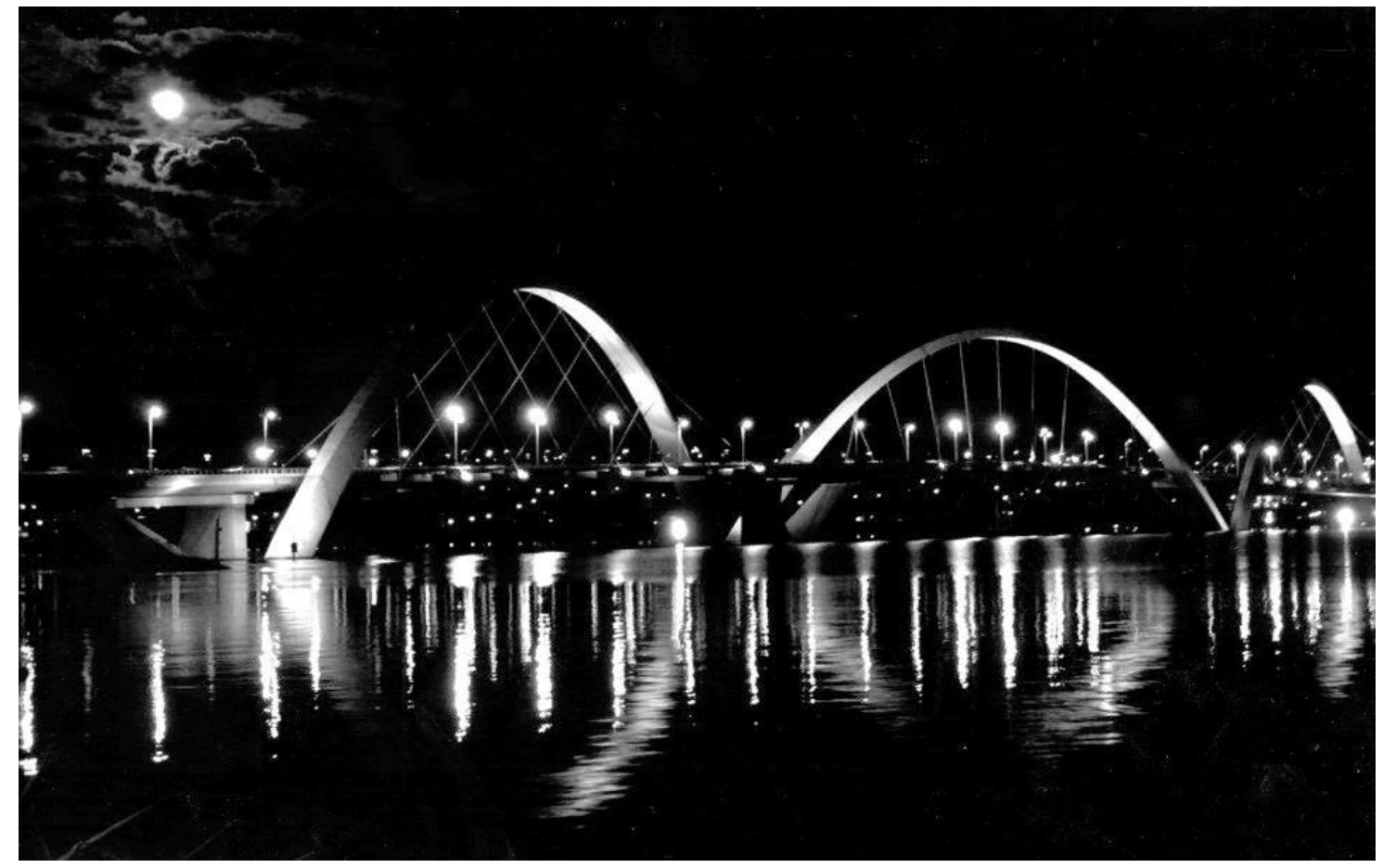

Figura 6: Vista noturna da Ponte JK - Lago Paranoá - Fotografia tirada por alunos do Re(vi)vendo Êxodos, 2013. 
Outro relato que possibilita a análise do nível de profundidade da formação dos participantes do $\operatorname{Re}(v i) v e n d o$ Exxodos se relaciona às respostas fornecidas pelos monitores Rafael e Pedro Victor ao serem questionados quanto a maneira de se relacionarem com a cidade em que vivem após a participação no Re(vi)vendo Êxodos.

Rafael esclarece que trabalha fora da cidade satélite onde mora, sendo assim, ainda existe essa relação de cidade "dormitória"10. Mas apesar de não ter muitas experiências na cidade onde reside, diferente de antes, hoje tem uma compreensão maior sobre o lugar onde mora, um olhar diferenciado, maior preocupação e vontade de se integrar mais àquele meio do que o permitido pela sua rotina de trabalho e estudos.

Eu, particularmente, continuo muito aqui pelo Plano né? Asa Sul e Asa Norte. Mas desde o projeto a gente passou a ver várias formas diferentes né? Ampliamos a nossa perspectiva, o nosso horizonte. Por um lado, eu acho que o reconhecimento é um dos primeiros pontos né? Sentir parte da cidade é uma das coisas (...). Sentir... fazer parte na verdade né? Pertencer a um determinado espaço. Acho que é muito importante. E Brasília no sentido plural né? Justamente agregando todas essas outras cidades. Mas por um lado, ainda hoje, eu conheço a cidade onde eu moro, ainda que não tenha uma experiência, uma vivência na cidade onde eu moro. Mas já pensei em desenvolver alguns projetos justamente próximos, a partir do Projeto Êxodos mesmo. Desenvolver algum trabalho voluntário, por exemplo, em alguma escola. Já conheço alguns projetos culturais, bem interessantes, que são aplicados lá na cidade onde eu moro, mas pela vida acadêmica e profissional, acaba que eu não tenho uma vivência lá, se torna uma cidade dormitória né? Isso é interessante. Mas, por outro lado, é uma preocupação muito presente na monitoria né? Nas últimas discussões a gente tem estimulado essa pesquisa de campo nossa, num primeiro momento. Da própria monitoria, por onde vivemos, e depois dos próprios alunos por onde eles vivem. Se nós fazemos pesquisas de campo pra outras cidades, por que não fazermos aqui dentro no próprio DF? Como muitas vezes nós fizemos, né? Enfim, por um lado é uma preocupação, mas na vida prática a gente sabe que não é como nós queríamos. Então (...), pelo menos no meu caso eu não tenho uma experiência com a cidade onde eu moro, mas tenho esse olhar... A preocupação... A partir do Projeto né? (RAFAEL GOMES, Monitor do Re(vi)vendo Êxodos, UnB - Brasília, DF, 04 de novembro de 2014, 15:00h).

Rafael fala deste olhar que tem em relação à cidade onde mora, esta preocupação induzida pelo Re(vi)vendo Êxodos. Mesmo este olhar, sem que dele faça uso prático

\footnotetext{
${ }^{10}$ No Distrito Federal, assim como em muitos grandes Estados do Brasil, os habitantes residem em uma cidade e trabalham em outra. Devido ao trânsito e distância, muitas pessoas, durante os dias úteis, chegam a suas cidades e, consequentemente, a suas casas apenas no horário de dormir, voltando para a cidade onde trabalham no dia seguinte logo após acordar. Considera-se, assim, cidade dormitória, aquela em que o morador não possui tempo para praticar outras atividades além de dormir.
} 
dos espaços da cidade, apenas este olhar possibilita a apreensão da cidade como pertencente ao sujeito.

Pedro Victor explica que mora no Guará, o que é relativamente próximo do Plano Piloto. Sempre que pode procura fazer algo que valorize o lugar onde mora. Plantar mudas de árvores frutíferas em áreas degradadas da cidade é um exemplo. Pedro Victor esclarece, ainda, que não é apenas pela participação no projeto que toma essas decisões, isto também tem relação com seus próprios interesses, mas a participação no projeto lhe permitiu ampliar sua estima em relação à cidade onde mora.

Eu moro relativamente perto daqui do Plano Piloto né? Se eu pegar o ônibus aqui e depois pegar o metrô eu chego em uma hora no Guará. E aí eu moro ao lado ali também da feira, moro ao lado do metrô né? Então, eu acabo voltando lá e... Mas desde que eu comecei a estudar no Setor Leste, desde que eu comecei a me deslocar pro Plano Piloto pra estudar, sacou? Eu perdi o contato com muita gente da minha rua, sendo que isso era uma coisa bem difícil de esconder né? Sendo que eu cresci ali descalço, brincando com um monte de gente, que a gente cresceu junto... Hoje a gente já não... Sei lá! Às vezes a gente nem se fala. Primeiro por que lá no Guará o pessoal expandiu assim, né? Pegou a parte ali da frente, transformou em garagem, botou uma grade, alguns colocaram a cerca né? Elétrica, ou botaram um telhado para tampar mesmo a garagem, pra ninguém ver o que tá acontecendo ali dentro. E aí é isso, todas as casas fazendo isso véi, o pessoal não sabe mais, não conversa mais com vizinho... E muita gente também se mudou, sacou? E agora pra onde foram eu não sei... (...) Mas hoje mesmo, eu peguei umas mudinhas que eu fiz sacou? E fui plantar lá do lado do posto de saúde, tipo frutíferas sabe? (...) Tô tentando ocupar uma área degradada com mudas, ao lado do posto de saúde. (...). É engraçado né?... Por exemplo, ali ao lado tem a feira também do Guará que tem... Que eu geralmente só passava por lá né? Antes ela era aberta e aí eu só caminhava ali quando estava chovendo e eu tinha que passar por dentro da feira. Antes a gente comprava algumas coisas lá, mas eu não vi como é que ela... por que que eu não vivenciei as relações que aconteciam naquela feira ali. Geralmente só nas banquinhas do meio quando o pessoal ia comer. Mas eu sei que hoje lá é um lugar que... Inclusive já voltei lá agora com um colega meu, que ele disse que lá tem o melhor pastel do DF(...) E é isso... Na época que ele trabalhava no Banco do Brasil o pessoal ia ali, descia ali naquela estação, na feira, ia comer ali... É engraçado... Saber que tinham coisas que eu nem tinha noção. Tu acaba não valorizando aonde tu tá ali, mas... Se tu se permitir, tu vê que tem muita coisa acontecendo de legal! (PEDRO VICTOR SOUSA, Monitor do Re(vi)vendo Êxodos, UnB - Brasília, DF, 04 de novembro de 2014, 15:00h).

Compreende-se pelos relatos que, mesmo que desconhecendo esta nomenclatura, os monitores possuem a compreensão em relação ao seu papel como Turista Cidadão e, apesar de passarem menos tempo em suas cidades em relação ao período que dispendem nas cidades onde trabalham e estudam, buscam, na medida do possível, associar o conhecimento que têm com base nas experiências do Re(vi)vendo Êxodos e em suas 
próprias convicções com as práticas vivenciadas em seus locais de residência. Moesch afirma que:

O turista cidadão é aquele morador da localidade que vivencia práticas sociais, no seu tempo rotineiro, dentro de sua cidade, de forma não rotineira, onde é provocado em relação à cidade. Turista cidadão é aquele que resgata a cultura da sua cidade fazendo uso do estranhamento da mesma. Este estranhamento inicia no momento em que o indivíduo descobre no espaço cotidiano outras culturas, outras formas étnicas e outras oportunidades de lazer e entretenimento. Quando se encontra na situação de turista cidadão este sujeito aprende a utilizar os espaços ambientais, culturais, históricos, comerciais e de entretenimento com uma percepção diferenciada do seu cotidiano. (MOESCH, 2005, apud, SALES, 2006).

Diante do conceito de Moesch, cabe retomar a questão das cidades dormitórios. Muitos cidadãos moram em uma cidade e trabalham em outra, como é o caso do monitor Rafael, sendo assim, a cidade onde trabalha se torna, tanto quanto ou mais que a cidade de residência, um ambiente de rotina. Compreende-se, então, que é, também, turista cidadão o sujeito que "vivencia práticas sociais, no seu tempo rotineiro", de forma não rotineira, dentro da cidade onde trabalha ou estuda.

Com base na análise das entrevistas citadas, pode-se compreender como se dá o processo de Educação Patrimonial trabalhado pelo Projeto $\operatorname{Re}(v i) v e n d o$ Êxodos. Identificou-se que este ocorre de forma transdisciplinar agregando elementos essenciais para a formação de Jovens conscientes de seu papel como cidadãos da cidade e do mundo que habitam, tais quais, a cidadania, a ética, cultura, meio ambiente, patrimônio, identidade, entre outros.

Percebe-se pelas falas dos entrevistados que a questão do pertencimento tão prezada e incitada pelo Professor Luís Guilherme, idealizador e co-criador do Re(vi)vendo Êxodos, já está agregada às concepções dos jovens participantes, o que auxiliou e auxilia no processo de descobrimento da identidade por cada um destes indivíduos e na mudança da forma de olhar para as coisas.

Assim se mostra a relação entre o Re(vi)vendo Êxodos, a Cultura, a Educação Patrimonial, o Turismo e a Cidadania: um projeto que educa e conscientiza os jovens ao se colocar como uma ponte entre a teoria aplicada no ensino convencional e a experiência vivida nas pesquisas de campo, na caminhada e em outras práticas coletivas 
propostas pelo Projeto. Por meio da Educação Patrimonial o Projeto Re(vi)vendo Êxodos conscientiza os alunos dos seus direitos como cidadãos, a terem acesso à cultura e ao usufruto da cidade como um ambiente de interação que lhes pertence. Contudo o Re(vi)vendo Êxodos não aborda apenas os direitos, mas também os deveres destes jovens que, igualmente, fazem parte da Cidadania, uma vez que: "o exercício de um direito pressupõe o exercício de outros" (Andrade, 2009, p.1). O Professor Luís Guilherme, sempre que necessário, conforme relatado por Rafael, chama a atenção dos alunos para as atitudes que se mostrem contrárias a cidadania. ${ }^{11}$

\section{6 - Re(vi)vendo a Caminhada}

A caminhada do $\operatorname{Re}($ vi)vendo Êxodos é, provavelmente, a atividade do projeto que causa maior impacto nos alunos. Até o ano de 2014 ocorreram seis edições da caminhada. Foram elas:

1. Brazlândia-DF - Planaltina-DF - Em outubro de 2004: sete dias e 110 $\mathrm{km}$ percorridos ${ }^{12}$;

2. Pirenópolis (Parque dos Pirineus - GO) - Gama (Catetinho-DF) - Em outubro de 2005, dezesseis dias e $340 \mathrm{~km}$ percorridos;

3. Formosa (Marco Zero da Missão Cruls-GO) - Parque Nacional de Brasília (Água Mineral-DF) - Em outubro de 2006, quatorze dias e 310 km percorridos;

4. Chapada Gaúcha (Parque Nacional Grande Sertão Veredas-MG) Jardim Botânico-DF - Em outubro de 2008, quinze dias e $300 \mathrm{~km}$ percorridos a pé, e mais 1.200 feitos de ônibus;

5. Cavalcante-GO - Brazlândia-DF - Em outubro de 2010, quinze dias e $340 \mathrm{~km}$ percorridos a pé, e mais 600 feitos de ônibus.

${ }^{11}$ Vide em ANEXOS o relato do $8^{\circ}$ dia de caminhada que retrata a decepção e tristeza do Professor Luís Guilherme quando um dos alunos faz um comentário inadequado fugindo do contexto da cidadania.

${ }^{12}$ A quilometragem mencionada é percorrida a pé pelos participantes. O grupo se dirige ao ponto de partida de ônibus e volta a pé por todo o percurso passando por roteiros previamente definidos. 
6. Juscelândia/Goianésia-GO - Catetinho/Brasília-DF - Em outubro de 2012, quatorze dias e $260 \mathrm{~km}$ percorridos a pé, e mais 800 feitos de ônibus. ${ }^{13}$.

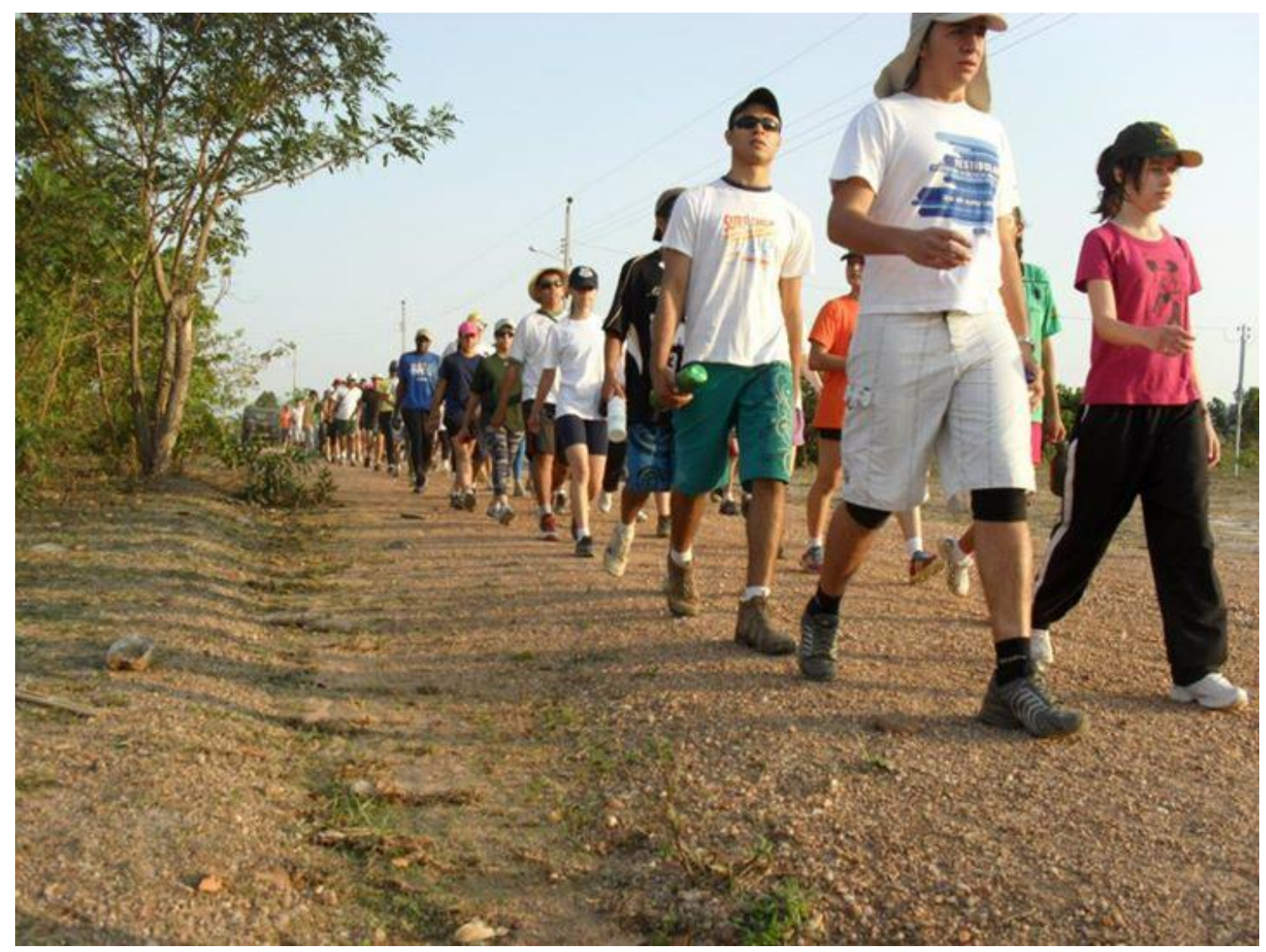

Figura 7: Caminhada Re(vi)vendo Êxodos - Fotografia tirada por monitores do Re(vi)vendo Êxodos, 2010.

O monitor Rafael cita alguns elementos que tornam a caminhada tão especial para os que dela participam e que fazem gerar os sentimentos que ela proporciona:

$\checkmark$ O tempo que a caminhada dura (aproximadamente duas semanas): permite que os participantes possam se conhecer melhor e da maneira mais natural possível, pois as circunstâncias passadas possibilitam que uns estejam próximos aos outros em ocasiões mais naturais, como os momentos de cansaço, dormindo, tomando banho e até na latrina, ou seja, coisas que nas situações cotidianas ninguém sequer pensa sobre o outro.

\footnotetext{
${ }^{13}$ Informações contidas no Release do Projeto Re(vi)vendo Êxodos do ano de 2013, cedido pelo Professor Luís Guilherme juntamente com os demais materiais fornecidos para a pesquisa documental.
} 
$\checkmark$ A situação de desgaste físico, psicológico e sentimental: A caminhada trabalha muito com o físico e, ao mesmo tempo, com o psicológico. É um desafio até mesmo para os monitores que sempre acompanham as caminhadas. No momento da caminhada costumam dizer que ali todos são unidos e todos são iguais perante a poeira da caminhada por onde passam. Neste momento, todos perdem o estereótipo e a vaidade que carregam cotidianamente, este é um momento em que as pessoas se abrem e, talvez por isso, seja um momento de criação de laços muito fortes entre os participantes, por se conhecerem da melhor maneira e, como disse anteriormente, da maneira mais natural possível. As pessoas passam a se admirarem naquelas circunstâncias, pelo que elas realmente são. O desgaste sentimental que relata relaciona-se ao fato de os participantes estarem longe de suas casas, famílias, amigos e, até mesmo, longe de toda zona de conforto, da televisão, do computador, do celular pelos, aproximadamente, 14 dias que duram a caminhada. Contudo, no final das contas, os participantes conseguem perceber que são capazes de viver sem todos esses objetos e, mais do que isso, que são capazes de trocar o computador por uma pessoa, trocar o virtual pelo ser humano. Rafael afirma: "Isso é uma das maiores riquezas".

A questão da troca do virtual pelo ser humano, mencionada por Rafael, é uma experiência de suma importância proporcionada pelo Re(vi)vendo Êxodos, por meio dela os alunos se tornam capazes de compreender o valor das relações pessoais e de construir uma identidade coesa, firmemente fixada e sólida o que, de acordo com Bauman é uma coisa impossível para os indivíduos do "líquido mundo moderno". Desta forma, o Re(vi)vendo Êxodos afasta os jovens, por um período de tempo considerável, da liquidez das relações trazidas pela modernidade e globalização, propiciando experiências individuais e compartilhadas, significativas e duradouras e, ainda, criando e fortalecendo os laços de amizades entre os participantes.

$\checkmark$ Uma constante viagem ao interior de cada um: A caminhada permite uma metamorfose constante. Rafael exemplifica:

(...) no primeiro dia se depara com uma pessoa e observa que ela é da mesma sala que você, mas que nunca conversaram levando-os a 
conversarem pela primeira vez. (RAFAEL GOMES, Monitor do Re(vi)vendo Êxodos, UnB - Brasília, DF, 04 de novembro de 2014, 15:00h).

$\checkmark \boldsymbol{O}$ olhar: Considerado por Rafael o elemento mais importante dentre os citados. O monitor compreende que a caminhada permite que o participante aprenda o olhar além do ver, o sentir além das percepções superficiais dos cinco sentidos, o sentir humano, sentir a natureza. A caminhada sensibiliza todos, alunos, professores e pessoas dos lugares por onde passam, permitindo um compartilhamento muito forte de conhecimento e de sabedoria a partir da experiência e do contato entre os seres humanos.

A partir do relato de Rafael e após diversas declarações e reflexões anteriores nas quais surge a questão do olhar faz-se necessário o seguinte apontamento:

Olhar não é apenas dirigir os olhos para perceber o "real" fora de nós. É, tantas vezes, sinônimo de cuidar, zelar, guardar, ações que trazem o outro para a esfera dos cuidados do sujeito: olhar por uma criança, olhar por um trabalho, olhar por um projeto. (BOSI in NOVAES, 1988, p. 78).

A caminhada, segundo Rafael, promove o exercício do olhar além do perceber, além dos cinco sentidos, o que remete à questão do redimensionamento do olhar que é de extrema importância para a relação que o indivíduo possui com a cidade onde vive e, ainda, é um dos elementos necessários para a formação do Turista Cidadão.

O autor Nelson Brissac Peixoto (1988) afirma que devido à velocidade nos movimentos e informatização à qual a sociedade foi submetida, as cidades passaram a ser vistas por um novo olhar. Tanto o indivíduo passou a olhar para a cidade de forma diferente quanto a cidade passou a corresponder a um novo olhar mediante a alteração de suas formas. A cidade, para o autor, passou por um processo de "superficialização" onde a paisagem urbana se confunde com outdoors, o mundo se converte num cenário e os indivíduos em personagens. Tudo se torna imagem. O autor explica:

Mudanças na estrutura urbana, na arquitetura, nos meios de comunicação e transporte viriam alterar profundamente a própria constituição da realidade. Hoje o real é ele mesmo uma questão. As autopistas de alta velocidade além da informatização - transformam por completo o perfil das grandes cidades e portanto a nossa experiência e nossa maneira de ver. $\mathrm{O}$ indivíduo contemporâneo é em primeiro lugar um passageiro metropolitano: em permanente movimento, cada vez para mais longe, cada vez mais rápido. Esta crescente velocidade determinaria não só o olhar mas sobretudo o modo pelo 
qual a própria cidade, e todas as outras coisas, se apresentam a nós. (PEIXOTO in NOVAES [et al], 1988, p. 361).

O olhar do qual se trata o conceito do Turista Cidadão é a inversão do olhar abordado por Peixoto, ou seja, é o redimensionamento deste olhar afetado pelos meios de comunicação e afins que banaliza e corrompe as imagens da cidade, levando o indivíduo a se colocar de forma observadora e a procurar os locais não afetados por esta banalização e superficialização.

Rafael relaciona, por vezes, a caminhada do $\operatorname{Re}(v i) v e n d o$ Exodos com a própria caminhada da vida, quando se coloca no lugar do outro, é capaz de compreender o quão difícil é a caminhada de cada um. Destaca a importância da união dos grupos durante a caminhada. Se um participante está exausto e já não consegue mais andar naquele momento um monitor, se for preciso, carrega-o no colo, mesmo estando cansado também. Para Rafael é a partir do trabalho em grupo e da valorização dos participantes como seres humanos que aqueles que participam da caminhada retiram forças para conseguir concluí-la. Durante a caminhada não há séries, não há turmas e não há hierarquia. Todos ali são iguais.

Quando chega o momento da caminhada do Re(vi)vendo Êxodos os alunos já estão passando pela formação complementar da qual, durante a entrevista, Rafael sempre cita:

Eu até falo que foi uma formação paralela, na verdade né? Na UnB é uma academia e tal... A gente tem muito de... É... Diferenciar o conhecimento acadêmico do conhecimento popular, do conhecimento... Mais o conhecimento popular da sabedoria né? Eu, particularmente, diferencio muito bem conhecimento e sabedoria. Então, enquanto eu tive uma formação acadêmica na UnB, eu tive uma formação paralela pelo Projeto Re(vi)vendo Exxodos ao longo do mesmo período. Então pra mim foi essencial, né? Eu me sinto... Eu me sinto mais completo. (RAFAEL GOMES, Monitor do Re(vi)vendo Êxodos, UnB - Brasília, DF, 04 de novembro de 2014, 15:00h).

Esta formação complementar que o Projeto oferece é, entre outras coisas, a responsável por instruir os alunos ao exercício da cidadania.

Rafael esclarece que, muitas vezes, os jovens que vão participar pela primeira vez da caminhada começam o percurso pensando em fazer algo pelo próximo nas 
cidades que vão visitar, no entanto, segundo Rafael, o que ocorre é uma aprendizagem mútua.

Caminhantes e moradores trocam experiências promovendo um intercâmbio cultural. A cidadania não é só colocada em prática pelos jovens participantes do Re(vi)vendo Êxodos, mas é, também, identificada por eles nas ações dos moradores das cidades visitadas que os recebem de forma afetuosa e hospitaleira.

Considerando os relatos apresentados, para os jovens participantes do $\operatorname{Re}(v i) v e n d o$ Exxodos, a cidadania é apresentada, inicialmente, como um conceito elaborado em sala de aula. Contudo, ao participarem das atividades práticas do Projeto, inclusive, da caminhada, os alunos percebem nas experiências o sentido de ser cidadão. Com base nos relatos dos alunos dos $2^{\circ}$ e $3^{\circ}$ anos, sobre o que entendem por cidadania, abordados anteriormente, esta toma sentido amplo deixando de ser uma questão de direitos e deveres do indivíduo e passando a representar uma questão coletiva

Percebe-se que uma das diferenças entre as experiências vividas nas pesquisas de campo, mais simples e de curta duração, e a caminhada está na intensidade dos fatos. Durante a caminhada, com o passar dos dias, o cansaço toma o corpo dos participantes que enfrentam intensas situações climáticas e lidam com certas restrições. Estas condições fazem com que a sensibilidade aos momentos se intensifique, sendo assim, a magnitude de cada experiência é maior do que nas demais pesquisas de campo.

Rafael esclarece, ainda, que a caminhada é uma experiência com vários aspectos a serem mencionados e que, por este motivo, não consegue falar sobre tudo que há na caminhada e que, por este mesmo motivo, cada um sente a caminhada de uma forma diferente. Além de cada um ter sua compreensão sobre a caminhada, cada caminhada é diferente da outra, cada caminhada é única.

As pesquisas de campo têm incorporado cada vez mais os valores da caminhada. Segundo Rafael, com o passar do tempo e com o passar das experiências os monitores conseguem observar o que pode ser melhorado no projeto a partir do próprio amadurecimento. Acredita que, por este motivo, o $\operatorname{Re}(v i) v e n d o$ Exxodos é um projeto que está sempre em construção, mesmo tendo 10 anos. 


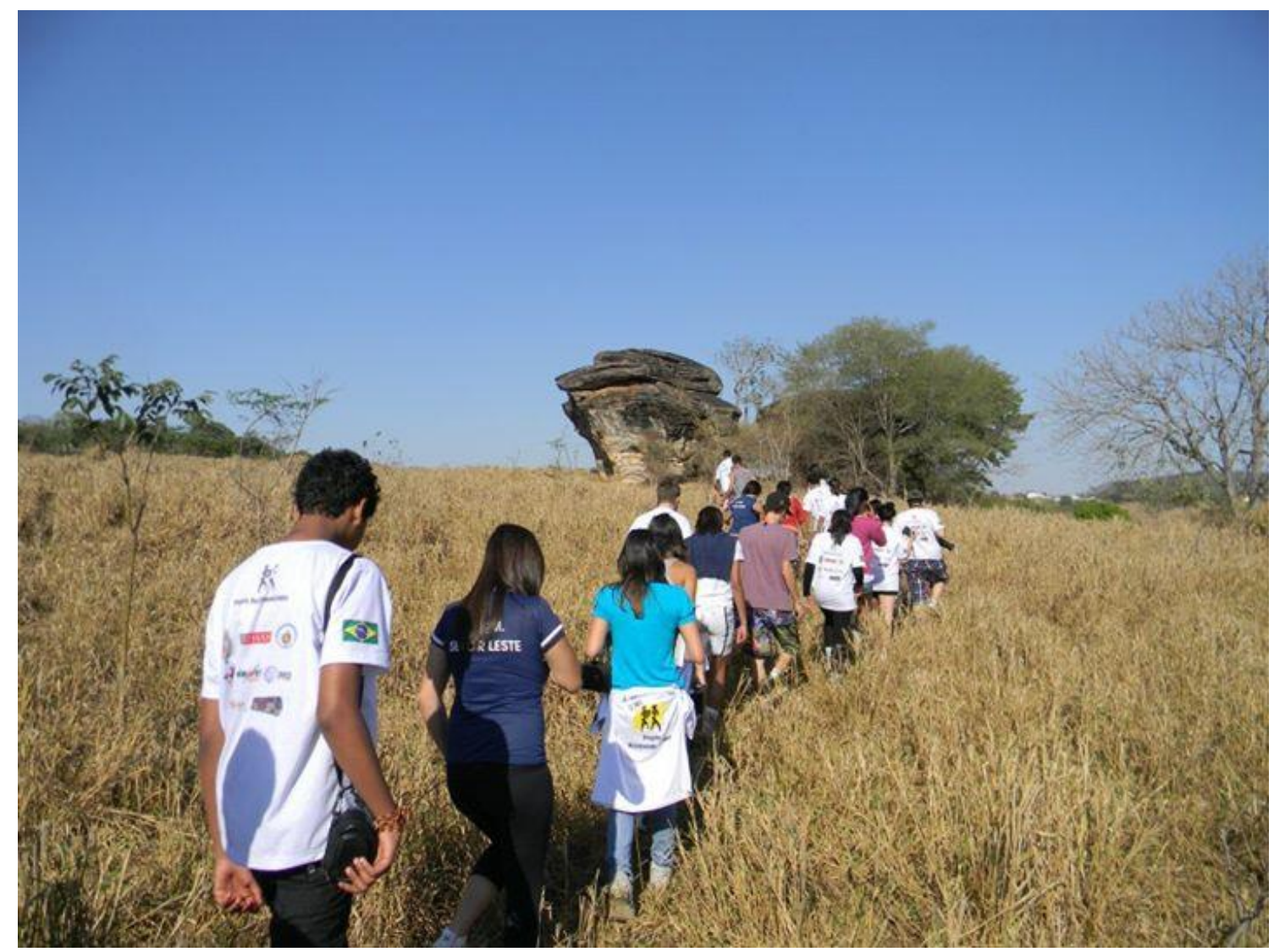

Figura 8: Pesquisa de campo à cidade de Santa Isabel (GO) - Fotografia tirada por monitores do Re(vi)vendo Êxodos, 2011.

Entende-se assim que, por ser flexível às mudanças necessárias, o $\operatorname{Re}(v i) v e n d o$ Êxodos é um projeto que está em constante amadurecimento.

Para a monitora Elizabeth a palavra que define a caminhada é valorização. Para ela o desgaste físico, emocional e psicológico que a caminhada proporciona devido à distância percorrida nas condições climáticas, muitas vezes, desfavoráveis, faz com que o participante aprenda a valorizar coisas pequenas como um copo de água. Exemplifica com a situação de quando um colega está passando mal devido ao calor, porém sua garrafinha de água já está vazia e, neste momento, alguém oferece o pouco de água que resta em sua garrafa. São essas pequenas atitudes que os participantes aprendem a valorizar. Outro exemplo, é de momentos em que fazem muito calor e sol, porém repentinamente surge uma brisa, aquele momento é muito valorizado enquanto se sente a brisa que ameniza o calor.

Para ela estas pequenas situações fazem com que a pessoa passe a se sentir mais sensibilizada em relação ao mundo. Desta forma, ao passarem pelas comunidades durante a caminhada são capazes de valorizá-las, bem como, valorizar suas histórias e a 
história das pessoas que possuem conhecimentos ditos "informais" ("que não precisaram de uma academia para ter conhecimento sobre a floresta ou sobre fazer um doce"). Elizabeth diz:

Os alunos ficam surpresos (...) até eu... Assim, a gente fica um pouco comovido (...) tem mais coisa além da cidade, tem mais coisa além dos livros (...) a caminhada é o estopim do projeto. (ELIZABETH PAZELLO, Monitora do Re(vi)vendo Exxodos, UnB - Brasília, DF, 04 de novembro de 2014, 15:00h).

Elizabeth relembra de um ano que dois alunos deficientes visuais participaram da caminhada e passaram pelas mesmas dificuldades dos demais alunos. Esclarece que estes dois alunos foram grandes exemplos, pois eram os únicos que, mesmo com bolhas nos pés e tomados pelo cansaço como os demais, não reclamavam e permaneciam sempre à frente, demonstrando a vontade de prosseguir. Destaca que essas coisas fazem com que todos se sintam iguais.

Elizabeth relata como se sentiu impressionada ao perceber o poder de percepção que tinham aqueles dois alunos. Afirma que certa vez um deles perguntou à ela se havia uma montanha próxima ao local onde caminhavam, ela respondeu de forma afirmativa e perguntou como ele sabia disso, ele respondeu: "Não tá vindo tanto vento como do outro lado". Elizabeth relata:

Então você fica: "Meu Deus!" Sabe? Como é que pode? Assim, é uma loucura. (...) Caramba! Não sou eu que sou tão observadora assim, sabe? Não sou eu que presto atenção nas coisas... Por que eles também prestam atenção em várias coisas. Não é apenas por eu ver, por eu poder ver, que eu também sei tudo, que eu vejo tudo, que eu sinto tudo. Eles também têm uma capacidade enorme de observar e de sensibilizar com tudo sabe? E eles também falaram que valorizam tudo, a água... Sabe? E querem ajudar e é uma coisa louca que você fica: "Caramba!" (...). Por que que a gente é tão frio, sabe? Por que que a gente vive nesse mundo tão... Sei lá! Doido, que escraviza. É uma coisa louca assim. Eu acho que na caminhada você... Relaxa sabe? Você vê o mundo de uma outra maneira, uma coisa mais crua assim, mais simples mesmo, sabe? (ELIZABETH PAZELLO, Monitora do Re(vi)vendo Exxodos, UnB - Brasília, DF, 04 de novembro de 2014, 15:00h).

Em relação à percepção, relatada por Elizabeth, por parte dos dois alunos deficiente visuais faz-se válida a seguinte afirmação de Bosi:

(...) até mesmo uma filosofia drasticamente emprirista sabe que a coincidência de olhar e conhecer não pode ser absoluta, porque o ser humano dispõe de outros sentidos além da visão: o ouvido, o tato, o paladar e o olfato também recebem informações que o sistema nervoso central analisa e 
interpreta. O vínculo da percepção visual com os estímulos captados pelos outros sentidos é um dos temas fundantes de uma fenomenologia do corpo. $\mathrm{O}$ olhar não está isolado, o olhar está enraizado na corporeidade, enquanto sensibilidade e enquanto motricidade. (BOSI, in NOVAES, 1988, p. 66).

Segundo Elizabeth, as experiências vividas na caminhada também possibilitam que os caminhantes se conheçam verdadeiramente e passem a se gostar por quem realmente são e não pelo que têm. Ao contrário do cotidiano, onde todos olham apenas pra frente devido à correria e imposições do dia-a-dia onde o que mais importa são as aparências e conquistas materiais e não as experiências vividas e compartilhadas, na caminhada os participantes olham para os lados, para quem e o que está à sua volta.

Ao se veem em uma situação onde secador e prancha térmica de cabelo, maquiagem e produções cinematográficas e estereotipadas da aparência não existem, os caminhantes se veem na mesma situação, relaxam e não se sentem retraídos pela aparência natural, vendo à si, aos outros e às coisas de forma mais crua, mais simples.

Por se sentirem mais a vontade e livres em contato com a natureza os alunos dedicam o percurso da caminhada para trocar informações sobre suas histórias de vida, ensinarem o que sabem uns aos outros e aprenderem coisas sobre eles mesmos. Elizabeth ri com o fato de que, ao participarem da caminhada pela primeira vez, os alunos se impressionam com estas pequenas coisas quando, para ela, essas experiências deviam ser o natural e não o raro. 


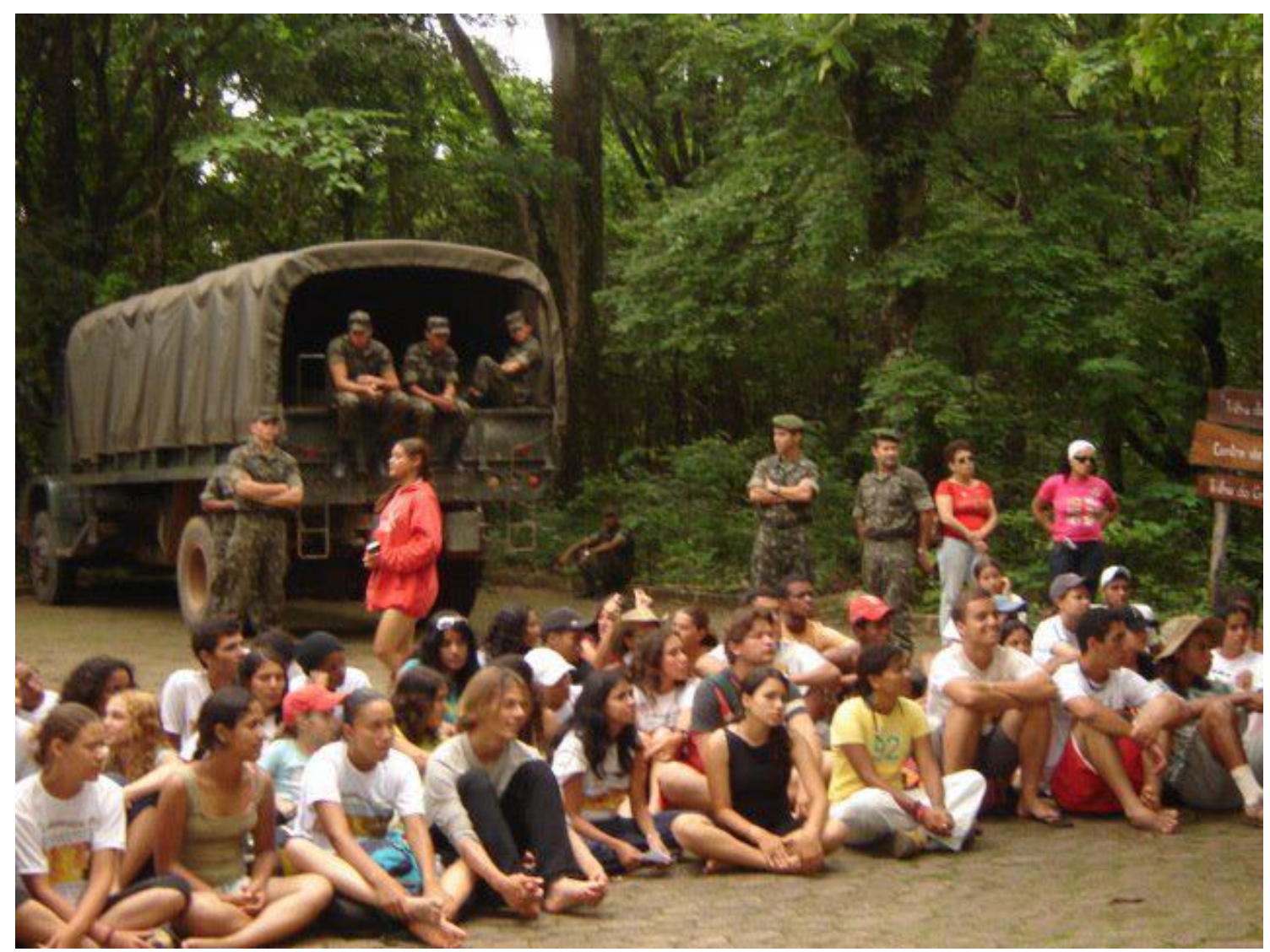

Figura 9: Caminhada Re(vi)vendo Êxodos - Fotografia tirada por monitores do Projeto, 2006.

Para o monitor João Carlos a caminhada é a atividade mais forte do projeto por ser multidimensional. Afirma:

\begin{abstract}
"a caminhada é multidimensional, ela trabalha com a questão psicológica, trabalha com a questão humana, solidariedade, educação, bem estar, comigo, com o próximo (...) é um conjunto de coisas.”. “(...) e ela só é viável, ela só acontece dessa maneira que é pela proposta do caminhar; a gente poderia muito bem passar quinze dias numa cidade de Minas, numa cidade histórica, e ficar ali tendo atividades culturais - que seria maravilhoso também, mas acho que não seria igual à caminhada (...) a caminhada, o fato de você caminhar, esse ato de caminhar, acho que é isso que faz esse projeto ser dessa forma". (JOÃO CARLOS MENDES, Monitor do Re(vi)vendo Êxodos, UnB - Brasília, DF, 04 de novembro de 2014, 15:00h).
\end{abstract}

Para João, se os participantes não caminhassem todo o percurso, as atividades desenvolvidas durante a caminhada não teriam tanto impacto como elas têm.

Ele acredita que a caminhada marca as pessoas por ser uma quebra de modelos e paradigmas, por permitir que os alunos vivam a realidade ao invés de apenas ouvir a realidade contatada na escola. A caminhada, segundo ele, é um processo de aprendizagem do começo até o fim. 
João fala das dificuldades que são enfrentadas para que a caminhada seja concretizada e que, por este motivo, muitas vezes, como no ano de 2014, a caminhada torna-se inviável e acaba não ocorrendo. Alega que, no entanto, são realizadas algumas pesquisas de campo que possuem a mesma intencionalidade da caminhada, porém em menor proporção, ou seja, em menor quantidade de dias. Exemplifica com uma pesquisa feita à Valparaíso de Goiás (cidade localizada no entorno do Distrito Federal), onde os alunos iniciaram o percurso na sexta-feira após o almoço e retornaram no domingo. Nesta pesquisa de campo os alunos passaram por uma reserva ecológica, um viveiro, pela favela de Valparaíso, pela comunidade quilombola Mesquita localizada na Cidade Ocidental (que já existia nesta região antes mesmo da criação de Brasília) e pela cidade Céu Azul. Esta pesquisa impressionou João por ele já ter morado em Valparaíso de Goiás, mas não conhecer nada do que visitou até participar do Projeto Re(vi)vendo Êxodos e ter a oportunidade de participar desta pesquisa de campo.

João afirma que apesar das pesquisas de campo não terem a mesma dimensão da caminhada elas complementam o projeto por terem a mesma intenção de instigar os alunos a terem este olhar diferenciado.

Sobre as pesquisas de campo Elizabeth acredita que elas podem dar aos alunos que não tiveram a oportunidade de participar da caminhada um gostinho do que ela proporciona além de preparar os alunos que dela irão participar.

Em relação às suas experiências com a caminhada, dentre os quatro monitores entrevistados Pedro Victor trouxe o depoimento que mais se divergiu dos demais. Pedro Victor afirma que a caminhada não o impactou de imediato, mas sim, após seu retorno. Relata que, naquele ano, não estava muito comprometido com os estudos e, por este motivo, esta falta de comprometimento foi levada também para a caminhada. Alega que para ele o peso maior da caminhada não foi o cansaço físico. Mesmo tendo que caminhar $30 \mathrm{~km}$ em 6 horas durante os 15 dias da caminhada, isto não foi o mais difícil para ele. Para Pedro Victor o maior desafio era o convívio com as pessoas durante a caminhada, as conversas com os colegas, uma vez que em cada dia da caminhada novas pessoas estavam ao seu lado. Foi uma grande troca de experiências entre diferentes pessoas. A caminhada exigiu dele um comprometimento com todo o grupo, exigiu dele um esforço para mudar a percepção que havia trazido da sala de aula. Contudo, a compreensão sobre o impacto positivo que teve com sua experiência na caminhada veio 
tempos depois de já ter passado por ela quando foi capaz de processar tudo o que vivenciou.

Sobre a experiência de Pedro Victor, João relata que realmente não são todas as pessoas que se magnificam com a caminhada de imediato, pois apesar de ser uma vivência incrível, não é fácil. Para ele, além de cada um ter seu próprio tempo para absorver, a maioria dos alunos sofre um grande impacto em relação a sua maneira de pensar após passar por uma experiência desta grandeza e, além disso, nem todos os alunos estão preparados para vivenciar esta experiência, nem todos tem a capacidade de senti-la e digeri-la. Relata que têm alunos que no primeiro dia já se espantam com a proporção que a caminhada toma e outros só se manifestam no último dia quando percebem que estão chegando ao fim do percurso. Neste sentido há, também, aqueles alunos que só absorvem a experiência que viveram durante a caminhada após voltar à sua rotina normal, uma vez que, o olhar que têm sobre suas atividades cotidianas se tornou completamente diferente de antes.

Pedro Victor ressalta que durante a caminhada ocorrem algumas situações que levam alguns alunos a desviarem o olhar do que realmente a caminhada representa. Além do sol em excesso, o asfalto quente, subidas ou decidas muito íngremes e das bolhas nos pés, alguns alunos se recusam a se alimentar de forma devida: comendo rapadura, bebendo água (nem em excesso, nem em restrição), e tomando um café da manhã reforçado. A falta da alimentação adequada acarreta problemas na pressão e aumenta o cansaço físico. Devido a estas dificuldades alguns alunos acabam concentrando seus pensamentos nestes problemas e se desmotivam não se identificando e não aproveitando a experiência positiva que a caminhada oferece. São em momentos como este que os monitores iniciam canções motivacionais e um colega incentiva e ajuda o outro a prosseguir.

Pedro Victor relembra dos registros que os alunos escrevem durante a caminhada e as pesquisas de campo para historiar suas experiências vividas e descobertas. Ressalta que, certa vez, uma das alunas escreveu em seu registro que a pesquisa que estava fazendo durante a caminhada na realidade era uma "auto-pesquisa". Pedro Victor afirma que gosta de denominar estes registros de relatos, pois acredita ser muito mais importante e relevante o que os alunos escrevem sobre o aprendizado de si e do próximo do que os registros sobre a fauna, flora e paisagem local, uma vez que 
informações deste tipo, apesar de também terem sua importância, já foram registradas por outros pesquisadores. ${ }^{14}$

Pedro Victor considera que é este crescimento e aprendizado em conjunto que faz com que se mantenha como monitor do projeto Re(vi)vendo Êxodos. Para ele os monitores estão criando uma rede onde procuram crescer juntos e compartilhar o conhecimento construído.

João fala que sua permanência no Re(vi)vendo Êxodos se dá por não conhecer nenhum outro projeto tão grandioso quanto este, uma vez que ocorre em escola pública e, ainda assim, consegue desenvolver uma atividade de grande porte levando de 40 a 80 alunos para percorrerem matas e estradas em 15 dias de caminhada, além de enfrentar a dificuldade de ano após ano ter professores antigos sendo desligados do projeto e o desafio de recrutar novos professores interessados. E ainda, ter que conseguir apoios governamentais e institucionais todos os anos para manter o projeto e a realização das atividades que nele estão envolvidas.

A análise realizada aos depoimentos permite compreender que o processo de formação do sujeito turista e do sujeito cidadão no Projeto Re(vi)vendo Êxodos se dá de maneira conjunta. Os alunos, ao mesmo tempo em que realizam atividades práticas que lhes possibilitam o "afastamento simbólico do cotidiano", conforme proposição de Moesch (2004) acerca do Turismo, são estimulados, também, a interagir com os locais e pessoas de maneira cidadã.

Enquanto os monitores relataram suas experiências na caminhada, os alunos dos $2^{\circ}$ e $3^{\circ}$ anos que, até então, não tinham tido a oportunidade de participar desta atividade, explanaram sobre o que pensavam da caminhada. Ao serem questionados se tinham ouvido falar do $\operatorname{Re}(v i) v e n d o$ Exxodos antes de começarem a participar do Projeto Francisco e Hérisson responderam ao mesmo tempo: "Já tinha ouvido falar da caminhada".

Hérisson dando sequência à frase anterior disse:

Mas não sabia do projeto não. (...) Eu só conhecia a caminhada (...) o que eu descobri que era de verdade o projeto, foi só quando eu comecei a participar. (HÉRISSON DUARTE, aluno do $2^{\circ}$ ano, Setor Leste - Brasília DF, 21 de outubro de 2014, 09h30min).

\footnotetext{
${ }^{14}$ Vide em “ANEXOS” alguns exemplos de relatos elaborados na caminhada do ano de 2010.
} 
Eu até fiquei pilhado pra ir esse ano, mas por falta de patrocínio e por algumas outras coisas, eleição, não deu pra fazer. Quando a gente começou a ter aula com o Luís Guilherme também aí a gente começou a entender que era muito maior do que só fazer a caminhada. (FRANCISCO VLADIMIR, aluno do $2^{\circ}$ ano, Setor Leste Brasília, DF, 21 de outubro de 2014, 09h30min).

Sempre que a gente vê alguém com a blusa da caminhada a gente para pra perguntar como foi participar, o que achou! Uma vez a gente encontrou uma pessoa no metrô com a camiseta e aí ele falou que já tinha saído do Setor Leste fazia 3 anos. Perguntou se o Professor Luís Guilherme ainda estava na escola e disse o quanto foi bom ter participado do Exxodos. (HÉRISSON DUARTE, aluno do $2^{\circ}$ ano, Setor Leste - Brasília - DF, 21 de outubro de 2014, 09h30min).

Ao fazer o mesmo questionamento para as alunas do $3^{\circ}$ ano as resposta obtidas também foram a respeito da caminhada:

O primeiro contato que eu tive com o Exxodos foi quando eu tava conversando com uma amiga minha que ela tinha acabado de chegar da caminhada. Então ela ainda tava meio aérea assim do cansaço e aí eu falei: - Eu não vou fazer isso! Não vou! Não vou andar! (...) Mas aí depois que a gente passa realmente a conhecer, aí você se apaixona, é inevitável. (BÁRBARA COSTA, aluna do $3^{\circ}$ ano, Setor Leste - Brasília, DF, 10h30min).

\begin{abstract}
(...) pra ser sincera, um dos motivos que eu entrei no Setor Leste foi o $\hat{E} x o d o s$, por que meu professor de física aqui do $3^{\circ}$ ano, ele é meu vizinho, então eu já conhecia ele desde a sexta série. E aí a gente conversava muito, e aí quando eu cheguei na $8^{a}$ série ele começou a falar do setor leste e tal, como é que funcionava e ele falou do projeto e a minha mãe é psicóloga pedagoga (...) aí a gente gostou muito da ideia do Êxodos e foi um motivo que influenciou eu vir pro Setor. E quando eu cheguei aqui era isso, a gente via o pessoal chegando das caminhadas, das viagens de campo e eu ficava: Caraca, caraca! Nossa! Ano que vem vou fazer isso! (...) Infelizmente ano passado não teve saída de campo. A gente não chegou fazer a caminhada. Por que teve problemas com o bombeiro e com o exército. (...) E esse ano a gente não sabe se vai ter também. Infelizmente. E aí se esse ano não tiver a gente só vai poder ir como monitoras. (JÚLIA OURIQUES, aluna do $3^{\circ}$ ano, Setor Leste - Brasília, DF, 10h30min).
\end{abstract}

Ao questioná-las se tinham interesse em ser monitoras Júlia respondeu:

Se eu não conseguir ir esse ano pra caminhada, com certeza. Eu sempre quis... Eu entrei no Setor Leste por causa da caminhada! Eu tenho que fazer essa caminhada. Mas é bem possível que se eu fizer a caminhada esse ano, eu seja monitora ano que vem e, enfim, eu vou dar um jeito de fazer essa caminhada algum dia na minha vida! (risos). (JÚLIA OURIQUES, aluna do $3^{\circ}$ ano, Setor Leste - Brasília, DF, 10h30min). 
Um vídeo produzido e exibido no site oficial do Sindicato dos Professores do Distrito Federal - Sinpro DF, traz imagens e depoimentos dos participantes da caminhada realizada no ano de 2012 pelo Projeto Re(vi)vendo Êxodos no exato momento em que chegaram ao ponto final da caminhada, o colégio CEM Setor Leste.

Neste vídeo, o professor Acácio, coordenador da caminhada naquele ano, esclarece o percurso realizado pelos caminhantes: Iniciaram pelo município de Juscelândia, passando por Natinópolis, Cirilândia, Goianésia, Pirenópolis, Corumbá, Olhos D’Água, Alexânia, Catetinho com chegada ao Colégio Setor Leste em Brasília. Ao todo foram quase $300 \mathrm{~km}$ percorridos pelos estudantes durante 14 dias. O professor esclarece sobre os alunos:

Caminharam, conheceram outras culturas, conheceram pessoas diferentes, conheceram formas de organização urbana diferentes, formas de organização social diferentes; se enriqueceram, aprenderam muito e hoje com certeza são alunos preparados para superar qualquer obstáculo. (Professor Acácio, Setor Leste - Brasília, DF, 23 de Outubro de 2012).

Giovane, um dos alunos participantes da caminhada, relata:

Lá você tem um contato com a natureza, você aprende a amar, você aprende o valor de um copo de água, você aprende o valor de uma mata, de uma floresta, você aprende o valor de um abraço, você aprende o valor de um bom dia, você aprende o valor de um aperto de mão. (Giovane, Estudante, Setor Leste - Brasília, DF, 23 de Outubro de 2012).

Gabriel Fernando, outro aluno, esclarece:

A caminhada é aprender culturas, é conhecer lugares, conhecer pessoas, conhecer a natureza, ter as aulas ao ar livre, caminhar sem desistir mesmo que o corpo esteja totalmente dolorido. É isso! Não desistir! É o ponto forte da caminhada. (Gabriel, Estudante, Setor Leste - Brasília, DF, 23 de Outubro de 2012).

Karina, também aluna, afirma:

...e esse projeto Re(vi)vendo Exxodos me transformou em uma nova pessoa. (...) A gente entra de um jeito, a gente entra pensando na parte estética, na parte que não tem tanto valor como a gente pensa que tem; a parte mais importante é a parte de dentro. Quando a gente 'tá' andando, caminhando, conhecendo o patrimônio, identidade e meio ambiente, a gente 'tá unido pelo conhecimento, pelo que a gente aprende na caminhada. O mais importante é o que a gente vive! (Karina, Estudante, Setor Leste - Brasília, DF, 23 de Outubro de 2012).

Sara, a quarta aluna que aparece neste vídeo, ressalta: 
Foi uma das melhores experiências da minha vida! Muitas dificuldades, muitas conquistas, muitas derrotas, muitas tristezas, muitas alegrias, (...) foi um projeto de grande superação pra todo mundo! (Sara, Estudante, Setor Leste - Brasília, DF, 23 de Outubro de 2012).

O vídeo é finalizado com os estudantes Giovane e Gabriel Fernando ${ }^{15}$ cantando um dos "gritos de guerra" entoados durante a caminhada que diz:

De um Exxodo Urbano tudo começou, de Juscelândia a Brasília a gente desbravou! - Oh mochileiros do Cerrado o que 'cês' levam aí? - Levamos a coragem e a força pra seguir! (Giovane; Gabriel, Estudantes, Setor Leste Brasília, DF, 23 de Outubro de 2012).

Como mencionado, anteriormente, os depoimentos acima foram registrados no momento em que os alunos retornaram da caminhada para o CEM Setor Leste. Desta forma, os relatos fornecidos são a expressão precisa da experiência a qual os jovens tinham acabado de vivenciar.

Para Gastal:

[...] a identidade se marca no reforço ao que é igual, em contraste com o que seja diferente. $\mathrm{E}$ aqui se poderia retomar o turismo. $\mathrm{O}$ turista, percorrendo outras regiões ou países, tem nesta vivência de semelhanças e diferenças, uma das razões primeiras das suas práticas. (GASTAL, 2006).

As experiências relatadas pelos jovens participantes da caminhada do Re(vi)vendo Êxodos mostram esta "vivência de semelhanças e diferenças" compartilhadas entre si e entre os alunos e os moradores das cidades que percorreram. É a partir destas vivências proporcionadas pelo Re(vi)vendo Êxodos que os alunos começam a construir suas identidades e a se formar em verdadeiros Turistas Cidadãos.

${ }^{15}$ Os alunos Giovani e Gabriel Fernando são os dois participantes deficientes visuais dos quais a monitora Elizabeth mencionou em um de seus depoimentos sobre a caminhada. 


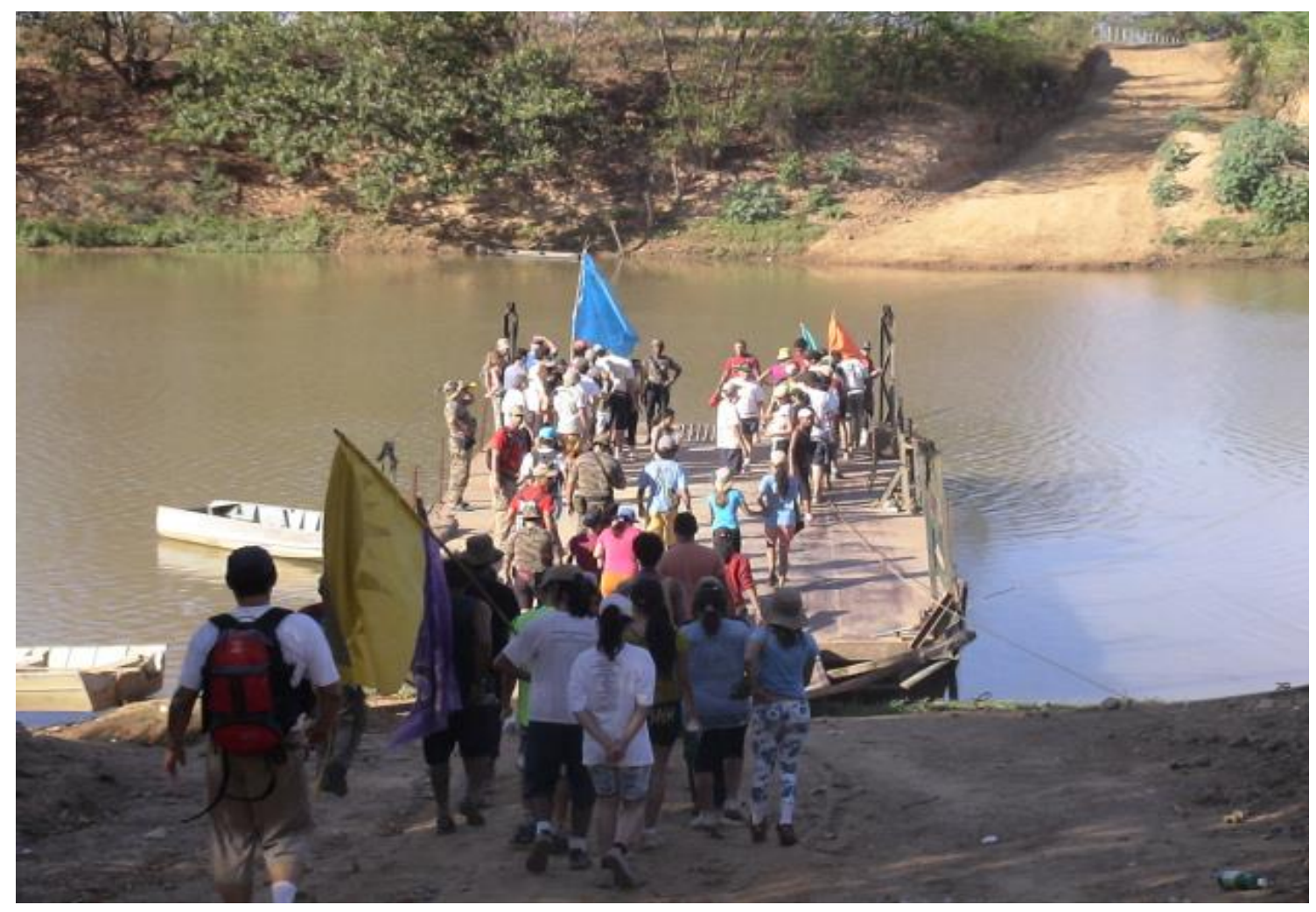

Figura 10: Caminhada - As bandeiras de cores diferentes representam a divisão dos alunos em equipes. Cada equipe é responsável por apresentar um relatório que contenha o registro da "memória" de cada dia da caminhada.

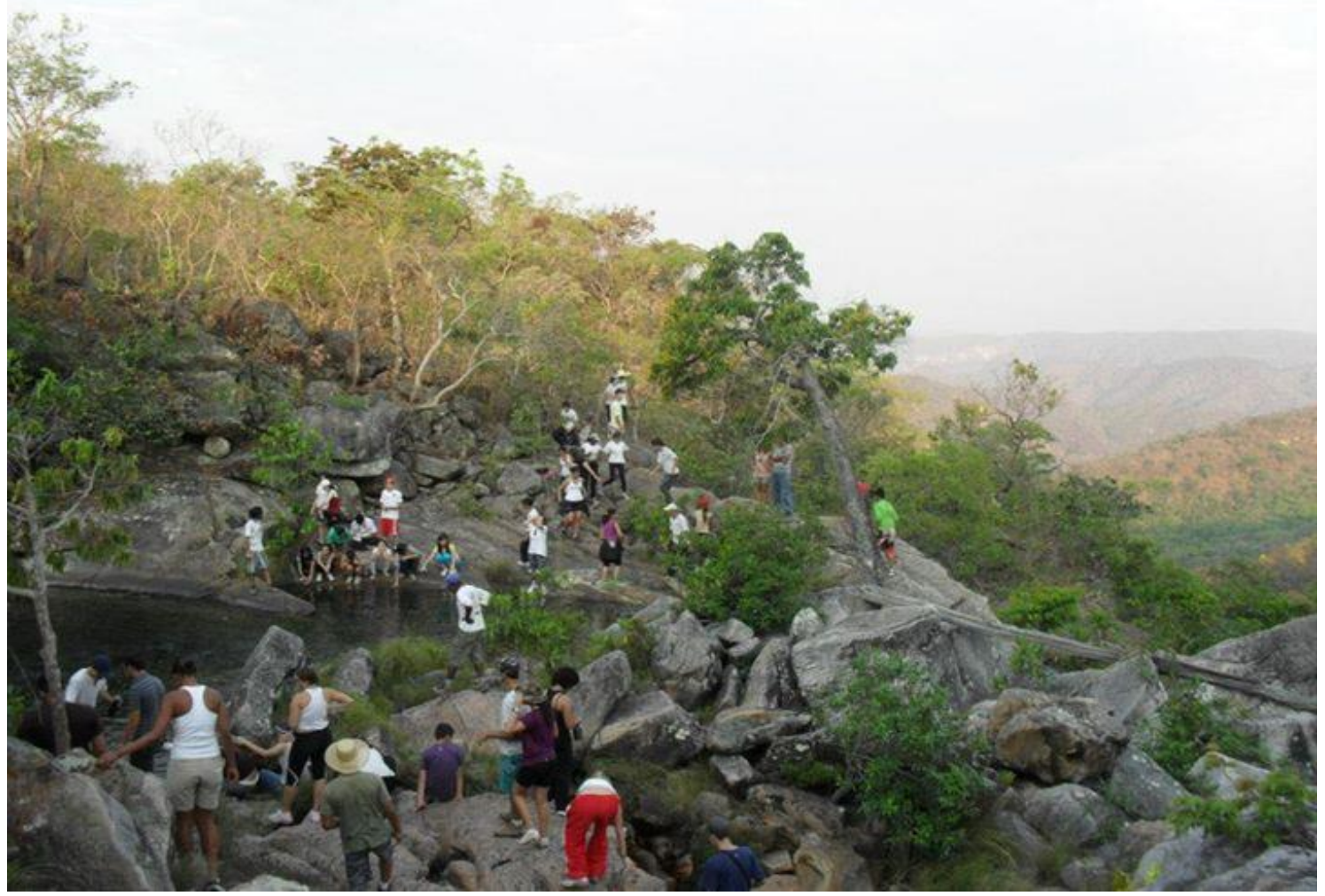

Figura 11: Caminhada 2010 - Fotografias tiradas pelos participantes do Re(vi)vendo Êxodos. 


\section{CONSIDERAÇÕES FINAIS}

A globalização e as avançadas pesquisas e tecnologias têm, segundo Bauman (2004), influenciado nos severos problemas de identidade enfrentados pela sociedade moderna. Os indivíduos vivem as relações de maneira líquida, fluida, sem forma, relações estas que dissolvem e se desfazem com a mesma facilidade que são constituídas. Por este motivo, estes mesmos indivíduos, constroem identidades tão líquidas quanto suas relações. A vida social deixa de ser um conjunto solidamente estruturado pelas crenças, costumes, instituições, ideias e linguagem das quais Dewey (1967) trata, e o que passa a representa-la é a quantidade em detrimento da qualidade.

Dewey (1967) considera que a atividade educativa ocorre com base nos estímulos gerados pelo próprio organismo e pelo meio em que o indivíduo se encontra e que, ainda, são os valores compartilhados dos mais velhos para os mais novos que solidifica a vida social, ou seja, as experiências compartilhadas entre um indivíduo e outro permite que os valores sociais e culturais sejam sustentados.

Freire (2014) considera que uma reflexão crítica deve sempre relacionar a teoria à prática e, também, preza pelo estímulo ao pensamento crítico do educando no processo educativo. Para ele a educação não é um método de transmitir conhecimento, mas sim, um procedimento que estimula o docente a ser criativo numa relação onde educador e educando se educam em processo.

Com base nas perspectivas de Dewey e Freire referentes a educação e considerando que os processos educativos podem servir para auxiliar os indivíduos à direcionarem suas experiências futuras, encontra-se na Educação Patrimonial uma alternativa para a construção sólida da identidade de grupos e indivíduos a partir do reconhecimento dos valores e bens culturais como pertencentes a estes sujeitos.

Ao considerar que, de acordo com Dewey, a experiência faz parte do processo de aquisição de conhecimento, compreende-se que as experiências vividas por meio da Educação Patrimonial, permitem que o indivíduo adquira novos conhecimentos referentes às práticas e conceitos culturais de uma sociedade. A partir destes novos 
conhecimentos adquiridos por meio da experiência, o sujeito tem a possibilidade de integrar uma experiência à outra e um conhecimento ao outro ressignificando suas interpretações.

O Re(vi)vendo Êxodos é um projeto cultural-pedagógico que, por meio da Educação Patrimonial e de atividades culturais, possibilita que os jovens participantes sejam incluídos em experiências socioculturais e turísticas carregadas de significados e que coloquem em prática os conteúdos apreendidos em sala de aula. A análise feita ao Re(vi)vendo Êxodos contou com amplo acervo de arquivos e documentos fornecidos pelo coordenador geral do Projeto, Luís Guilherme, o que auxiliou na elaboração dos roteiros de entrevistas utilizados. Algumas limitações também fizeram parte da pesquisa. O Re(vi)vendo Êxodos passou por algumas dificuldades em relação a patrocínio e apoio durante o ano de 2014, desta forma, algumas das atividades mais importantes não ocorreram neste ano, tais quais, a caminhada e a Mostra de Resultados do final do ano letivo onde ocorre, entre outras exibições de trabalhos, a exposição fotográfica. Por este motivo, algumas análises mais profundas e participativas não puderam ser executadas.

A partir das análises das entrevistas realizadas com os alunos dos $2^{\circ}$ e $3^{\circ}$ anos do Ensino Médio do CEM Setor Leste e com os monitores do Projeto Re(vi)vendo Êxodos confirmou-se a hipótese ponderada inicialmente. Sendo assim, o sujeito que vivencia práticas incentivadas e propostas pela Educação Patrimonial é capaz tanto de apreender dinamicamente, como de praticar o Turismo de forma cidadã.

Esta hipótese se comprova com base nas atividades trabalhas pela Educação Patrimonial abordada pelo $\operatorname{Re}(v i) v e n d o$ Exxodos. As pesquisas de campo e caminhadas permitem que os alunos vivenciem e troquem experiências entre si e os demais participantes do Projeto e, ainda, entre si e os moradores das localidades visitadas. Além da própria Educação Patrimonial os temas cidadania e cultura são abordados nas atividades desenvolvidas pelo Projeto e praticadas pelos jovens, possibilitando que estes compreendam estas questões e, consequentemente, integrem-nas às suas práticas e experiências possibilitando a construção de identidades cambiantes nos sistemas simbólicos a ele apresentado. 
Como objetivo geral proposto, analisou-se em que medida a Educação Patrimonial proposta pelo Projeto Re(vi)vendo Exxodos pode contribuir para a formação do Turista cidadão. Com a pesquisa foi possível verificar que o Projeto trabalha a Educação Patrimonial de forma que envolva os alunos em vários aspectos da cidade, da cultura, da identidade e da sociedade como um todo. As entrevistas realizadas com os alunos dos $2^{\circ}$ e $3^{\circ}$ anos do CEM Setor Leste e, ainda, com os monitores do Projeto Re(vi)vendo Êxodos, pode mostrar as influências positivas que estes jovens sofreram por parte do Re(vi)vendo Êxodos. Em seus relatos os jovens abordam questões relacionadas ao olhar diferenciado que passaram a ter em relação à cidade em que habitam a partir das vivências no Re(vi)vendo Êxodos; relacionaram o significado de Patrimônio às suas experiências relatando que Patrimônio é aquilo que pertence a alguém e que este alguém reconhece este Patrimônio como sendo dele; narraram fatos onde reconheciam a cidadania sendo vivida; relacionaram o conceito de cidadania à qualidade de vida e ao outro, ao coletivo e à ser um membro ativo e crítico da sociedade; relataram como a caminhada ocasionou mudanças em suas vidas, tenham sido estas imediatas ou à longo prazo.

Com base nestes e nos demais relatos apresentados, anteriormente, compreendese que os participantes do Re(vi)vendo Êxodos percebem a importância do Patrimônio para a compreensão da cultura e, sendo assim, para a construção da identidade dos indivíduos, na medida em que essa construção se renova cotidianamente na teia de símbolos aos quais são inseridos a partir das atividades propostas pelo projeto.

Observou-se que existem diferenças nítidas entre os depoimentos dos entrevistados o que demonstra que o processo de formação destes indivíduos por meio da Educação Patrimonial ocorre de maneira progressiva. Sendo assim, as práticas relatadas por uns se mostram mais próximas do conceito de Turista Cidadão do que outros. Contudo, esta divergência é compreensível, uma vez que, os entrevistados participam de diferentes fases do Projeto e que, por este ser um processo contínuo, sempre há possibilidades de se deparar com novos estranhamentos, permitindo experiências novas na construção do Turista Cidadão.

Os resultados apresentados demonstram a necessidade da continuidade da pesquisa no sentido de analisar a viabilidade da implementação da Educação 
Patrimonial correlacionada a outras disciplinas como teoria e prática necessária para a formação de jovens conscientes de seu papel como cidadãos em outras escolas públicas e privadas do Distrito Federal. O Projeto Re(vi)vendo Êxodos é prova de que é possível agregar valores ao ensino regular de forma independente ao currículo escolar que carrega em sua estrutura a padronização formal que limita a docência ao tradicionalismo e rigidez que só é superado por professores capazes de pensar de forma transdisciplinar e aplicar esta transdiciplinaridade de forma independente.

A Educação Patrimonial contribui na área da educação ao tornar os conteúdos tradicionais mais atrativos à aprendizagem e, ainda, ao interferir de forma positiva e construtiva na formação da identidade individual e coletiva. Em se tratando da extensão da teoria e prática da Educação Patrimonial para outras instituições educativas resultaria em um ciclo maior de sujeitos cientes do seu papel como cidadãos o que acarretaria em maior possibilidade de que esta compreensão fosse compartilhada com outros sujeitos por meio da troca de experiências que já ocorrem no cotidiano.

Ao capacitar o indivíduo a pensar de forma cidadã, a Educação Patrimonial se torna, para o Turismo, a chave para a realização de atividades turísticas sustentáveis e criativas. O sujeito dotado da noção de cidadania se apropria dos locais visitados de forma consciente e colaborativa. O "fazer turismo" se torna a busca pelo compartilhamento de experiências, culturas e ideias e, ainda, a busca pelo preservar aquilo que ao sujeito pertence e não por que é tutelado pelo Estado como dever civil e, por este motivo, politicamente correto.

O olhar diferenciado, possibilitado pelas práticas da Educação Patrimonial, permite que o indivíduo aproveite de forma mais profunda o que suas experiências podem oferecer ao compreender a diversidade de atividades, culturas e vivências que existem ocultas nas situações menos esperadas. Neste sentido, encontra-se a viabilidade de se desvendar o inexplorado até nos locais cotidianos ao aproveitá-los de forma insólita em momentos singulares. A partir deste tipo de experiência, o Turista Cidadão carregará em si a possibilidade de percepções profundas nas diversas práticas turísticas, independentemente da distância e durabilidade com que estas ocorram. 


\section{REFERÊNCIAS BIBLIOGRÁFICAS}

AMARAL, M. Nazaré de C. Pacheco. Dewey: Filosofia e Experiência Democrática. São Paulo: Editora Perspectiva S.A, 1990.

ANDRADE, Luciana Teixeira de. Cultura, Cidade e Cidadania. Texto apresentado na II Conferência Municipal de Cultura do município de Belo Horizonte em 17 de outubro de $2009 . \quad$ Disponível em: $<$ http://www.observatoriodasmetropoles.net/index.php?option=com_content $\&$ view=arti cle $\& \mathrm{id}=1191 \% 3$ Acultura-cidade-e-cidadania\&catid $=34 \% 3$ Aartigos\&lang=pt $>$. Acesso em: 05 de novembro de 2014.

ANSARAH, M. G. dos Reis. Formação e capacitação do profissional em turismo e hotelaria: reflexões e cadastro das instituições educacionais no Brasil. São Paulo: Aleph, 2002.

BASTOS, H.F.B.N. Disciplinaridade: multi, inter e trans. Revista Construir Notícias, n'.14, ano3, p.40-41, jan. /fev. 2004. Disponível em: <http://www.construirnoticias.com.br/asp/materia.asp?id=605> Acesso em: 03 de dezembro de 2014.

BAUMAN, Zygmunt. Amor Líquido - sobre a fragilidade dos laços humanos. Rio de Janeiro: Zahar, 2004.

Identidade. Rio de Janeiro: Zahar, 2005.

. Confiança e medo na cidade. Rio de Janeiro: Zahar, 2009.

BENI, Mário Carlos. Análise estrutural do turismo. 9a ed. São Paulo: Ed. Senac, 2003.

BOSI, Alfredo, In NOVAES, Adauto, [et al.]. O Olhar. São Paulo: Companhia das Letras, 1988. 
BRUYNE, Paul de. Dinâmica da pesquisa em ciências sociais. 3 ed. Rio de Janeiro. Ed. Francisco Alves, 1991.

CANCLINI, Nestor Garcia. Culturas Híbridas. São Paulo: Edusp, 1997.

CARVAlHO, José Murilo de. Cidadania no Brasil - O Longo Caminho. $6^{\text {a }}$ ed. Rio de Janeiro: Civilização Brasileira, 2004.

DEWEY, John. Experiencia y educacion. Buenos Aires: Editora Losada, S.A., 1939.

Democracia e Educação - Introdução à Filosofia da Educação. $3^{\text {a }}$ ed. São Paulo: Companhia Editora Nacional, 1959.

Vida e Educação - I. A criança e o programa escolar. II. Interesse e esforço. $6^{\text {a }}$ ed. São Paulo: Comp. Melhoramentos de São Paulo, 1967.

FONSECA, Maria Cecília Londres. Apud: ABREU, Regina; CHAGAS, Mario. Memória e patrimônio: ensaios contemporâneos. 2. Ed. Rio de Janeiro: Lamparina, 2009.

FREIRE, Paulo. Pedagogia do oprimido. $17^{\text {a }}$ ed. Rio de Janeiro: Paz e Terra, 1987.

Pedagogia da autonomia: saberes necessários à prática educativa. $48^{\mathrm{a}}$ ed. Rio de Janeiro: Paz e Terra, 2014.

FUNARI, Pedro Paulo; PINSKY, Jaime (orgs.). Turismo e Patrimônio Cultural. $4^{\text {a }}$ ed. São Paulo: Ed. Contexto, 2009.

GASTAL, Susana. Turismo, Imagens e Imaginários. São Paulo: Aleph, 2005. (Coleção ABC do Turismo).

Turista Cidadão: Uma contribuição ao Estudo da Cidadania no

Brasil. XXIX Congresso Brasileiro de Ciências da Comunicação - UnB; Brasília - DF, 
$<$ http://www.portcom.intercom.org.br/pdfs/15304519080885477710823135712620658

2002.pdf> Acesso em: 02 de fevereiro de 2015. ; MOESCH, Marutschka Martini. Turismo, Políticas Públicas e Cidadania. São Paulo: Ed. Aleph, 2007. (Coleção ABC do Turismo).

IPHAN/PB. Educação Patrimonial: orientação ao professor, Caderno Temático 1. Superintendência do Iphan na Paraíba, João Pessoa, 2011.

HOLANDA, Fabíola; MEIHY, José Carlos Sebe B. História Oral - Como fazer, como pensar. São Paulo: Ed. Contexto, 2007.

KRIPPENDORF, Jost. Sociologia do Turismo: para uma nova compreensão do lazer e das viagens. São Paulo: Ed. Aleph, 2000.

LAVERDI, Robson. História Oral, desigualdades e diferenças. Florianópolis: Ed. Da UFSC, 2012.

LENZI, Teresa. A Cidade Enquanto Paisagem Sociocultural Ucrônica e Utópica: Reflexões a partir de uma poética fotográfica. $3^{\circ}$ Colóquio Ibero-Americano, Belo Horizonte, 2014. Disponível em: <http://www.forumpatrimonio.com.br/paisagem2014/trabalho/329/a-cidade-enquantopaisagem-sociocultural-ucronica-e-utopica-reflexoes-a-partir-a-partir-de-uma-poeticafotografica>.

MANZINE-COVRE, Maria de Lourdes. O que é Cidadania.

MARTINS, José Clerton de Oliveira, organizador. Turismo, Cultura e identidade. São Paulo: Roca, 2003.

MELO, Alessandro de. A construção do objeto turístico: diálogos com a epistemologia de Gaston Bachelard e Pierre Bourdieu. IV SeminTUR, Caxias do Sul, 2006. Disponível em: 
<http://www.ucs.br/ucs/tplSemMenus/eventos/seminarios_semintur/semin_tur_4/gt14> Acesso em: 12 de agosto de 2013.

MERLEAU-PONTY, Maurice. Fenomenologia da Percepção. $2^{a}$ ed. São Paulo: Ed. Livraria Martins Fontes Editora Ltda, 1994.

MOESCH, Marutschka Martini, 2005, apud, SALES, Fabiana de Lima. Patrimônio cultural como insumo para atividade turística e recurso educacional no processo de educação patrimonial: o caso da educação patrimonial no Museu de Caxias do Sul. Dissertação de Mestrado. Caxias do Sul, UCS, 2006.

MOESCH, Marutschka Martini. Epistemologia Social do Turismo. Tese de Doutorado. São Paulo, 2004.

MOLINA, S.; RODRÍGUEZ, S. Planejamento Integral do turismo: um enfoque para a América Latina. Bauru: Edusc, 2001.

MONTEJANO, Jordi. Estrutura do Mercado Turístico. $2^{\text {a }}$ ed. São Paulo: Ed. Roca, 2001.

MORIN, Edgar. Ciência com Consciência. $8^{a}$ ed. Rio de Janeiro: Bertrand, 2005.

Introdução ao pensamento complexo. Trad. Eliane Lisboa. 4 ed. Porto Alegre: Sulina, 2011.

Saberes Globais e Saberes Locais - o olhar transdisciplinar. Rio de Janeiro: Garamond, 2004.

MTUR. Marcos Conceituais. Disponível em: <http://www.turismo.gov.br/export/sites/default/turismo/o_ministerio/publicacoes/down loads_publicacoes/Marcos_Conceituais.pdf> Acesso em 20 de julho de 2013.

NOVAES, Adauto, [et al.]. O Olhar. São Paulo: Companhia das Letras, 1988. 
PAIVA, Maria das Graças de Menezes V. Sociologia do Turismo. Campinas: Ed. Papirus 1995.

PENA-VEGA, Alfredo, [et al.]. Edgar Morin: Ética, cultura e educação. $2^{a}$ ed. São Paulo: Cortez, 2003.

PEIXOTO, Nelson Brissac, In NOVAES, Adauto, [et al.]. O Olhar. São Paulo: Companhia das Letras, 1988.

PROJETO RE(VI)VENDO ÊXODOS - Cidadania, Patrimônio e Qualidade de Vida. Histórico. Disponível em: <http://revivendoexodos2001.wordpress.com/historico/> Acesso em 22 de abril de 2014.

SALES, Fabiana de Lima. Patrimônio cultural como insumo para atividade turística e recurso educacional no processo de educação patrimonial: o caso da educação patrimonial no Museu de Caxias do Sul. Dissertação de Mestrado. Caxias do Sul, UCS, 2006.

SALGADO, Sebastião. Fotografia exposta na Exposição Êxodos. Disponível em: <http://www.amazonasimages.com/travaux-exodes> Acesso em: 10 de fevereiro de 2015.

SENADO FEDERAL. Constituição de 1988. Disponível em: <http://www.senado.gov.br/legislacao/const/con1988/CON1988_05.10.1988/CON1988. pdf> Acesso em: 20 de julho de 2013.

SINPRO DF. TV Sinpro. Caminhada 2012 - Projeto Revivendo Êxodos. Disponível em: < https://www.youtube.com/watch?v=mIIEDGEQbeM> Acesso em: 22 de agosto de 2014.

SUDECO - Superintendência do Desenvolvimento do Centro-Oeste. Municípios pertencentes a RIDE. Disponível em: <http://www.sudeco.gov.br/web/guest/municipios-ride> Acesso em: 18 de fevereiro de 2015. 
THOMPSON, Edward Palmer. A Miséria da Teoria - ou um planetário de erros. Rio de Janeiro: Ed. Zahar Editores S/A, 1981.

A Formação da Classe Operária Inglesa. Rio de Janeiro: Ed. Paz e Terra S/A, 1987.

TORO, Jose Bernardo. A construção do público: cidadania, democracia e participação. Rio de Janeiro: Ed. Senac Rio, 2005.

WESTBROOK, Robert B [et al.]. John Dewey. Recife: Fundação Joaquim Nabuco, Editora Massangana, 2010.

WILliaMS, Raymond. Política do Modernismo - Contra os novos conformistas. São Paulo, Ed. Unesp, 2011. 


\section{APÊNDICE A}

INSTRUMENTO DE PESQUISA I

Roteiro de Entrevista aos Alunos do $2^{\circ}$ ano do Ensino Médio do CEM Setor Leste Participantes do Projeto Re(vi)vendo Êxodos 


\section{Universidade de Brasília \\ Mestrado Profissional em Turismo \\ Instrumento de Pesquisa I}

Roteiro de entrevista aos alunos do $2^{\circ}$ ano do ensino médio do CEM Setor Leste participantes do Projeto Re(vi)vendo Êxodos

1- O que você acha de participar do Re(vi)vendo Êxodos?

2- Antes de participar do projeto você já tinha conhecimento sobre ele? Se sim, qual a percepção que você tinha antes de sua participação?

3- O que mudou desde que você começou a participar do projeto?

4- Qual(s) fator(s) mantém seu interesse em participar do projeto?

5- Como é a relação entre os alunos e os professores do projeto? Difere-se da relação com os demais professores?

6- Quais os pontos positivos de estudar as disciplinas convencionais e participar do projeto ao mesmo tempo?

7- Quais os pontos negativos de estudar as disciplinas convencionais e participar do projeto ao mesmo tempo?

8- Para você, qual o significado de Cidadania?

9- Qual o significado de Qualidade de Vida?

10- Qual o significado de Patrimônio?

11- Qual significado de Identidade?

12- Qual o significado de Meio ambiente?

13- A sua relação com as cidades em que vive e estuda mudou desde que você começou a participar do Re(vi)vendo Êxodos?

14- Qual a sua relação com os monitores do Projeto?

15- Você tem interesse em se tornar um monitor do Projeto após a finalização da sua participação como aluno?

16- Qual(s) a(s) atividade(s) que você mais gostou de participar dentro do projeto?

17- Fale sobre a caminhada do projeto.

18- O que você aprendeu, até o momento, de mais importante com o projeto?

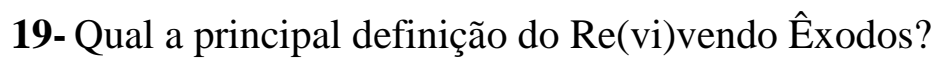

20- Você já tem alguma noção sobre o que fazer após o término do Ensino Médio?

21- O projeto tem alguma relação com essa escolha? 
APÊNDICE B

\section{INSTRUMENTO DE PESQUISA II}

Roteiro de Entrevista aos Alunos do $3^{\circ}$ ano do Ensino Médio do CEM Setor Leste Participantes do Projeto Re(vi)vendo Êxodos 


\section{Universidade de Brasília \\ Mestrado Profissional em Turismo \\ Instrumento de Pesquisa II}

Roteiro de entrevista aos alunos do $3^{\circ}$ ano do ensino médio do CEM Setor Leste participantes do Projeto Re(vi)vendo Êxodos

1- O que você acha de participar do Re(vi)vendo Êxodos?

2- Antes de participar do projeto você já tinha conhecimento sobre ele? Se sim, qual a percepção que você tinha antes de sua participação?

3- O que mudou desde que você começou a participar do projeto?

4- Qual(s) fator(s) mantém seu interesse em participar do projeto?

5- Como é a relação entre os alunos e os professores do projeto? Difere-se da relação com os demais professores?

6- Quais os pontos positivos de estudar as disciplinas convencionais e participar do projeto ao mesmo tempo?

7- Quais os pontos negativos de estudar as disciplinas convencionais e participar do projeto ao mesmo tempo?

8- Para você, qual o significado de Cidadania?

9- Qual o significado de Qualidade de Vida?

10- Qual o significado de Patrimônio?

11- Qual significado de Identidade?

12- Qual o significado de Meio ambiente?

13- A sua relação com as cidades em que vive e estuda mudou desde que você começou a participar do Re(vi)vendo Êxodos?

14- Qual(s) a(s) atividade(s) que você mais gostou de participar dentro do projeto?

15- Fale sobre a caminhada do projeto.

16- O que você aprendeu, até o momento, de mais importante com o projeto?

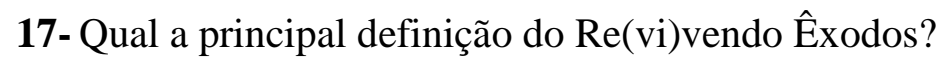

18- Qual a sua relação com os monitores do Projeto?

19- Você tem interesse em se tornar um monitor do Projeto após a finalização da sua participação como aluno?

20- Como você se sente com a proximidade da finalização do Projeto? 
21- Você já tem alguma noção sobre o que fazer após o término do Ensino Médio?

22- O Projeto tem alguma relação com essa escolha? 


\section{APÊNDICE C}

INSTRUMENTO DE PESQUISA III

Roteiro de Entrevista aos Monitores do Projeto Re(vi)vendo Êxodos 
Universidade de Brasília

\section{Mestrado Profissional em Turismo}

Instrumento de Pesquisa III

Roteiro de entrevista aos Monitores do Projeto Re(vi)vendo Êxodos

1- O que você acha de ter participado do Re(vi)vendo Êxodos?

2- Antes de participar do projeto você já tinha conhecimento sobre ele? Se sim, qual a percepção que você tinha antes de sua participação?

3- Faça uma retrospectiva sobre suas experiências desde que começou a participar do projeto?

4- Qual(s) fator(s) mantém seu interesse em participar do projeto (como monitor)?

5- Como é a relação entre os alunos e os professores do projeto?

6- Quais os pontos positivos em ter estudado as disciplinas convencionais e participar do projeto ao mesmo tempo?

7- Quais os pontos negativos em ter estudado as disciplinas convencionais e participar do projeto ao mesmo tempo?

8- Para você, qual o significado de Cidadania?

9- Qual o significado de Qualidade de Vida?

10- Qual o significado de Patrimônio?

11- Qual significado de Identidade?

12- Qual o significado de Meio ambiente?

13- Descreva sua relação atual com as cidades em que vive/estuda/trabalha?

14- Como a participação no Re(vi)vendo Êxodos influenciou nesta relação?

15- Qual(s) a(s) atividade(s) que você mais gostou de participar dentro do projeto?

16- Fale sobre a caminhada do projeto.

17-O que você aprendeu, até o momento, de mais importante com o projeto?

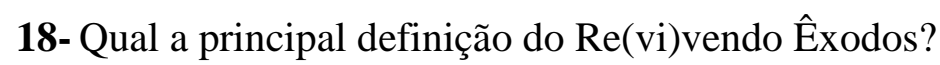

19- Qual a sua relação com os atuais alunos participante do Projeto?

20- $\mathrm{O}$ que você faz atualmente?

21- O projeto teve alguma relação com esta decisão? 


\section{ANEXOS \\ Relatório da Caminhada de Outubro de 2010 da Equipe Verde}




\section{$\underline{\text { Relatório da Equipe Verde }}$}

\section{$1^{\circ} \operatorname{Dia}(04 / 10 / 10)$}

Saímos de Brasília com destino a Comunidade Kalunga, em Cavalcante, que é o maior quilombo brasileiro tombado pelo IPHAN. Vimos a importância que eles dão a natureza, a educação e as pessoas. O Sr. Sirilo, presidente da associação dos moradores, nos mostrou a importância que é dada a cultura local, e como é passada de geração em geração para que seja preservada a identidade da comunidade. Essa valorização da cultura foi percebida por todos nós quando vimos Sirilo falar com 0 maior orgulho de suas origens e seus costumes.

Após a apresentação da comunidade por seus grandes representantes, nós fomos numa cachoeira que é um ponto turistico muito visitado. Foi prazeroso conhecer a comunidade e visitar a cachoeira, que nos proporcionou uma sensação de bem estar muito grande, e também foi muito emocionante observar a alegria das pessoas ao ver uma simples, mas tocante apresentação do exercito brasileiro, que nos acompanha nessa jornada.

\section{$2^{\circ} \mathrm{Dia}(05 / 10 / 10)$}

Começamos nossa $1^{\mathrm{a}}$ caminhada, andamos $27 \mathrm{~km}$, da comunidade Kalunga à cidade de Cavalcante. Nessa caminhada ficou evidente o cansaço e a difículdade que passamos ao caminhar em baixo de um sol escaldante, alguns sem preparo físico e com pessoas desconhecidas.

Mas mesmo assim começamos a perceber o espírito de união que prevalece quando estamos esgotados. À tarde em Cavalcante, tivemos um "aulão" com o Leonardo, chefe do parque Chapada dos Veadeiros, que nos mostrou a atual realidade do parque, cerca de $68 \%$ da preserva queimou o que é equivalente a 48 mil hectares.

Informações rochosas, vegetação, animais e recursos hídricos que só são encontrados no parque foram detonados com as queimadas, o que faz com que o patrimônio biológico ali existente perca alguns de seus atributos.

$\mathrm{Na}$ parte da noite fomos convidados a um evento feito pela prefeitura em comemoração a passagem do projeto re(vi)vendo êxodos pelo município de Cavalcante. Foi uma noite cheia de apresentações e muito animada, ainda não tínhamos a noção da importância do projeto, mas ao chegar em nosso acampamento ouvimos um depoimento muito emocionante do prof ${ }^{\circ}$ Acácio que clareou nossas mentes sobre a importância de estarmos aqui, passando por essas cidades e fazendo história. 


\section{$3^{\circ}$ Dia $(06 / 10 / 10)$}

Saimos de Cavalcante e fomos de ônibus para a fazenda do Coronel Colemar. Inicialmente fomos ao Rio das Almas onde desfrutamos da sua beleza incomensurável e renovamos nossas energias.

Conhecemos o Coronel Colemar, uma pessoa aparentemente simples, mas com uma ambição de querer melhorar o mundo. Com ele vimos os beneficios das queimadas que até então tínhamos em mente como uma coisa muito ruim e aprendemos sobre a enorme capacidade que Goiás tem de crescer em vários aspectos, mas que por conta de políticos com pensamentos arcaicos o desenvolvimento de Goiás fica estagnado. Muitos conhecimentos sobre preservação do meio ambiente foram passados para nós, o que gerou uma mudança em nossas cabeças.

Como as sábias palavras do Coronel, provocaram mudanças, foi proposto aos alunos que fizessem pequenas homenagens a ele na fogueira que foi acesa a noite.

Até então a fogueira foi o momento mais marcante da caminhada, onde surgiram várias manifestações de emoções vividas até o momento e o que mais chamou a atenção do grupo, foi a emoção e a importância que escoteiro Daniel nos passou ao acender o fogo fazendo um ritual que marcou as nossas vidas. Fomos dormir, pois teremos um longo dia.

\section{$4^{\circ}$ Dia $(07 / 10 / 10)$}

Partimos para Alto Paraiso de ônibus porque a estrada estava ruim para a caminhada.

Antes do almoço tivemos uma pequena aula com o Pedro do IPHAN que nos ensinou um pouco sobre fotografia e filmagem, foi quando Milla Petrilo e Geraldo especialistas nas áreas nos acrescentaram com maior amor e entusiasmo algo a mais sobre o tema.

Nesse mesmo dia, depois do almoço, houve uma apresentação de um espetáculo do circo, com uma ex-aluna do projeto, Nayra. Não podemos assistir, pois nesse dia ficamos encarregados de lavar as louças, que foi algo muito divertido onde o grupo teve a oportunidade de se conhecer melhor. Ao terminamos fomos trocar um papo com os Griôs, que são pessoas que passam a diante a cultura falada, foi algo bem legal com poemas lindos e engraçados declamados, e uma filosofia de vida muito interessante do Griô Jaci que nos chamou muita a atenção. Então fomos dormir, porque enfim no outro iamos caminhar. 


\section{$5^{\circ}$ Dia $(08 / 10 / 10)$}

Caminhamos até a comunidade Bandeira, onde foi montado nosso acampamento. Estávamos esgotados.

Vimos o Tenente "matar a cobra e mostrar o pau", depois almoçamos e fomos pra escola Veredas, onde tivemos uma agradável, produtiva, divertida e emocionante tarde com as crianças da escola.

Ficamos encantados com a simplicidade e a inocência das crianças da região, aprendemos a dar valor aos sentimentos e as coisas que temos, pois nesse dia um simples olhar de uma criança tornou a vida de todos que estavam ali mais felizes e humanas.

À noite nós descansamos e na hora do banho o pessoal do exército fez uma brincadeira com todo mundo, o banho foi barulhento porque o Tenente ficava gritando "Sai da minha barraca!", e como tudo é aula, ali aprendemos a trabalhar o nosso psicológico e não ligar com o que os outros falam, se quisermos alcançar o nosso objetivo temos que ter um pensamento forte e naquele dia o objetivo era tomar banho. Fomos dormir, pois a caminhada tinha começado de verdade. 


\section{$6^{\circ} \mathrm{Dia}(09 / 10 / 10)$}

Esse dia nós andamos $26 \mathrm{~km}$ e a estrada era dividida em duas partes. Na $1^{\circ}$ parte era possível ver uma vegetação de árvores altas, diferentes do cerrado e na $2^{\circ}$ era cheio de pastos e ainda com um clima muito quente.

Com isso, percebemos o quanto é ruim caminhar em baixo do sol quente sem ter uma árvore como paisagem, diminuindo a sensação de calor e cansaço, pois estivemos em contato com os dois ambientes e foi possível concluir que as árvores deixam a caminhada mais prazerosa.

Chegamos na fazenda Reunidos do Planalto, mais conhecida como "Fazenda Disbrave", e como de costume, comemos umas laranjas para repor as nossas energias e esperamos um pouco para almoçar como diz nossa mamãe: o almoço está quase pronto! Depois do almoço fomos tomar banho no açude para dar uma relaxada nos músculos e desfrutada da natureza.

$\mathrm{Na}$ parte da tarde, teve um aulão com o gerente da fazenda sobre agronegócio em que tirou todas as nossas dúvidas do tema. A fazenda possui $11 \mathrm{mil}$ cabeças de gado e uma área de 5 mil alqueros, a principal parte da fazenda é o curral onde os gados são vacinados, abatidos e colocados no caminhão para ser transportado, visitamos o confinamento onde fica todos os animais doentes para análise e tratamento.

O melhor tipo de gado para criação é o gado nelore, pois ele se adapta com vários tipos de comidas, fácil de ser manejado e sua carne é bem aceita no mercado, na fazenda de abate somente o bezerro macho tem valor, ao contrário, na fazenda de leite em que a fềmea tem valor.

$\mathrm{O}$ desmatamento é feito de forma controlada pelos engenheiros ambientais. Nos pastos onde não existe eucalipto será plantado para que no tempo de seca, em que muitos gados morrem por causa dela, eles possam ficar na sombra. Isso e muito mais aprendemos em uma tarde bastante proveitosa.

À noite, teve uma reunião com os caminhantes em que podemos partilhar as nossas experiências e trocar idéias, o nosso caro Luiz Guilherme leu uma bela poesia em baixo do sereno, uma cena muito linda e marcante em nossas vidas, então, o professor deu um violão pro Luis e uma mochila pro Luan, que é nossos colegas de caminhada, pois na mesma semana eles foram roubados, todos nos gostamos desse fato por isso decidimos colocar no relatório. Antes de terminar fizemos uma roda, cantamos e dançamos no embalo de uma música indígena que o professor Jorjão ensinou pra gente e depois fomos dormir. 


\section{$7^{\circ} \mathrm{Dia}(10 / 10 / 10)$}

Acordamos cedo, lanchamos e alongamos, então, começamos a caminhar com companhia da professora Solange e Janaína, em uma caminhada com uma vista muito cansativa, pois tinha muitos pastos, passamos por uma mata quase fechada em que foi maravilhoso caminhar em contato com a natureza, mas depois ficou complicado vimos bastantes plantações do tipo de círculos em que gastam muita água, pois boa parte evapora antes de chegar à planta, foi uma das caminhadas mais longa e cansativa, o grupo verde começou a pegar o ritmo de caminhadas, e assim, olhar para a natureza de outra forma com mais amor, sinceridade, respeito, mas não só para a natureza, e sim com o seu próximo.

Chegamos ao destino na escola Ana Maria Moura, onde teve oficinas de teatro, pipa, poesia entre outras. Foi um dos lugares até agora onde podemos ter um contato intenso com a população da região, em que nos explicou um pouco da cultura regional, em particular da caçada da rainha, que foi mantida para homenagear a Rainha Isabel quando ela assinou a Lei Aurea, quando Dom Pedro chegou de Portugal Isabel tinha assinado a Lei, então, ela ficou com medo e fugiu, e Dom Pedro mandou caçá-la, e isso virou tradição, até hoje é feita a caçada a Rainha, segundo a população é algo muito divertido feitos nos quilombos da região. A economia é baseada na agricultura de soja e feijão, e na exploração de minério de manganês. Suas festas típicas são as folias e a festa do Reis. A atividade deu a oportunidade de o grupo conhecer mais sobre região e eles conhecer um pouco da nossa identidade, que também nos foi perguntado, uma verdadeira partilha.

A troca de experiências foi até o anoitecer, e quando acabou, teve uma reunião com o grupo, então, fomos jantar e dormir. 


\section{$8^{\circ} \mathrm{Dia}(11 / 10 / 10)$}

Nós caminhamos $26 \mathrm{~km}$ da Escola Ana Maria de Moura até a cidade de São João D'aliança, onde ficamos "hospedados" nas barracas de feira da cidade. Até então estávamos felizes por poder lavar nossas roupas, por não dormir em barracas, por ter um banheiro, enfim, estávamos quase em casa, quando uma notícia ruim chegou.

O Luiz Guilherme veio gritando querendo reunir todos do projeto, mais um esporro. Pensei que já estávamos acostumados, mas esse era diferente. Foi mais um desabafo do que um esporro foi do fundo da alma. Nós não sabíamos do que se tratava até que ele desmoronou em prantos ao falar que a secretária da cidade não gostou do projeto porque ouviu alguém desprezar a cidade só por não possuir um Banco do Brasil. Nunca tinha acontecido isso, o projeto sempre foi muito bem recebido nas cidades.

Todos que ali estavam presentes puderam ver a dor e a tristeza do Luiz Guilherme manifestadas em choro e raiva. Pois criar um projeto com tanto amor e dedicação para vê-lo ser quase destruído por uma frase dita por alguém que não merecia estar vivendo aqueles dias no projeto é muito ruim. Tão ruim, que depois de ver o Luiz Guilherme daquele jeito, todos nós queríamos dar o melhor de si no contato com a comunidade. Comunidade essa, que não queria receber o projeto, pois as notícias correm e ninguém gosta que fale mal da sua cidade. Depois de ver tamanha tristeza no rosto dos professores, fomos ver uma palestra com o secretário e a secretária de educação de São João D'aliança e mostramos que o projeto respeita a cidade e que a frase dita não corresponde a todos.

Foi uma tarde maravilhosa, todos estavam com um sorriso enorme no rosto e interagiram com a comunidade com muito respeito e dedicação. Ouvimos o secretário e a secretária de educação e depois vimos uma apresentação de quadrilha e assim conseguimos mudar a má impressão do projeto. À noite ouvimos uma música típica da cidade e fomos dormir. 


\section{$9^{\circ} \operatorname{Dia}(12 / 10 / 10)$}

Caminhamos $20 \mathrm{~km}$ numa estrada em que a paisagem maior parte era as plantações em um calor intenso que influenciou muito. E mais uma vez podemos perceber que não a diferença entre rico e pobre, bonito e feio, professor e aluno, somos todos iguais unidos ou não, quando caminhamos unidos a caminhada fica muito fácil, mas quando o individualismo toma conta nada faz sentido e daí sai os comentários: o que eu estou fazendo aqui? Pra que isso? Eu já apredi, quero ir embora! Assim aprendemos que quando estamos unidos e com o pensamento positivo temos uma força inigualável. Chegamos ao posto policial onde acampamos.

Depois do almoço o grupo foi reunido para fazer uma atividade de se orientar através de uma bussola, depois da aula explicando como ela funciona, cada participante do grupo ficou com uma tarefa e cada pessoa tinha sua função que era o líder, o homem ponto, bússola, carta e o burro. 0 grupo teve uma missão que era formar uma frase com 6 senhas.Cada parte da frase e da senhas estavam juntas com o que tínhamos que encontrar.

A partir da primeira pista, tivemos que encontrar os outros destinos. Funcionava assim, primeiro homem bussola achava a direção e mandava o homem ponto correr naquela direção, depois o homem passo ia pelo mesmo caminho que o homem ponto, mas contando os passos para assim termos a distância, e em quanto isso o homem carta anotava a frase e a senha da pista anterior, o homem burro levava os pertences dos companheiros.

Foi uma atividade interessante em que aprendemos a trabalhar em equipe e permanecermos unidos.

E como era o dia da gente, o dia das crianças, depois das atividades comemos pipocas e chupamos pirulitos.

À noite tomamos banho de mangueira, pois a energia acabou onde foi muito marcante que mais uma vez aprendemos a dar valor a tudo que temos, então, fomos dormir. 


\section{$10^{\circ} \mathrm{Dia}(13 / 10 / 10)$}

Foi uma caminhada muito marcante pelo fato do professor Luiz ter caminhado com a gente, mesmo ele indo à frente é outra coisa saber que ele está lá. Com uma vista muito prazerosa, cheia de árvores, córregos, mas o sol estava muito forte e foi preciso o exército mandar o caminhão para nos resgatarmos. Porém, o Luiz não entrou no caminhão continuou caminhando com sua mochila e seu cantil do mesmo jeito que saiu com água. Quando o professor chegou foi algo muito bonito todos os caminhantes 0 receberam com 0 grito de guerra "Se 0 corpo não agüenta, a moral sustenta ", foi mais uma prova de superação e de amor, pelo projeto e por todos nós.

Depois do almoço, fomos para escola estadual povoado do Mato Seco assistir um espetáculo de teatro com a comunidade, eram os Mamulengos Fuzuê, que é passado de geração em geração, é uma cultura popular do Brasil muito engraçada em que todos os caminhantes se divertiram e tiveram mais uma oportunidade de saber o que é ser brasileiro, um sentimento de patriotismo. Teve um aulão com Joe Valle, um dos apoiadores do projeto que nos explicou um pouco sobre desenvolvimento sustentável e agricultura orgânica.

Voltamos a Fazenda Pampeana, tomamos banho e jantamos um belo churrasco, depois se reunimos na fogueira e fomos dormir. 


\section{$11^{\circ} \mathrm{Dia}(14 / 10 / 10)$}

Como todos os dias acordamos as 5:00 horas da manhã com o já acostumado grito de alvorada.Neste dia estava previsto caminharmos em média $32 \mathrm{~km}$, começamos nosso percurso muito animados, presenciamos belas paisagens que só poderiam ser enxergadas numa situação como a nossa, porque por incrivel que pareça as vezes é preciso está em uma situação extrema para realmente poder ver as coisas e as pessoas que estão ao nosso redor e ver o valor delas, isso foi um dos inúmeros aprendizados que obtivemos nesta caminhada. Porém já nos primeiros quilômetros quando o sol ficou mais forte começamos a sentir como a caminhada ia ser difícil, alguns de nós passaram mal, mas o "espírito de corpo" estava presente e estávamos nos ajudando como era possivel, foi uma das caminhadas mais emocionantes não sabemos explicar o porquê exatamente, só sentimos isso. Quando muitos já estavam no seu limite ou chegando, avistamos o caminhão do exercito, de primeiro momento não sabíamos o motivo dele está ali, mas logo veio o prof. Luiz Guilherme nos dizer que o caminhão tinha vindo nos resgatar, pois o sol estava muito quente e ele não via sentido em nos acabar nesta caminhada já que tínhamos outras pela frente o melhor era nos conservar.

Ao chegar ao pouso seguimos com nossa rotina diária, fomos almoçar e depois como nossa equipe estava escalada fomos lavar as louças. Mais tarde fomos para - ginásio que fícava ali perto para ter nosso aulão. Fomos apresentados ao administrador e a alguns professores que contaram um pouco da história de Mato Seco e de sua cultura como as suas lendas mais famosas como a da Eva que foi a que mais nos impressionou pelo fato da professora afirmar que ela existiu e que a família dela ainda mora por lá. Tivemos ainda uma dinâmica com os alunos de lá em que o objetivo era demonstrar como nós caminhantes conseguiamos conviver e nos ajudar tão bem, foi uma experiência divertida e acho que eles também gostaram. Ainda tivemos a oportunidade de conversar com calma com os alunos e moradores de lá e notamos que as opções de lazer e estudo são bem restritas e assim a vontade da maioria é de sair de lá, eles dizem que até gostam de morar lá no povoado mas devido a essas poucas opções a vontade é de estudar em Brasília ou em Goiânia.

Outra coisa que nos chamou a atenção foi a resposta de uma das estudantes quando um de nós perguntou o que eles pensaram quando ficaram sabendo que alunos de Brasília iam para lá, e ela respondeu que imaginava que nós iamos chegar todos "arrumadinhos" que éramos "frescos" "metidos" cheios de besteiras mas ela se surpreendeu ao nos ver chegando todos sujos e suados no caminhão do exército e que naquele momento ela tinha percebido que não éramos assim, contamos como era o projeto e como era nossa vida em Brasília e eles ficaram maravilhados e nos disseram para nossa felicidade que tinham gostado muito daquela tarde, que tinha sido uma experiência única e que não tinha sido nada do que eles imaginaram que seria. Da nossa parte nós realmente amamos poder conversar com eles e ver como é a vida ali. Ainda nos ofereceram uma apresentação de catira e ainda no fim nos ensinaram alguns passos.

No começo da noite fomos para tão esperada aula de sobrevivência com o exército que neste dia contou com outro batalhão que veio especialmente para nos oferecer esta aula. 
Ao chegarmos ao local ficamos impressionados com a decoração do lugar não sabemos se a intenção era nos assustar, mas se era conseguiram. Começamos aprendendo mais sobre os frutos da região assim como identifica-lo como sendo fruto comestivel ou não. Tivemos a oportunidade de experimentar os frutos típicos daquela região e que por sinal eram bem gostosos. Sem contar que alguns de nós teve a experiência de comer um ovo cru com casca, e os que comeram afirmaram que não é tão ruim quanto parece e que para falar a verdade até gostaram. Porém o ponto mais alto da aula foi quando nos ensinaram como matar e fazer sangrar uma galinha e novamente alguns de nós corajosos se ofereceram para matar e tomar o sangue da galinha, já que como disse 0 tenente em situação extrema de sobrevivência tudo tem que ser aproveitado. Por fim nos foi oferecido um "sopão" com vários legumes, frutas e peixe como exemplo do que pode ser feito para comer dependendo das circunstancias. Foi uma aula muito interessante, sobretudo porque podemos aprender na pratica e com certeza foi assim como todas as aulas do projeto um aprendizado para a vida inteira.

Como cada dia do projeto este foi mais um em que aprendemos muito em cada segundo em cada detalhe em cada passo caminhado

\section{$12^{\circ} \mathrm{Dia}(15 / 10 / 10)$}

Ao acordamos, lanchamos e se preparamos para caminhar. Foi uma caminhada moleza para o grupo, pois todos tinham aprendido a caminhar juntos, uma estrada com várias subidas e descidas. E a marcha estava sendo puxada pelo Daniel com outro escoteiro, que vieram somente para nos ajudar, pois nesses últimos dias o perigo estava aumentado, por causa, do cansaço e das partes que tínhamos que caminhar no asfalto que é super perigoso. Quando estávamos chegando à cidade de Mimoso-GO, passamos por almirante magnifico onde podemos apreciar a natureza em $360^{\circ}$.

Depois do almoço, teve uma troca de idéias com os professores da cidade onde foi possivel perceber uma grande desorganização, eles não têm um sindicato ou algo do tipo, para defender seus direitos, sendo assim, verdadeiras marionetes dos politicos.

De noite, teve uma apresentação de catira muito bonita e sincronizada, onde podemos perceber um pouco sobre a cultura, identidade e patrimônio imaterial daquele povo. Ao terminar, fomos todos para as salas de aula dormir. 


\section{$13^{\circ} \mathrm{Dia}(16 / 10 / 10)$}

Uma caminhada perigosa em que grande parte era no asfalto, porém, não aconteceu nada de perigoso com os caminhantes. Chegamos à cidade vibrando, cantando e alegre por ter conseguido mais uma. Limpamos o nosso acampamento, pois estava muito sujo e vimos como é agradável estar em um ambiente limpo e organizado.

A tarde teve uma aulão com as professoras Marilene e Mari, com a contribuição da Eliana. Foi uma aula muito emocionante em teve a terapia do abraço onde podemos perceber que uma coisa tão simples, faz toda diferença. Elas falaram um pouco da história dos deuses gregos, teve um vídeo nos homenageando e uma apresentação de cada grupo para falar o que foi a caminhada. O nosso grupo fez uma frase no cartaz que dizia o seguinte: "A caminhada é curta, mas o aprendizado é longo!", e outro cartaz com palavras que resumia a caminhada, dentre elas amor, companheirismo, união, sinceridade, patriotismo, irmão, superação, fé entre outras. $\mathrm{Na}$ frase o grupo quis dizer que a caminhada é só 15 dias, mas o aprendizado vai ser por toda vida, em cada ação, é um sentimento que incorporamos que vai ficar marcado nos nossos corações.

A noite, jantamos e teve um tempo para fazer os produtos, então, fomos dormir.

\section{$14^{\circ}$ Dia $(17 / 10 / 10)$}

Pegamos um ônibus até a cidade de Brazlândia-DF, ao chegar teve um tempo para terminamos os relatórios, então, teve uma dinâmica com um grande amigo do professor Luiz, onde era preciso muita concentração e atenção, depois fizemos uma roda de ciranda e cantamos várias catingas populares. Foi uma atividade bem descontraída e interessante, pois cada cantiga tinha sua história, uma que o grupo recordou, ela era cantada pra socar o piso da residência, através, da dança e música que tornava algo bem divertido.

Teve também, um aulão com o administrador de Brazlândia onde ele falou sobre violência, a agricultura, turismo, os dados biográficos da cidade entre outros. Um cidadão que deu muita atenção ao projeto e nos incentivou.

Depois do almoço, os caminhantes tiveram a oportunidade de conhecer a cidade, fomos no Santuário Menino Jesus de Praga que é o segundo maior templo católico da América do Sul, então, fomos na lagoa da cidade.

A tarde, todos tiveram a oportunidade de terminar seus produtos, mas como nem tudo é perfeito, à noite o professor viu um cena que o entristeceu bastante e com o grupo reunido, ele partilhou com a gente tamanho descontentamento com os caminhantes. Nesse relatório o grupo verde quer dizer ao Senhor professor Luiz, que todas as preocupações tida com a gente, cada litro de gasolina gastado do seu bolso para correr atrás dos nossos pousos, e assim, acontecer tudo certo, e tudo que o senhor fez com sua equipe valeu muito a pena, tenho certeza por mais que não pareça cada caminhante saiu com uma sementinha de amor, união, superação, patriotismo plantado em seus corações. O nosso muito obrigado a todos vocês! 


\section{$15^{\circ} \mathrm{Dia}(18 / 10 / 10)$}

0 último dia da caminhada. Andamos $19 \mathrm{~km}$ até a fazenda do SINPRO, onde aproveitamos à tarde, pois não tinha aula, tomamos banho na bica, comemos manga e descansamos. Começamos o encerramento da caminhada lá e depois partimos para 0 Setor Leste, onde foram apresentados os produtos da caminhada.

Chegamos ao Setor e os alunos de lá fizeram uma festa ao chegar, alguns pais já tinham chegado para as apresentações dos trabalhos. Foi uma sensação muito gostosa de chegar à casa junto com uma vontade de não ter chegado, de ainda estar caminhando. Fomos para o auditório para serem apresentados os trabalhos: a carta, a música, o vídeo, os sons, a poesia e as artes integradas. Todos que participaram desse final perceberam o quanto essa caminhada foi importante, os depoimentos ao final não deixam dúvidas. Até as pessoas que queriam sair ou reclamavam da caminhada, vão sentir ou já estão sentindo falta de estar todo dia com aquelas pessoas e de estar vivenciando momentos únicos. 